University of Nebraska - Lincoln

DigitalCommons@University of Nebraska - Lincoln

2011

\title{
A review of polymer electrolyte membrane fuel cells: Technology, applications, and needs on fundamental research
}

\author{
Yun Wang \\ The University of California, Irvine, Irvine, CA \\ Ken Chen \\ Sandia National Laboratories Albuquerque, NM \\ Jeffrey Mishler \\ The University of California, Irvine, Irvine, CA \\ Sung Chan Cho \\ The University of California, Irvine, Irvine, CA \\ Xavier Cordobes Adroher \\ The University of California, Irvine, Irvine, CA
}

Follow this and additional works at: https://digitalcommons.unl.edu/usdoepub

Part of the Bioresource and Agricultural Engineering Commons

Wang, Yun; Chen, Ken; Mishler, Jeffrey; Chan Cho, Sung; and Cordobes Adroher, Xavier, "A review of polymer electrolyte membrane fuel cells: Technology, applications, and needs on fundamental research" (2011). US Department of Energy Publications. 132.

https://digitalcommons.unl.edu/usdoepub/132

This Article is brought to you for free and open access by the U.S. Department of Energy at DigitalCommons@University of Nebraska - Lincoln. It has been accepted for inclusion in US Department of Energy Publications by an authorized administrator of DigitalCommons@University of Nebraska - Lincoln. 


\title{
A review of polymer electrolyte membrane fuel cells: Technology, applications, and needs on fundamental research
}

\author{
Yun Wang ${ }^{\mathrm{a}, *}$, Ken S. Chen ${ }^{\mathrm{b}}$, Jeffrey Mishler ${ }^{\mathrm{a}}$, Sung Chan $\mathrm{Cho}^{\mathrm{a}}$, Xavier Cordobes Adroher ${ }^{\mathrm{a}}$

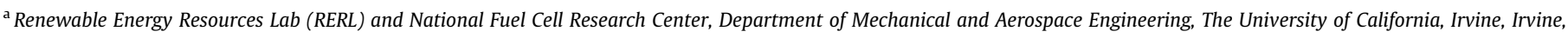 \\ CA 92697-3975, USA \\ ${ }^{\mathrm{b}}$ Engineering Sciences Center, Sandia National Laboratories Albuquerque, NM 87185-0836, USA
}

\section{A R T I C L E I N F O}

\section{Article history:}

Received 3 August 2010

Received in revised form 24 September 2010

Accepted 24 September 2010

\section{Keywords:}

Polymer electrolyte fuel cells

Technology

Application

Fundamental

Review

\begin{abstract}
A B S T R A C T
Polymer electrolyte membrane (PEM) fuel cells, which convert the chemical energy stored in hydrogen fuel directly and efficiently to electrical energy with water as the only byproduct, have the potential to reduce our energy use, pollutant emissions, and dependence on fossil fuels. Great deal of efforts has been made in the past, particularly during the last couple of decades or so, to advance the PEM fuel cell technology and fundamental research. Factors such as durability and cost still remain as the major barriers to fuel cell commercialization. In the past two years, more than $35 \%$ cost reduction has been achieved in fuel cell fabrication, the current status of $\$ 61 / \mathrm{kW}$ (2009) for transportation fuel cell is still over $50 \%$ higher than the target of the US Department of Energy (DOE), i.e. $\$ 30 / \mathrm{kW}$ by 2015 , in order to compete with the conventional technology of internal-combustion engines. In addition, a lifetime of $\sim 2500 \mathrm{~h}$ (for transportation PEM fuel cells) was achieved in 2009, yet still needs to be doubled to meet the DOE's target, i.e. $5000 \mathrm{~h}$. Breakthroughs are urgently needed to overcome these barriers. In this regard, fundamental studies play an important and indeed critical role. Issues such as water and heat management, and new material development remain the focus of fuel-cell performance improvement and cost reduction. Previous reviews mostly focus on one aspect, either a specific fuel cell application or a particular area of fuel cell research. The objective of this review is three folds: (1) to present the latest status of PEM fuel cell technology development and applications in the transportation, stationary, and portable/micro power generation sectors through an overview of the state-of-the-art and most recent technical progress; (2) to describe the need for fundamental research in this field and fill the gap of addressing the role of fundamental research in fuel cell technology; and (3) to outline major challenges in fuel cell technology development and the needs for fundamental research for the near future and prior to fuel cell commercialization.
\end{abstract}

(c) 2010 Elsevier Ltd. All rights reserved.

\section{Contents}

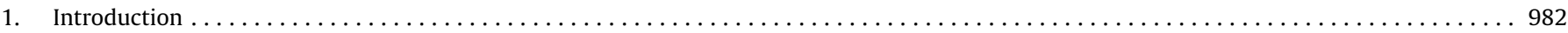

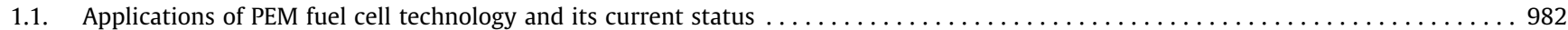

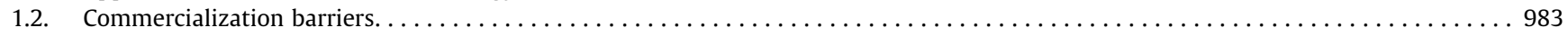

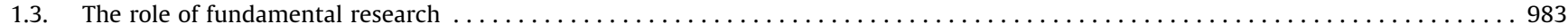

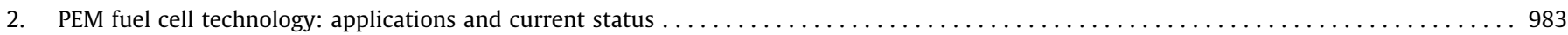

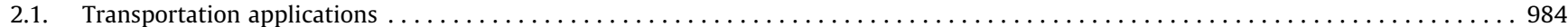

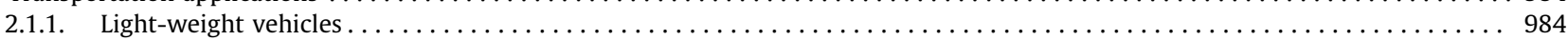

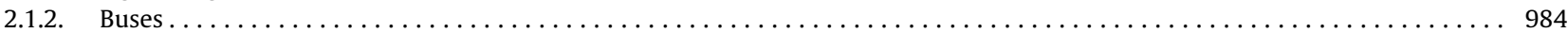

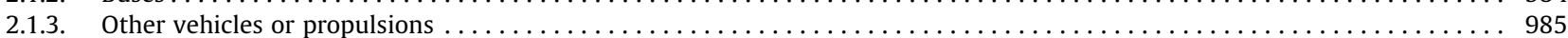

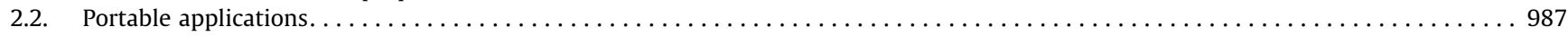

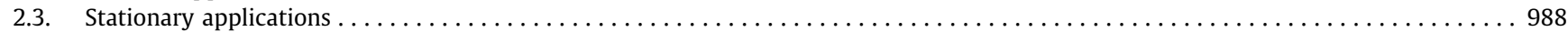

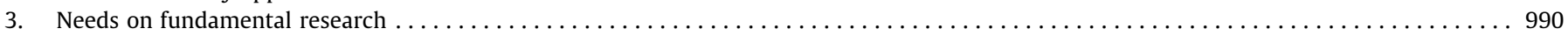

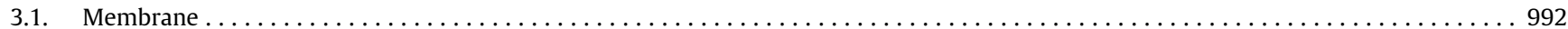

\footnotetext{
* Corresponding author. Tel.: +1 949824 6004; fax: +1 9498248585.

E-mail address: yunw@uci.edu (Y. Wang).
} 


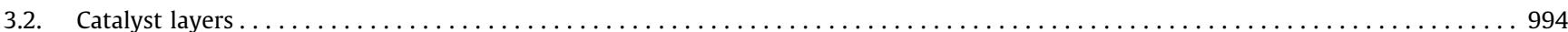

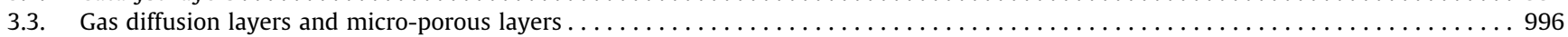

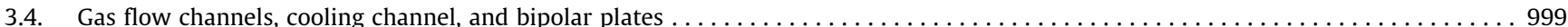

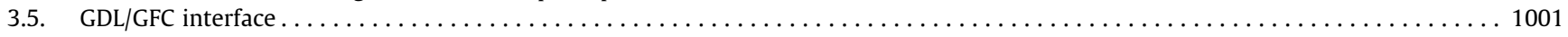

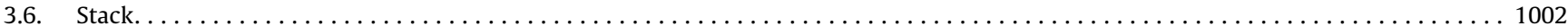

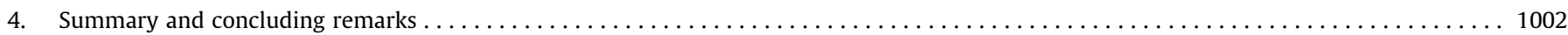

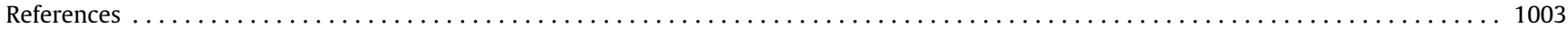

\section{Introduction}

Due to the growing concerns on the depletion of petroleumbased energy resources and climate change, fuel cell technologies have received much attention in recent years owing to their high efficiencies and low emissions. Fuel cells, which are classified according to the electrolyte employed, are electrochemical devices that directly convert chemical energy stored in fuels such as hydrogen to electrical energy. Its efficiency can reach as high as $60 \%$ in electrical energy conversion and overall $80 \%$ in co-generation of electrical and thermal energies with $>90 \%$ reduction in major pollutants [1]. Five categories of fuel cells have received major efforts of research: (1) polymer electrolyte membrane (PEM) fuel cells or PEMFCs (also called PEFCs), (2) solid oxide fuel cells (SOFCs), (3) alkaline fuel cells (AFCs), (4) phosphoric acid fuel cells (PAFCs), and (5) molten carbonate fuel cells (MCFCs). PEM fuel cells are constructed using polymer electrolyte membranes (notably Nafion ${ }^{\circledR}$ ) as proton conductor and Platinum (Pt)-based materials as catalyst. Their noteworthy features include low operating temperature, high power density, and easy scale-up, making PEM fuel cells a promising candidate as the next generation power sources for transportation, stationary, and portable applications. Fig. 1 shows a schematic of a PEM fuel cell.

The very first fuel cell was invented in 1839 by Sir William Robert Grove (an English lawyer turned scientist), though no practical use was found for another century [2]. General Electric Company (GE) began developing fuel cells in the 1950s and was awarded the contract for the Gemini space mission in 1962. The $1 \mathrm{~kW}$ Gemini fuel cell system had a platinum loading of $35 \mathrm{mg} \mathrm{Pt} / \mathrm{cm}^{2}$ and performance of $37 \mathrm{~mA} / \mathrm{cm}^{2}$ at $0.78 \mathrm{~V}$ [3]. In the 1960 s improvements were made by incorporating Teflon in the catalyst layer directly adjacent to the electrolyte, as was done with GE fuel cell at the time. Considerable improvements were made from the early 1970s onward with the adoption of the fully fluorinated Nafion ${ }^{\circledR}$ membrane. However, research and development in PEMFCs did not receive much attention and funding from the federal government, in particular the US Department of Energy (DOE), and industry until a couple of decades ago or so when breakthrough methods for reducing the amount of platinum required for PEMFCs were developed and subsequently improved by Los Alamos National Laboratory (LANL) and others. Notably, Raistrick of LANL came up with a catalyst-ink technique for fabricating the electrodes [4]. This breakthrough method made it possible to increase the utilization of active catalyst and at the same time to reduce the amount of precious platinum metal needed. Though many technical and associated fundamental breakthroughs have been achieved during the last couple of decades, many challenges such as reducing cost and improving durability while maintaining performance remain prior to the commercialization of PEM fuel cells.

In the remaining of this section, the current status of PEM fuel cell technology and applications are first presented, follow by discussions on commercialization barriers and the role of fundamental research.

\subsection{Applications of PEM fuel cell technology and its current status}

The major application of PEM fuel cells focuses on transportation primarily because of their potential impact on the environment, e.g. the control of emission of the green house gases (GHG). Other applications include distributed/stationary and portable power generation. Most major motor companies work solely on PEM fuel cells due to their high power density and excellent dynamic characteristics as compared with other types of fuel cells. Fuel-cell vehicles (FCV) have been developed and demonstrated, e.g. GM Hydrogen 1, Ford Demo Ila (Focus), DaimlerChrysler NeCar4a, Honda FCX-V3, Toyota FCHV, Nissan XTERRA FCV, VW Bora HyMotion, and Hyundai Santa Fe FCV (see Fig. 5a below). Auto makers such as Toyota, Honda, Hyudai, Daimler, and General Motors (GM) have announced plans of commercializing their fuel-cell vehicles by 2015 [5]. Distributed PEM fuel cell power system is primarily focused on small scale (50-250 kW for decentralized use or $<10 \mathrm{~kW}$ for households) [6]. Early design considered fuel cells for residential power supply, in which the waste heat of fuel cells can be utilized for household usage - this significantly increases the overall efficiency [7]. However, the high cost of PEM fuel cells remains a major barrier that prohibits their widespread applications in this area. Back-up power for banks and telecommunication companies receives growing interests recently because of the extremely high cost associated with power breakdowns. Several units like Plug Power GenSys ${ }^{\circledR}$ and Ballard FCgen ${ }^{\mathrm{TM}} 1020$ ACS fuel cell systems have been developed and deployed in many locations. Another promising area is portable power supply, considering that limited energy capacity of batteries unlikely meets the fast-growing energy demand of the modern portable electric devices such as laptops, cell phones and military radio/communication devices. PEM fuel cells provide continuous power as long as hydrogen fuel is available and they can be fabricated in small sizes without

Fig. 1. Schematic of a PEM fuel cell [262]. 
efficiency loss. Major electronics companies, such as Toshiba, Sony, Motorola, LG, and Samsung, have in-house R\&D units for portable fuel cells.

Through the research and development efforts during the past decade, the Pt loading of $\sim 0.3 \mathrm{mg} / \mathrm{cm}^{2}$ has been achieved in many demonstration units. Target set by the US Department of Energy (DOE) is $0.2 \mathrm{mg} / \mathrm{cm}^{2}$ by 2015 , with a corresponding volumetric performance goal of $650 \mathrm{~W} / \mathrm{L}$ [8]. A cost of $\$ 61$ has been achieved in 2009 whereas a lifetime of around $2500 \mathrm{~h}$ was reported for transportation PEM fuel cells. For stationary power generation, a lifetime of $20,000 \mathrm{~h}$ was achieved in 2005. Currently over 200 fuel-cell vehicles, more than 20 fuel-cell buses, and about 60 fuelling stations have operated in the United States Approximately 75,000 fuel cells for stationary power, auxiliary power and specialty vehicles have been shipped worldwide, among them about 24,000 systems were manufactured in 2009 , approximately $40 \%$ increase over 2008 [5].

\subsection{Commercialization barriers}

The world-wide commercialization of PEM fuel cells has not yet come [9-11]. The two greatest barriers are durability and cost [5]. Fuel cell components, such as the MEA (membrane electrode assembly) [12], suffer degradation during long-term operations. The lifetime required by a commercial fuel cell is over 5000 operating hours for light-weight vehicles and over $40,000 \mathrm{~h}$ for stationary power generation with less than a $10 \%$ performance decay $[13,14]$. At current, most fuel cells exhibit major performance decay after around a thousand hours of operation $[13,15,16]$. The DOE targets are to achieve a life time of 40,000 h by 2011 with $40 \%$ efficiency for distributed power and 5000-h durability by 2015 with $60 \%$ efficiency for transportation. Note that $3 \mathrm{M}$ Company recently achieved over $7500 \mathrm{~h}$ of durability for the membrane electrode assembly (MEA) in their single-cell testing at the laboratory level, making it feasible to meet the DOE 2010 target [1]. In past several years, the fuel cell cost has been reduced from $\$ 275$ / $\mathrm{kW}$ in $2002(\$ 108 / \mathrm{kW}$ in 2006 and $\$ 94 / \mathrm{kW}$ in 2007$)$ to $\$ 73 / \mathrm{kW}$ in 2008 , which equates to almost $\$ 6000$ for an $80-\mathrm{kW}$ system, still more than twice as expensive as internal-combustion engine systems [17]. In 2009, the cost was further bought down to $\$ 61 / \mathrm{kW}$ ( $\$ 34 / \mathrm{kW}$ for balance of plant including assembly and testing, and $\$ 27 / \mathrm{kW}$ for stack) and more than $35 \%$ reduction in the last two years. One primary portion of a fuel cell cost is due to the MEA that consists of a Nafion ${ }^{\circledR}$ membrane and catalyst (usually Pt-based) layers [18]. The Pt loading has been reduced by two orders of magnitude in the past decade and there is still room for further loading reduction. The 2010 and 2015 DOE targets for the fuel cell cost is $\$ 45 / \mathrm{kW}$ and $\$ 30 / \mathrm{kW}$, respectively, for transportation applications $[1,17]$. Fig. 2 shows the breakdown of fuel cell cost.

\subsection{The role of fundamental research}

The term "fundamental research" here refers to the knowledgegenerating activities that enable our improved understanding of fuel cell operation principles and engineering of fuel cell technology. Although great efforts have been made with many breakthroughs achieved, another 5-10 years is anticipated being required prior to fuel cell worldwide deployment (the cost and lifetime for current automotive internal-combustion engine power plants are about $\$ 25-\$ 35 / \mathrm{kW}$ and $5000 \mathrm{~h}$, respectively, which are in-line with the DOE 2015 targets) [19]. Various interrelated and complex phenomena occur during fuel cell operation, including mass/heat transfer, electrochemical reactions, and ionic/electronic transport, which govern fuel cell operation. Further scientific breakthroughs are required to overcome barriers related to cost and durability to enable fuel cell commercialization. Breakthroughs in material development, acquisition of fundamental knowledge, and development of analytical models and experimental tools are particularly important for current fuel cell development [5]. For example, avoiding electrode flooding is of critical importance for optimal fuel-cell performance and durability; however this phenomenon is not well understood. The ability to model fuel and reactant transport and electrochemical reactions in electrodes is critical, particularly in the cathode in which the oxygen reduction reaction (ORR) is sluggish and inefficient and water is generated. The fundamental understanding of the electrochemical activity at the triple-phase boundaries is a key to breakthroughs of further Pt-loading reduction.

This review focuses on discussing PEMFC application, technology status, and the needs on fundamental research. Although we attempt to cover the majority of the literature on this topic, there are undoubtedly some that may have been left out. In terms of time frame, this review focuses mainly on the works that have been published through early 2010 .

\section{PEM fuel cell technology: applications and current status}

PEM fuel cells are being applied in the following three areas: transportation, stationary, and portable power generation. The power of electric passenger car, utility vehicles, and bus ranges

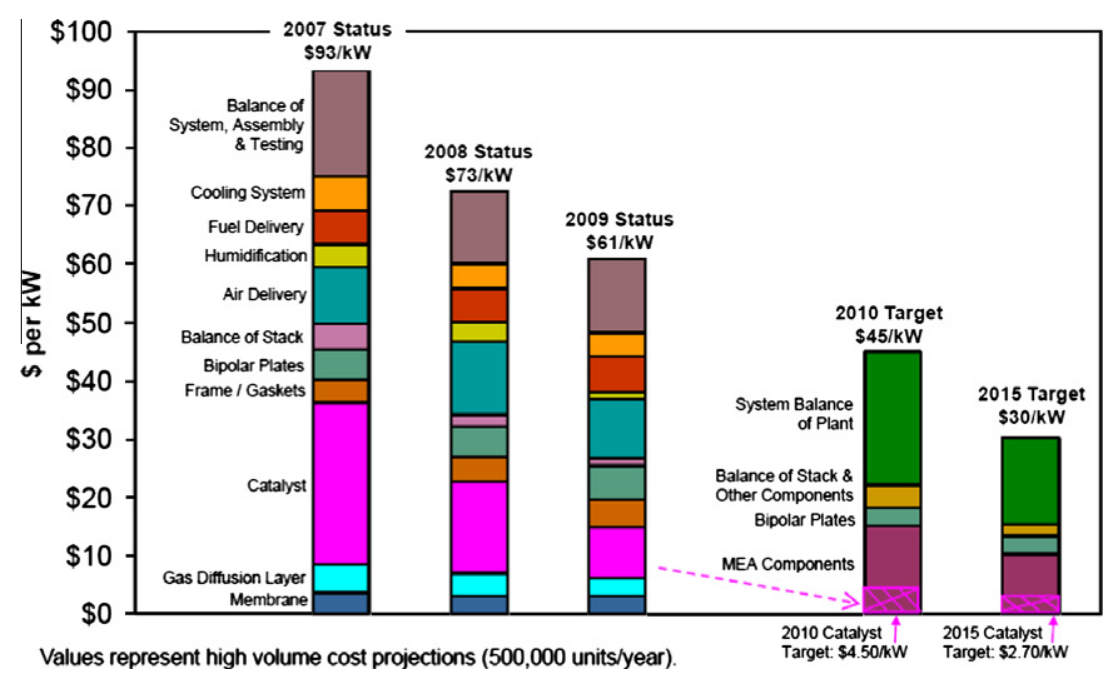

Fig. 2. Fuel cell cost breakdown [1]. 


\section{Shipments by Sector}

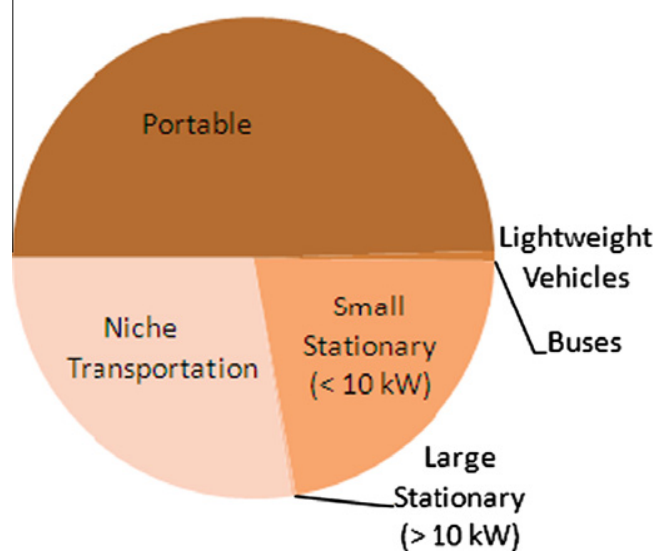

Fig. 3. Number of PEMFC units installed for each applications in 2008 (data from $[26,28,29,39,66,263])$.

from $20 \mathrm{~kW}$ to $250 \mathrm{~kW}$. The stationary power by general fuel cells has a wide range, 1-50 MW. Some small-scale stationary generation, e.g. for the remote telecommunication application, is 100$1 \mathrm{~kW}$ [20]. The portable power is usually in the range of $5-50 \mathrm{~W}$. Fig. 3 displays the portion of PEM fuel cell units installed around the world in each category in 2008.

\subsection{Transportation applications}

Several concerns arise from the global, fast-growing vehicle market, such as air pollution, climate change (due to the greenhouse gases), and fuel sustainability. Most issues are associated with the conventional engines, i.e. ICEs (internal-combustion engines), which primarily depend on hydrocarbon fuels. PEM fuel cells have the potential to replace ICEs due to their potentials of achieving higher efficiency and lower GHG emissions. The typical power range for this type of applications, such as passenger cars, utility vehicles, and buses, ranges from $20 \mathrm{~kW}$ to $250 \mathrm{~kW}$ [20]. Interests in fuel-cell vehicles can be traced back to the late 1970 s and received a major boost in recent years. McNicol et al. reported that PEM fuel cells can be superior to ICEs in several aspects except the initial cost [21]. The technology roadmap published by Ballard Power Systems discussed several main challenges for fuel-cell vehicles: durability, cost and freeze-start [22]. Kazim [23] proposed a scheme with which the United Arab Emirates government can achieve greater economic and environmental benefits associated with the introduction of fuel-cell vehicles.

\subsubsection{Light-weight vehicles}

Fig. 4 shows that the production of regular automobiles increases steadily in early 2000s but becomes fluctuated in recent years.

In the past few years, the fuel cell light-weight vehicle market has been led by Honda, General Motors, and others, see Fig. 5a. Honda has started shipping its FCX Clarity, see Fig. 5b, to Southern and Northern California since these regions are now equipped with hydrogen fuelling stations, where the FCX Clarity is offered to selected customers for a 3-year lease at \$600/month [24]. In 2007 General Motors, through its "Project Driveway" program, delivered over 100 units of its Chevrolet Equinox fuel-cell vehicles to California, Washington DC, and New York, which as of September 2009 had accumulated over 1,000,000 miles of driving [25]. Hyundai-Kia has announced the Kia Borrego SUV. Daimler expects to unveil their new B-Class. Volkswagen is testing several Passat Lingyu, and Toyota continues to produce a small number of its FCHV-adv [26]. Most are being shipped for testing and demonstration in California, which is one of the leading markets for fuel-cell vehicles partly due to its stringent Zero Emission Vehicle (ZEV) regulations and existing hydrogen fuelling infrastructure. Table 1 documents the key parameters of several fuel-cell vehicles.

\subsubsection{Buses}

Fig. 6 shows the number of fuel-cell buses commercialized each year from 1994 through 2008. Several government-funded procurement plans were announced recently, such as the US National Fuel Cell Bus Program and Europe's Fuel Cell and Hydrogen Joint Technology Initiative. The number is expected to increase in the near future.

In Fig. 6, the peak in 2003 corresponds to Daimler's introduction of its 33-bus fleet for the European CUTE (Clean Urban Transport for Europe) and ECTOS (Ecological City TranspOrt System) and Australian STEP (Sustainable Transport Energy Project) programs (Fig. 7) and (Table 2). In the CUTE program each participating city has different buses. Stockholm runs the Mercedes-Benz Citaro fuelcell buses, each has two fuel cell stacks with a total power of $250 \mathrm{~kW}$ and $40 \mathrm{~kg}$ hydrogen stored at 350 bar that provides fuel for about $200 \mathrm{~km}$ operation [27]. It is indicated that at low-power

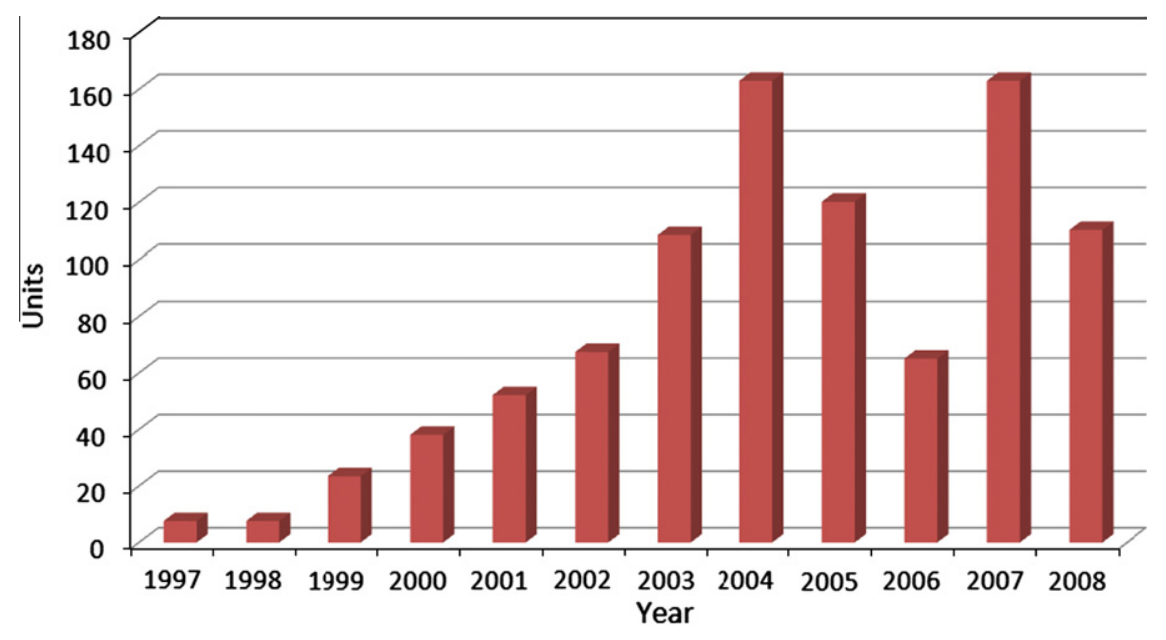

Fig. 4. Number of fuel cell-powered automobiles manufactured [26]. 
(a)
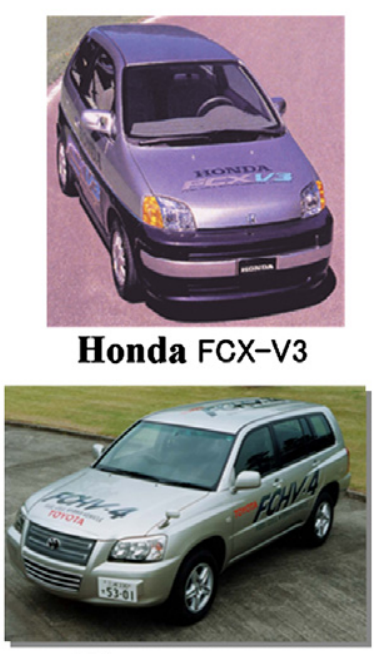

Toyota FCHV-4

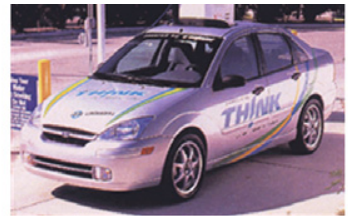

Ford Demo IIa (Focus)

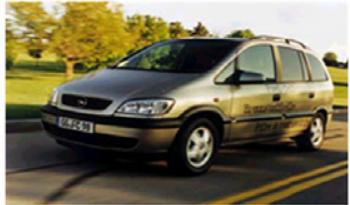

GM Hydrogen 1 (Zafira)

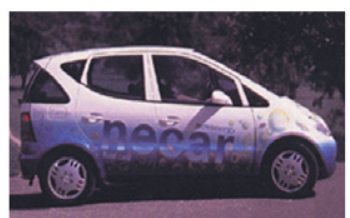

DaimlerChrysler NeCar4a

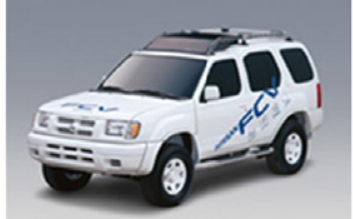

Nissan XTERRA FCV

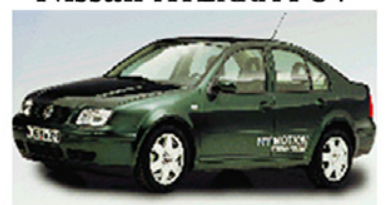

VW Bora HyMotion

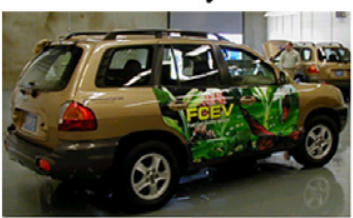

Hyundai Santa Fe FCV

\section{(b)}

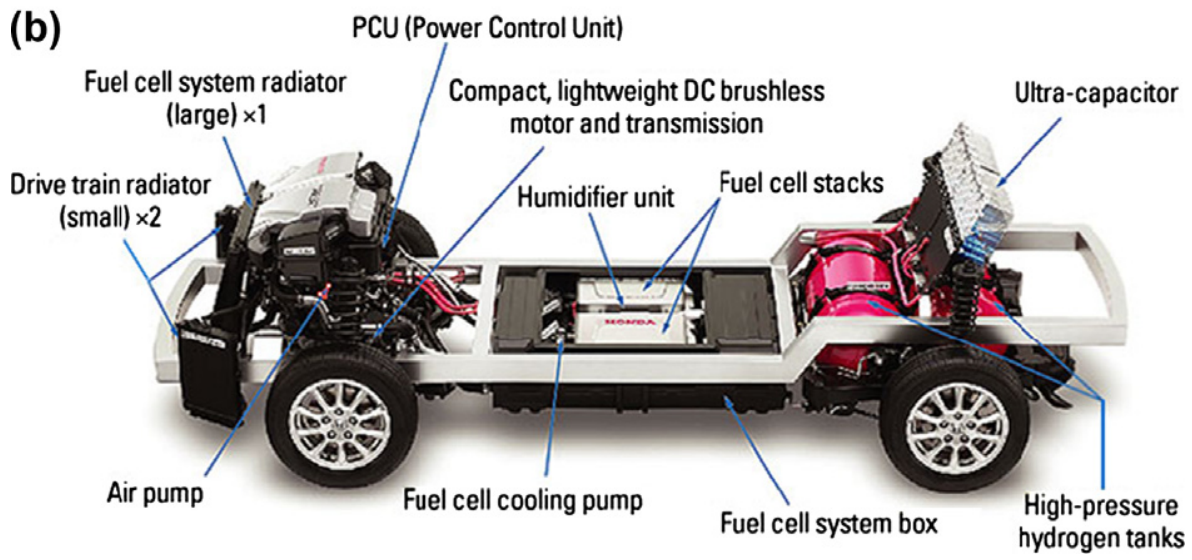

Fig. 5. Fuel cell vehicles by various automakers [264] (a) and layout of the Honda FCX Powertrain [265] (b).

Table 1

Specifications of several fuel-cell vehicles [265,286-293] (for a more complete listing of fuel-cell vehicles, see Ref. [294]).

\begin{tabular}{|c|c|c|c|c|c|}
\hline Vehicle name & Type & Year & Power (kW) & Hydrogen storage and capacity & Driving range \\
\hline Honda FCX-V3 & Compact Car & 2000 & 60 & $100 \mathrm{~L}$ at $250 \mathrm{~atm}$ & $180 \mathrm{~km}$ \\
\hline Honda FCX-V4 & Compact Car & 2002 & 60 & $137 \mathrm{~L}$ at $350 \mathrm{~atm}$ & $315 \mathrm{~km}$ \\
\hline Honda FCX 2nd Generation & Compact Car & 2004 & 80 & $156.6 \mathrm{~L}$ at $350 \mathrm{~atm}$ & $430 \mathrm{~km}$ \\
\hline Honda FCX Clarity FCEV & Compact Car & 2007 & 100 & $3.92 \mathrm{~kg}$ at $5000 \mathrm{psi}$ & 240 miles \\
\hline Chevrolet HydroGen3 & Minivan & 2001 & 60 & $3.1 \mathrm{~kg}$ at $700 \mathrm{bar} / 4.6 \mathrm{~kg}$ at $-253^{\circ} \mathrm{C}$ & $270 \mathrm{~km} / 400 \mathrm{~km}$ \\
\hline Chevrolet Sequel & Cross-over SUV & 2005 & 73 & $8 \mathrm{~kg}$ at $700 \mathrm{bar}$ & 300 miles \\
\hline Chevrolet Equinox FCV & Sport utility vehicle & 2008 & 93 & $4.2 \mathrm{~kg}$ at $700 \mathrm{bar}$ & 200 miles \\
\hline Toyota FCHV & Sport utility vehicle & 2001 & 90 & 350 bar & 180 miles \\
\hline Toyota FCHV & Sport utility vehicle & 2005 & 90 & 350 bar & 200 miles \\
\hline Toyota FCHV-adv & Sport utility vehicle & 2009 & 90 & $156 \mathrm{~L}$ at $700 \mathrm{bar}$ & 430 miles \\
\hline Kia Borrego & Sport utility vehicle & 2009 & 109 & - & 426 miles \\
\hline Daimler B-Class & Compact car & 2009 & 100 & 700 bar & $400 \mathrm{~km}$ \\
\hline Passat LingYu & Sedan & 2008 & 55 & - & 186 miles \\
\hline
\end{tabular}

(under $40 \mathrm{~kW}$ ) operation the fuel cell stack efficiency is over 65\% based on the lower heat value (LHV).

Due to the CUTE and similar programs, over half of the commercialized fuel-cell buses are running in Europe, a quarter in Asia, and $15 \%$ in North America. In North America, California is the main region of fuel cell bus activity, primarily due to the ZEV regulation approved by the California Air Resources Board (CARB) [28].

\subsubsection{Other vehicles or propulsions}

In addition to buses and light-weight automobiles, PEM fuel cells may be employed in several other applications within the transportation/propulsion sector. These applications include electric powered bicycles, material handling vehicles such as forklifts, and auxiliary power units (APUs) including leisure, trucking, marine and Unmanned Aerial Vehicles (UAVs) [29]. Hwang et al. [30] 


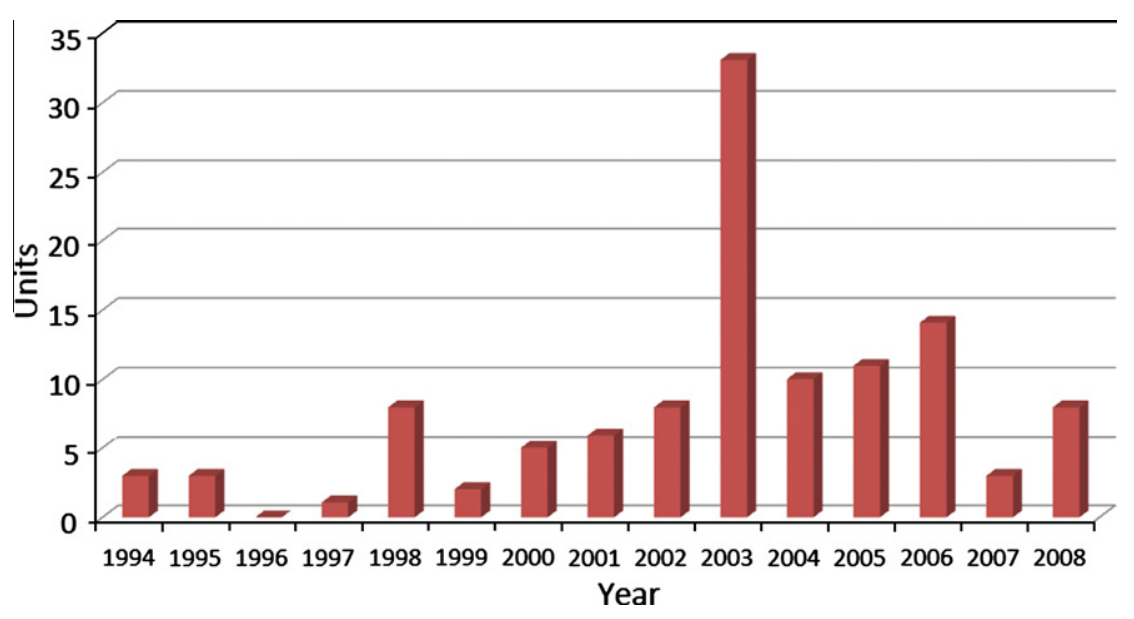

Fig. 6. Number of PEM fuel cell-powered buses commercialized [28].
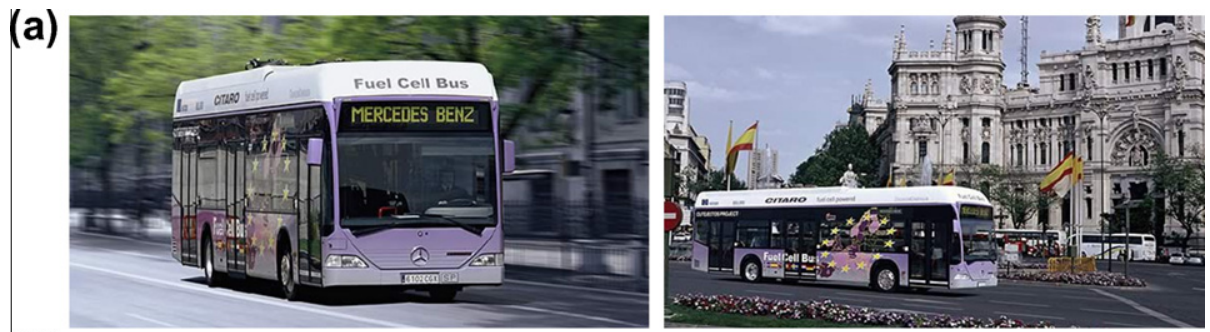

(b)

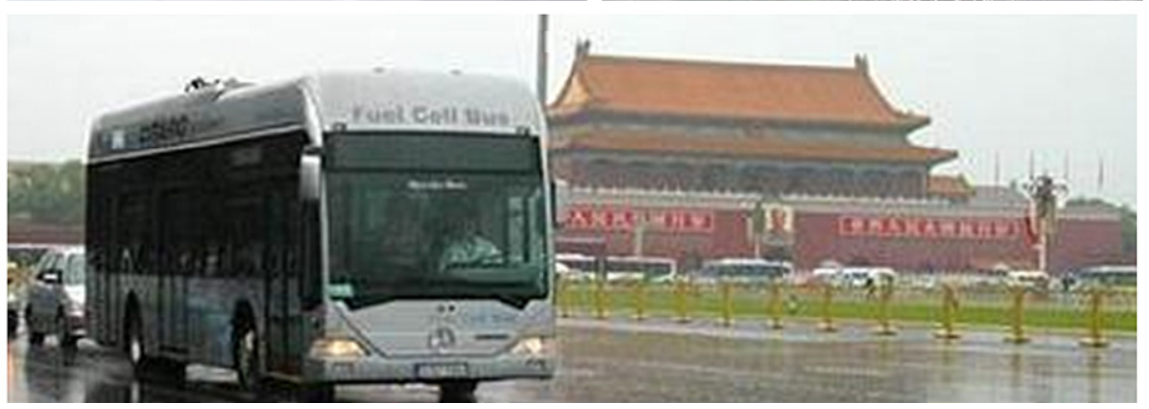

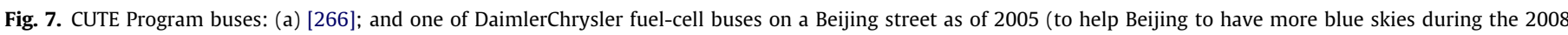
Olympic Games): (b) [267].

Table 2

Technical data for the CUTE program fuel-cell buses [295].

\begin{tabular}{|c|c|c|c|}
\hline Technical data & $\begin{array}{l}\text { Mercedes-Benz Citaro fuel } \\
\text { cell bus }\end{array}$ & $\begin{array}{l}\text { MAN Lion's city H (150 kW } \\
\text { model) }\end{array}$ & MAN Lion's city H (200 kW model) \\
\hline Fuel cell power & Gross power $>250 \mathrm{~kW}$ & $\mathrm{~N} / \mathrm{A}$ & N/A \\
\hline $\begin{array}{l}\text { Net shaft power electric } \\
\text { motor }\end{array}$ & $205 \mathrm{~kW} / 600 \mathrm{~V}$ & N/A & $\mathrm{N} / \mathrm{A}$ \\
\hline Type of ICE & $\mathrm{N} / \mathrm{A}$ & $\begin{array}{l}\text { In-line six cylinder MAN H } \\
2876 \mathrm{UH} 01\end{array}$ & $\begin{array}{l}\text { In-line six cylinder MAN H } 2876 \text { LUH01 with turbo } \\
\text { charging and direct injection }\end{array}$ \\
\hline Hydrogen fuel storage & $\begin{array}{l}9 \text { Pressure cylinders }>40 \mathrm{~kg} \\
\text { at } 350 \mathrm{bar}\end{array}$ & $\begin{array}{l}10 \text { Pressure cylinders } 50 \mathrm{~kg} \\
\mathrm{H}_{2} \text { at } 350 \text { bar }\end{array}$ & 10 Pressure cylinders $50 \mathrm{~kg} \mathrm{H}_{2}$ at 350 bar \\
\hline Range (approx) & $200 \mathrm{~km}$ & $220 \mathrm{~km}$ & $220 \mathrm{~km}$ \\
\hline Speed & Max 80 km/h & Max $80 \mathrm{~km} / \mathrm{h}$ & Max $80 \mathrm{~km} / \mathrm{h}$ \\
\hline $\begin{array}{l}\text { Vehicle dimensions } \\
\qquad(L \times W \times H \mathrm{~m})\end{array}$ & $12.0 \mathrm{~m} \times 2.55 \mathrm{~m} \times 3.67 \mathrm{~m}$ & $12 \mathrm{~m} \times 2.5 \mathrm{~m} \times 3.37 \mathrm{~m}$ & $12 \mathrm{~m} \times 2.5 \mathrm{~m} \times 3.37 \mathrm{~m}$ \\
\hline Passenger capacity & Up to 70 & Up to 83 & Up to 83 \\
\hline
\end{tabular}

developed an electric bicycle powered by a 40 -cell stack, which exhibits a peak power of $378 \mathrm{~W}$, a maximum speed of $16.8 \mathrm{~km} / \mathrm{h}$ and an efficiency of up to $35 \%$. Beckhaus et al. [31] evaluated a $300 \mathrm{~W}$ PEM fuel cell used as an additional power supply for leisure yachts. Siemens [32] has developed a fuel-cell-based air-independent propulsion system intended for use in submarines, such as German U212/214 by Howaldtswerke-Deutsche Werft GmbH (HDW). 
Table 3 lists major companies in this fuel cell transportation sector. In addition, fuel cell applications in the transportation sector require onboard hydrogen storage tanks and their success also rely on the presence of hydrogen fuelling infrastructure. In the latter regard, governments play a decisive role in the development of hydrogen fuelling network. The state of California and the European Union are currently the regions with more fuelling sites [33]. Research on hydrogen storage is also ongoing [34-38].

\subsection{Portable applications}

The fast-growing power demand by portable electronic devices is unlikely satisfied by current battery technology because of its low energy power capability and long charging time. These two issues can be well resolved by using portable/micro PEM fuel cells. Consequently, global production of portable fuel cells has continuously grown, as shown in Fig. 8. Over two-thirds of these units are based on regular PEM fuel cells, a quarter of them consist of DMFC (direct methanol fuel cell) units and the remaining 6\% are not related to PEM technology [39]. The typical power range for portable electronic devices is 5-50 W and several developments focus on a level of $<5 \mathrm{~W}$ for micro power application [20]. A wider range of power, 100-500 W, has also been considered [40].

Many approaches have been proposed for portable/micro fuel cell fabrication. Hayase et al. developed a technique to pattern fuel cell channels and GDL (gas diffusion layer) in Si wafers [41]. Lee et al. employed LIGA (which refers to the German acronym for X-ray lithography-technique: X-ray LIthographie, Galvanoformung (electro-deposition), and Abformtechnik (molding)) to fabricate flow channels in metallic bipolar plates [42]. Ito et al. utilized a technique similar to that used for machining of compact disks to create micro grooves in metal plates [43]. Hahn et al. used reactive ion etching (RIE) to machine microchannels in stainless steel plates [44]. Hsieh et al. proposed a SU-8 photoresist microfabrication process for the fuel cell flow structures [45]. Cha et al. employed various micro/nanofabrication processes, such as lithography, physical vapor deposition (PVD), and focused ion beam (FIB) etch/deposition, to fabricate flow field plates [46]. Madou and

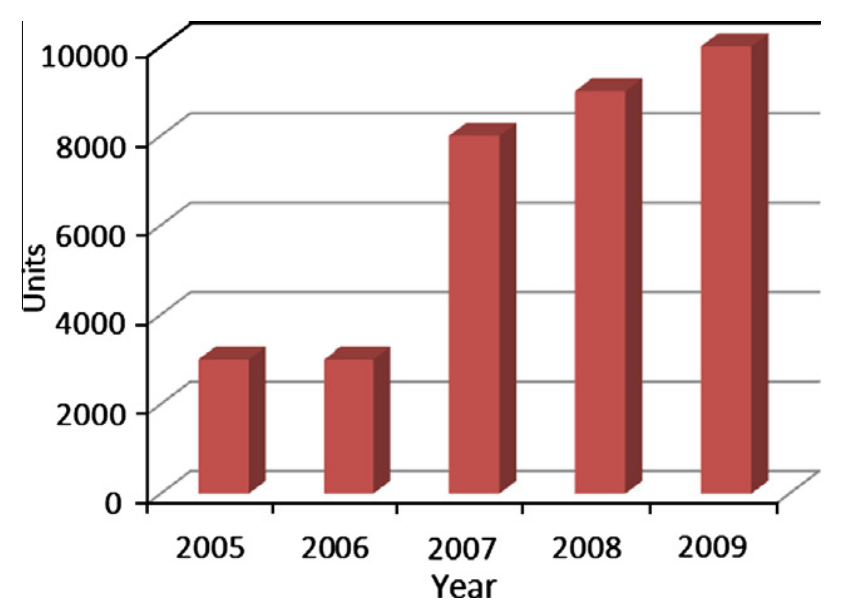

Fig. 8. Portable PEM fuel cell units commercialized [39].

co-workers used carbon obtained by pyrolyzing polymer precursors (called the "C-MEMS process) for the bipolar fluidic plates [47-49]. Fig. 9a shows the bipolar plates with a serpentine flow field after and before carbonization using C-MEMS. The micro channels are in serpentine pattern with a cross-section of $0.8 \mathrm{~mm}$. Fig. 9 also shows the assembled micro PEM fuel cell $(0.8 \times 0.8 \times 0.4 \mathrm{~cm})$, fuel cell bipolar plates and stack. The peak powers reported in the literature are $\sim 82 \mathrm{~mW} / \mathrm{cm}^{2}$ [50], $50 \mathrm{~mW} /$ $\mathrm{cm}^{2}$ [51], $30 \mathrm{~mW} / \mathrm{cm}^{2}$ [45,52], $42 \mathrm{~mW} / \mathrm{cm}^{2}$ [53], $76 \mathrm{~mW} / \mathrm{cm}^{2}$ [49], and $40-110 \mathrm{~mW} / \mathrm{cm}^{2}$ [43]. Henriques et al. [54] discussed the efficiency improvement by altering the cathode channel geometry and achieved an efficiency increase up to $26.4 \%$.

In addition to mobile phones and laptops, portable fuel cells can be used to power toys and utilities such as RC (radio control) cars, boats, robot toys, and emergency lights (e.g. for mining). Fig. 10 displays the hobby-grade vehicles based on Horizon's H-Cell fuel cell system (specifics are listed in Table 4). Fuel cell also receives a great deal of attentions for military application to power portable electrical devices such as radios. Table 5 lists several major companies in the portable PEMFC sector.

Table 3

A list of key companies in the fuel cell transportation sector $[26,28,29]$.

\begin{tabular}{|c|c|c|c|}
\hline Company & Website & Location & Details \\
\hline $\begin{array}{l}\text { BAE } \\
\text { Systems }\end{array}$ & baesystems.com & UK & Integration of a fuel cell APU into its hybrid bus powertrain \\
\hline Ballard & ballard.com & Canada & FC forklifts; HD6, their next generation engine for hybrid fuel-cell buses \\
\hline Daimler & daimler.com & UK & Fuel-cell buses, the new BlueZERO FCV \\
\hline $\begin{array}{l}\text { General } \\
\text { Motors }\end{array}$ & gm.com & USA & $\begin{array}{l}115 \text { units of its fourth generation Equinox FCV, which have been delivered to California, } \\
\text { Germany, China, Korea and Japan }\end{array}$ \\
\hline H2Logic & h2logic.com & Denmark & FC forklifts, focusing on the European market \\
\hline Honda & honda.com & Japan & $\begin{array}{l}200 \text { of its FCX clarity are expected to be shipped to California and to government members } \\
\text { in Japan within the next } 3 \text { years, FC sport, which uses the FCX clarity technology in a sport- } \\
\text { like designed car }\end{array}$ \\
\hline Hydrogenics & hydrogenics.com & Canada & $20 \mathrm{~kW}$ minibuses, APUs and range extenders \\
\hline $\begin{array}{l}\text { Hyundai- } \\
\text { Kia }\end{array}$ & worldwide.hyundai.com & Korea & $\begin{array}{l}\text { Borrego FCEV, using four generation FC technology and is expected to have a 426-mile } \\
\text { range }\end{array}$ \\
\hline Nissan & nissan-global.com & Japan & $\begin{array}{l}\text { X-TRAIN SUV, equipped with Nissan't latest generation FC system, provided Renault with } \\
\text { FC technology for Renault's hybrid drive FC Scenic }\end{array}$ \\
\hline Nuvera & nuvera.com & USA & PowerEdge, hybrid FC forklifts, $82 \mathrm{~kW}$ FC bus \\
\hline $\begin{array}{l}\text { Oorja } \\
\quad \text { Protonics }\end{array}$ & oorjaprotonics.com & USA & DMFC-based charger for forklifts' batteries \\
\hline $\begin{array}{l}\text { Proton } \\
\text { Motor }\end{array}$ & proton-motor.de & Germany & Zemship FC passenger ferry, FC powered street sweeper, light duty truck \\
\hline Protonex & PROTONEX.com & USA & APUs, UAVs (Unmanned Aerial Vehicles) \\
\hline Toyota & toyota.com & Japan & 40 units of its latest FCHV-adv unveiled in Japan \\
\hline Tropical S.A. & tropical.gr & Greece & Hybrid FC bikes and scooters, with the FC charging the battery \\
\hline UTC power & utcpower.com & USA & $120 \mathrm{~kW}$ PureMotion system for FC buses, and $120 \mathrm{~kW}$ FC cars \\
\hline Volkswagen & volkswagen.com & Germany & 16 units of its Passat Lingyu shipped to California for demonstration and testing \\
\hline Volvo & volvo.com & Sweden & APUs \\
\hline
\end{tabular}




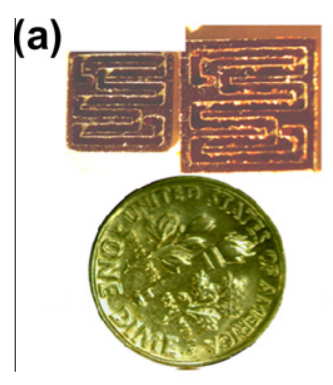

(b)

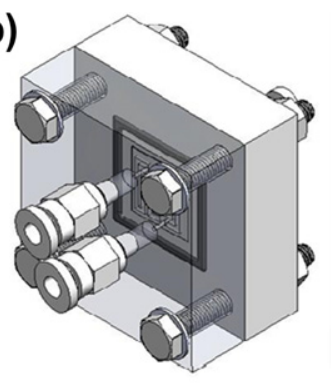

(c)

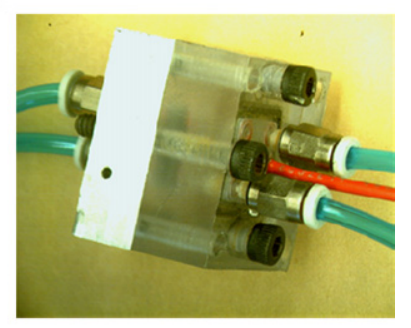

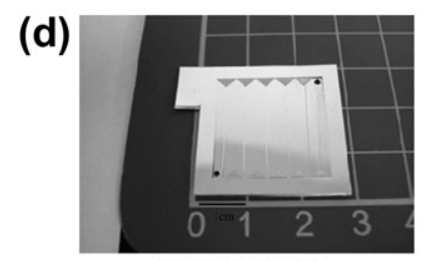

(e)

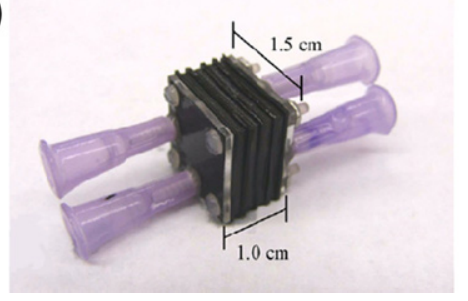

Fig. 9. Micro PEM fuel cell: bipolar plates (a); schematic (b); actual photo (c) [49]; (d) bipolar plates [268] and, (e) stack [48].

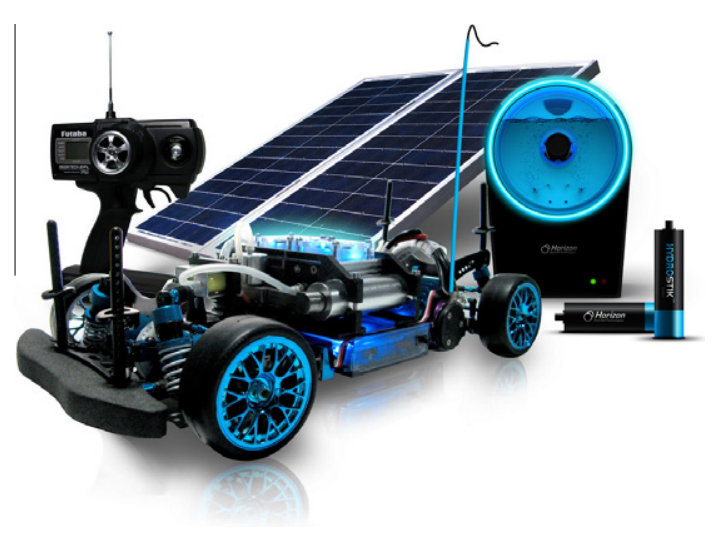

Fig. 10. Image of horizon H-CELL 2.0 [269].

\subsection{Stationary applications}

Current stationary electric power is primarily generated by large central power stations. Large-scale central power stations have many benefits such as high efficiency, but exhibit several inherent disadvantages, e.g. the waste heat that usually cannot

Table 4

Specifications of Horizon H-CELL 2.0 [269].

\begin{tabular}{lll}
\hline & Specifications & \\
\hline \multirow{2}{*}{ Performance } & Peak power & $150 \mathrm{~W}$ (with battery): $18 \mathrm{~A} / 8 \mathrm{~V}$ \\
& Nominal power & $30 \mathrm{~W} / 8 \mathrm{~V}$ \\
& Speed range (TRF & $0-60 \mathrm{~km} / \mathrm{h}$ \\
& $416)$ & \\
& Operating time & $60 \mathrm{~min}$ (two cartridges + fully charged \\
& (normal) & battery) \\
& Operating & $5-35^{\circ} \mathrm{C}$ \\
& temperature & \\
Measurement & Fuel cell weight & $400 \mathrm{~g}$ \\
& $\mathrm{H}_{2}$ cartridge weight & $400 \mathrm{~g}$ \\
& Fuel cell size & $8 \times 6.4 \times 3.45(\mathrm{~cm})$ \\
& $\mathrm{H}_{2}$ cartridge size & $\varnothing 22 \times 81 \mathrm{~mm} \times 2$ units \\
& $\mathrm{H}_{2}$ cartridge weight & $90 \mathrm{~g} \times 2$ units \\
& Hydrogen Energy & $15 \mathrm{Wh}$ per HYDROSTIK ${ }^{\mathrm{TM}}$ cartridge \\
& & $(2 \mathrm{units})$ \\
\hline
\end{tabular}

be efficiently utilized (due to the costly long-distance transport) and power loss during transmission. Distributed power decentralized generation is a way to resolve these disadvantages, which cogenerates heat and power for local usage, a diagram of which can be seen in Fig. 11. Both ICEs and fuel cells can be applied for decentralized small-scale stationary power generation. Except cost, fuel cells exhibit several important advantages over ICEs, such as high electric power conversion efficiency, low noise, zero emission, and easy scale-up.

In this sector, distributed PEM fuel cell systems can be employed to several areas such as heat-power co-generation for household/residential use and uninterruptable power supply (UPS). The former requires further significant improvement in fuel cell cost and lifetime. The DOE's targets for 2011 are $40,000 \mathrm{~h}$ of system durability at a cost of less than $\$ 750 / \mathrm{kW}$, with an electrical-energy-conversion efficiency of $40 \%$ and overall efficiency of $80 \%$ [8]. However, currently few fuel cell units have exhibited a lifetime over $10,000 \mathrm{~h}$. Several units are now available in the market: the GenSys ${ }^{\mathrm{TM}}$ Blue CHP (combined heat and power) system by Plug Power was developed to be compatible with existing home heating systems such as forced air or hot water; the $\mathrm{FCgen}^{\mathrm{TM}}$ 1030V3 stacks developed by Ballard Power Systems can be incorporated into the residential CHP systems in the market. The latter area such as back-up, remote, and uninterrupted power received a growing attention in recent years. The back-up power market is particularly promising for potential customers such as banks, hospitals, and telecom companies which require reliable powers to maintain their business/operation and avoid unexpected power breakdowns. The GenSys ${ }^{\mathrm{TM}}$ fuel cell system has been developed for this application and delivered to more than 50 customer locations in more than 10 countries based on the 2005's data, see Fig. 12 and Table 6 [55]. In 2009 Plug Power received a \$1.4 million award from the New York State Energy Research and Development Authority (NYSERDA) to install and operate three CHP GenSys ${ }^{\mathrm{TM}}$ fuel cell systems in New York State homes [56]. Plug Power also expects to install approximately 1000 systems throughout India by the end of 2010 [57]. FCgen ${ }^{\mathrm{TM}}$ units of Ballard Power Systems have been supplied to IdaTch LLC for use by ACME Group at telecom cellular tower sites in India; and Ballard also works with Dantherm Power A/S of Denmark to provide back-up power solutions to telecommunications providers [58]. In 2008 Ballard has shipped a total of 1855 units for forklifts and back-up power and had expected to double its shipment in 2009 [59]. In Japan, as part of the "Fukuoka 
Table 5

Major companies in the portable PEMFC sector [39].

\begin{tabular}{|c|c|c|c|}
\hline Company name & Website & Location & Details \\
\hline CMR fuel cells & cmrfuelcells.com & UK & 25 W hybrid DMFC laptop battery charger \\
\hline $\begin{array}{l}\text { Viaspace/direct methanol fuel } \\
\text { cell corporation }\end{array}$ & $\begin{array}{l}\text { viaspace.com/ } \\
\text { ae_dmfcc.php }\end{array}$ & USA & Disposable fuel cartridges for DMFCs \\
\hline Jadoo power systems & adoopower.com & USA & $\begin{array}{l}\text { Chemical hydride fuels for fuel cells, } 100 \mathrm{~W} \text { portable electric power supply for } \\
\text { aeromedical evacuation applications }\end{array}$ \\
\hline Horizon & horizonfuelcell.com & China & H-racer series of toys and gadgets, hobbyist fuel cell systems \\
\hline MTI micro & Timicrofuelcells.com & USA & $\begin{array}{l}\text { Collaboration with equipment manufacturers about external chargers, } \\
\text { including universal chargers }\end{array}$ \\
\hline Neah power systems & neahpower.com & USA & DMFC units \\
\hline Samsung DSI & samsungsdi.com & Korea & Military DMFC battery with up to $800 \%$ more durability and $54 \%$ more power \\
\hline SFC Smart Fuel Cell & sfc.com & Germany & APUs for camping and leisure, a portable soldier-worn military fuel cell system \\
\hline Sony & sony.co.jp & Japan & DMFC powered recharging devices for laptops and mobile phones \\
\hline Toshiba & toshiba.co.jp & Japan & $10 \mathrm{~W}$ DMFC battery charger \\
\hline
\end{tabular}

Table 6

GenSys $^{\circledR}$ fuel cell system characteristics [296].

\begin{tabular}{lll}
\hline Product characteristics & & \\
\hline Performance & Min/max continuous output & $1 / 6 \mathrm{~kW}$ \\
& Nominal operating range - voltage & $46-60 \mathrm{VDC}$ \\
& Nominal operating range - current & $18.3-110 \mathrm{~A}$ \\
Fuel & Liquid petroleum gas $(\mathrm{LPG})$ & $\mathrm{GPD} \mathrm{HD}-5 \mathrm{IS} 4576: 1999$ \\
Operation & Ambient temperature & $0-50^{\circ} \mathrm{C}\left(\right.$ option to $\left.-20^{\circ} \mathrm{C}\right)$ \\
& Altitude & $0-2000 \mathrm{~m}(6562 \mathrm{ft})$ \\
Physical & Dimensions $(L \times W \times \mathrm{H})$ & $120 \mathrm{~cm} \times 90 \mathrm{~cm} \times 180 \mathrm{~cm}\left(47^{\prime \prime} \times 35^{\prime \prime} \times 71^{\prime \prime}\right)$ \\
& Weight & $550 \mathrm{~kg}(1212 \mathrm{lbs})$ \\
Emissions & CO/NO $/ \mathrm{SO}_{x} / \mathrm{CO}_{2}$ & $<50 \mathrm{ppm} /<5 \mathrm{ppm} /<1 \mathrm{ppm} /<700 \mathrm{~g} / \mathrm{kW}-\mathrm{hr}$ \\
& Audible noise & $65 \mathrm{dBA} @ 3 \mathrm{~m}(\mathrm{nominal})$ \\
& Remote monitoring & Microprocessor with onboard diagnostics \\
\hline
\end{tabular}

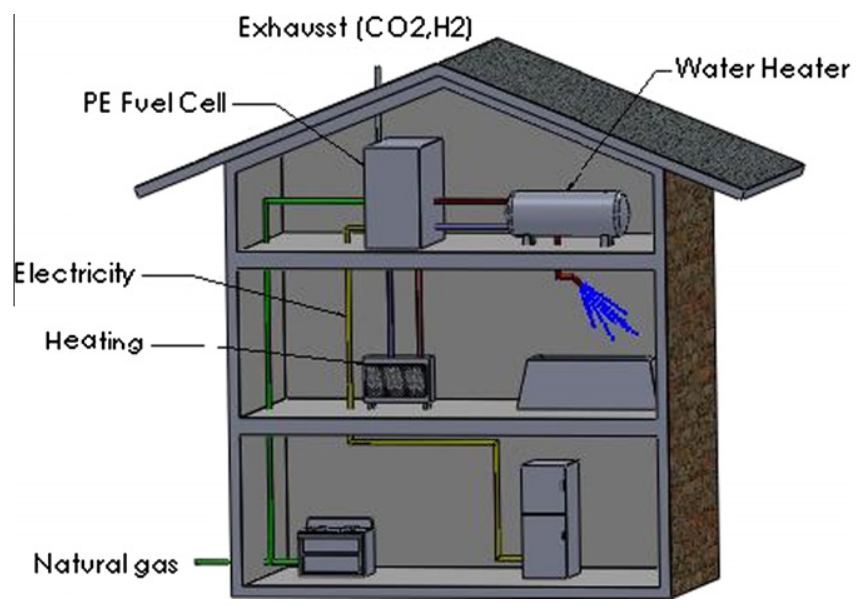

Fig. 11. Schematic of a PEM fuel cell co-generation system [270].

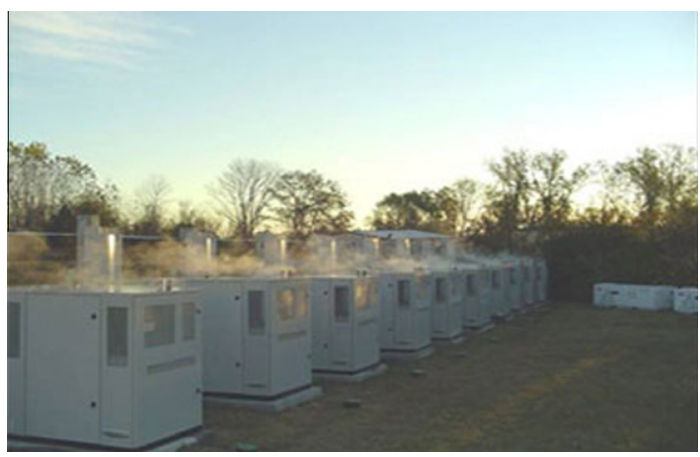

Fig. 12. GenSys ${ }^{\circledR}$ fuel cell system as off-grid distributed generation [271].
Hydrogen Town" model project, Minakazedai and Misakigaoka Danchis in Maebaru City, Fukuoka Prefecture, started installing the $1 \mathrm{KW}$-class ENE FARM residential fuel cell in 2008. In the project, the power systems were installed for about 150 houses in the communities, which was then the world's largest demonstration project of this kind [60,61]. In addition, six Japanese firms, Tokyo Gas, Osaka Gas Co., Nippon Oil Corp., Toho Gas Co., Saibu Gas Co. and Astomos Energy Corp., a joint venture between Idemitsu Kosan Co and Mitsubishi Corp., set their aim to sell a total of about 5000 units of the Ene Farm system in 2009 [62].

In addition to technology development, Wang et al. examined a $5 \mathrm{~kW}$ PEM fuel cell system running on hydrogen and air, which consists of 56 cells [63]. It exhibits a quick start-up at room temperature ( $<1 \mathrm{~min}$ ) and the efficiency of over $30 \%$, see Fig. 13 . Ladewig and Lapicque investigated another $5 \mathrm{~kW}$ stack system with 75 cells and $342 \mathrm{~cm}^{2}$ active area (supplied from Hélion Fuel

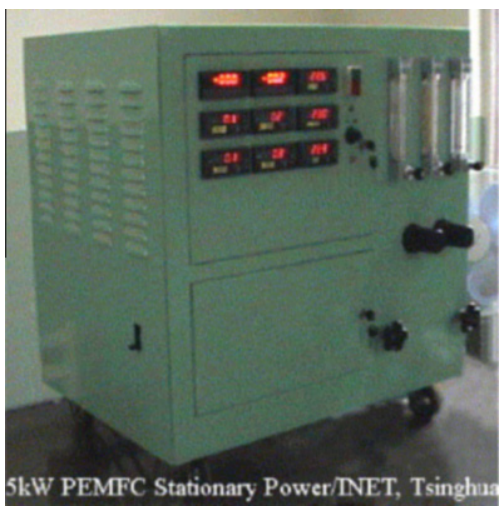

Fig. 13. A $5 \mathrm{~kW}$ PEM fuel cell stationary power [63]. 


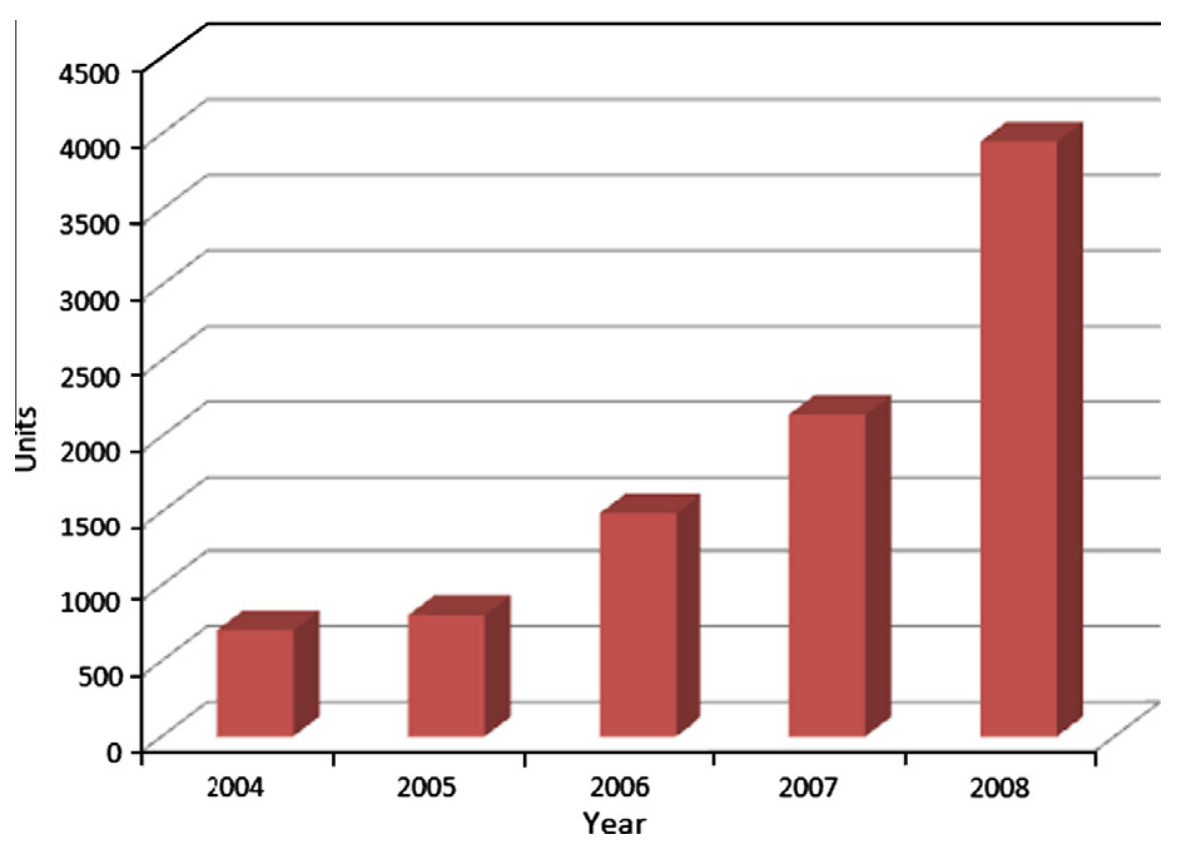

Fig. 14. Small stationary fuel cell plants installed [66].

Table 7

Several major fuel cell companies in the small stationary sector [66].

\begin{tabular}{|c|c|c|c|}
\hline Company & Website & Location & Details \\
\hline Altergy & www.altergy.com & USA & Fuel cell stacks and systems for the UPS market \\
\hline ClearEdge & www.clearedgepower.com & USA & $5 \mathrm{~kW}$ CE5 natural gas fuelled CHP unit \\
\hline Ebara Ballard & & Japan & JV between Ballard and Ebara, 1 kWe PEM system \\
\hline Eneos Celltech & & Japan & JV between Sanyo Electric and Nippon Oil, PEM and SOFC residential units \\
\hline Hydrogenics & www.hydrogenics.com & USA & HyPM-XR, for integration in UPS datacenter cabinets and HyUPS for mobile phone \\
\hline IdaTech & www.idatech.com & USA & Has deal to supply up to $30,0005 \mathrm{~kW}$ UPS systems to the Indian ACME group. \\
\hline Matsushita & & Japan & Delivered 650-1 kWe stacks \\
\hline P21 & www.p-21.de & Germany & Spin out from Vodaphone, now supplies PEM UPS systems \\
\hline Plug Power & www.plugpower.com & USA & GenSys low temperature units is being marketed to telecommunication sector \\
\hline Toshiba FCP & & Japan & $1 \mathrm{~kW}$, wants to be shipping 40,000 units per annum in Japan by 2015 \\
\hline
\end{tabular}

Cell company) [64]. It works with a natural gas reformer and hydrogen purification membrane unit. The DC output from the stack was converted to $240 \mathrm{~V}$ AC as output. The system was installed in Belfort, France with natural gas from the local supply. Hwang and Zou investigated the CHP efficiency and achieved a CHP efficiency of $~ 81 \%$ [65].

Fig. 14 displays the number of small (under $10 \mathrm{~kW}$ ) stationary systems installed between 2004 and 2008. These systems include units installed at home, and uninterrupted and back-up power supply in commercial and remote locations. For 2008 about 95\% of these units are PEM fuel cell, two-thirds are manufactured in North America [66]. It is worthy to note that there is competition from other types of fuel cells, notably MCFCs and SOFCs. These two types exhibit high efficiency, low cost, and fuel flexibility, and are usually considered for larger electric power demand. Their disadvantages are relatively slow start-up and poor dynamic characteristics. Table 7 shows a list of companies working on the stationary applications.

\section{Needs on fundamental research}

Phenomena involved in PEM fuel cell operation are complex; specifically, they involve heat transfer, species and charge transport, multi-phase flows, and electrochemical reactions. Fundamentals of these multi-physics phenomena during fuel cell operation and their relevance to material properties are critically important to overcome the two major barriers, namely durability and cost. These phenomena occur in various components, namely the membrane electrode assembly (MEA) consisting of the catalyst layers (CL) and membrane, gas diffusion layer (GDL) and micro-porous layer (MPL) (together referred to as diffusion media (DM)), gas flow channels (GFCs), and bipolar plates (BP). The cost ratio of the major components is shown in Fig. 2.

Specifically, as schematically shown in Fig. 15, the following multi-physics, highly coupled and nonlinear transport and electrochemical phenomena take place during fuel cell operation: (1) hydrogen gas and air are forced (by pumping) to flow down the anode and cathode GFCs, respectively; (2) $\mathrm{H}_{2}$ and $\mathrm{O}_{2}$ flow through the respective porous GDLs/MPLs and diffuse into the respective CLs; (3) $\mathrm{H}_{2}$ is oxidized at the anode $\mathrm{CL}$, forming protons and electrons; (4) protons migrate and water is transported through the membrane; (5) electrons are conducted via carbon support to the anode current collector, and then to the cathode current collector via an external circuit; (6) $\mathrm{O}_{2}$ is reduced with protons and electrons at the cathode CL to form water; (7) product water is transported out of the cathode CL, through cathode GDL/MPL, and eventually out of the cathode GFC; and (8) heat is generated due to inefficiencies, mainly in the cathode $\mathrm{CL}$ due to the sluggish oxygen reduction reaction (ORR), and is conducted out of the cell via carbon support and BPs. The transport phenomena are three-dimensional because 


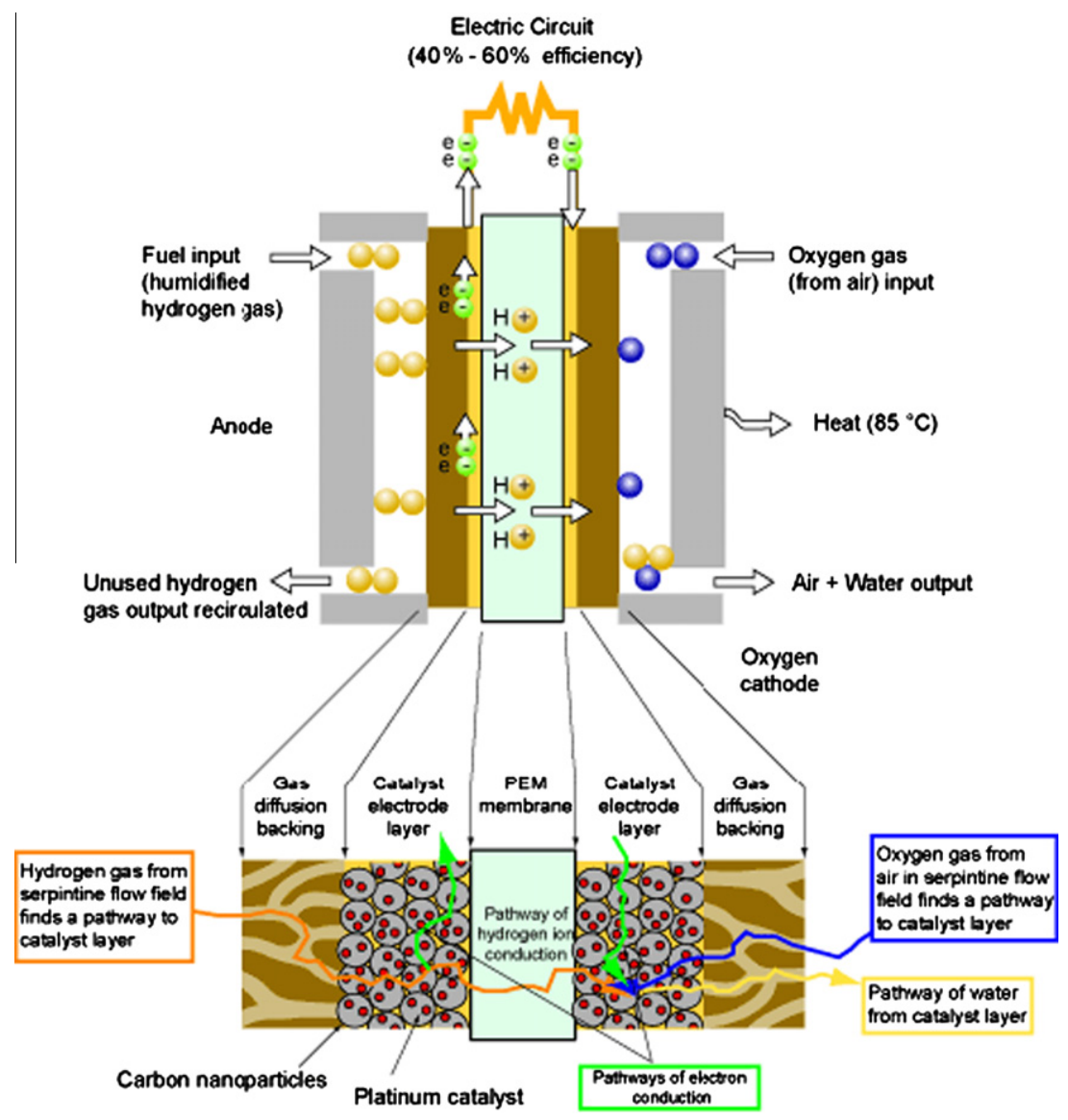

Fig. 15. Phenomena in a PEM fuel cell: two-dimensional sectional view [272].

the flows of fuel $\left(\mathrm{H}_{2}\right)$ and oxidant $\left(\mathrm{O}_{2}\right)$ in the anode and cathode GFCs are usually normal to proton transport through the membrane and gas transport through the respective GDLs/MPLs and CLs. When operating under practical current loads, relatively high inlet humidity, liquid water is present within the fuel cell.
Fundamental models have been developed to examine the transport processes; Tables 8 and 9 list a set of governing equations, based on the laws of conservation of mass, momentum, energy, species and charges and the multi-phase mixture formulation [67-71]. Table 10 lists the typical ranges of the most

Table 8

Fuel cell governing equations [67-71].

\begin{tabular}{lll}
\hline Continuity equation & $\varepsilon \frac{\partial \rho}{\partial t}+\nabla \cdot(\rho \vec{u})=S_{m}$ & $(1)$ \\
Momentum conservation & $\frac{1}{\varepsilon}\left[\frac{\partial \vec{u}}{\partial t}+\frac{1}{\varepsilon} \nabla \cdot(\vec{u} \vec{u})\right]=-\nabla\left(\frac{p}{\rho}\right)+\nabla \cdot \tau+S_{u}$ & $(2)$ \\
Energy conservation & $\frac{\partial \bar{\rho} \bar{c}_{p} T}{\partial t}+\nabla \cdot\left(\gamma_{T} \rho c_{p} \vec{u} T\right)=\nabla \cdot\left(k^{e f f} \nabla T\right)+S_{T}$ & $(3)$ \\
Species conservation $\left(\mathrm{H}_{2} \mathrm{O} / \mathrm{H}_{2} / \mathrm{O}_{2}\right)$ & $\varepsilon^{\text {eff }} \frac{\partial C^{k}}{\partial t}+\nabla \cdot\left(\gamma_{c} \vec{u} C^{k}\right)=\nabla \cdot\left(D^{k, e f f} \nabla C^{k}\right)-\nabla \cdot\left[\left(\frac{m f_{l}^{k}}{M^{k}}-\frac{c_{g}^{k}}{\rho_{g}}\right) \overrightarrow{j_{l}}\right]+S_{k}$ \\
Charge conservation (electrons) & $0=\nabla \cdot\left(\sigma^{\text {eff }} \nabla \Phi_{s}\right)-S_{\phi}$ \\
Charge conservation (protons) & $0=\nabla \cdot\left(\kappa^{\text {eff }} \nabla \Phi_{e}\right)+S_{\phi}$
\end{tabular}

Table 9

Source terms for the conservation equations in each region [67-70,164,185,297].

\begin{tabular}{|c|c|c|c|c|c|}
\hline & $S_{m}$ & $S_{u}$ & $S_{k}$ & $S_{\varphi}$ & $S_{T}$ \\
\hline GFC & 0 & 0 & 0 & - & $S_{f g}$ \\
\hline DM & 0 & $-\frac{\mu}{K_{G D L}} \vec{u}$ & 0 & 0 & $\frac{i^{(s)^{2}}}{\sigma^{\text {eff }}}+S_{f g}$ \\
\hline Catalyst Layer & $M^{w} \nabla \cdot\left(D_{m}^{w} \nabla C^{w}\right)+\sum_{k} S_{k} M^{k}$ & $-\frac{\mu}{K_{C L}} \vec{u}$ & $-\nabla \cdot\left(\frac{n_{d}}{F} i_{e}\right)-\frac{s_{k} j}{n_{k} F}$ & $j$ & $j\left(\eta+T \frac{d U_{o}}{d T}\right)+\frac{i^{(m)^{2}}}{\kappa^{e f f}}+\frac{i^{(s)^{2}}}{\sigma^{e f f}}+S_{f g}$ \\
\hline Membrane & 0 & - & 0 & 0 & $\frac{i^{(m)^{2}}}{\kappa^{e f f}}$ \\
\hline $\begin{array}{l}\text { Electrochemical } \\
\sum_{k} s_{k} M_{k}^{z}=n e^{-} \\
\text {In PEM fuel cel } \\
\text { (Anode) } \mathrm{H}_{2}-2 \\
\text { (Cathode) } 2 \mathrm{H}_{2} \mathrm{C}\end{array}$ & $\begin{array}{l}\text { are: } \\
4 \mathrm{H}^{+}=4 \mathrm{e}^{-}\end{array}$ & where & \multicolumn{3}{|c|}{$\begin{array}{l}M_{k} \equiv \text { chemical formula of species } \\
s_{k} \equiv \text { stoichiometry coefficient } \\
n \equiv \text { number of electrons transferred }\end{array}$} \\
\hline
\end{tabular}

Note: $n_{d}$ is the electro-osmotic drag coefficient for water. For $\mathrm{H}_{2}$ and $\mathrm{O}_{2}, n_{d}=0$. 
Table 10

The electrochemical and transport properties that are frequently used. [67-71].

\begin{tabular}{|c|c|c|}
\hline Description & Unit & Value \\
\hline $\begin{array}{l}\text { Electrochemical kinetics } \\
\text { Exchange current density (Anode, Cathode), } a i_{0} \\
\text { Faraday constant, F } \\
\text { Electrical conductivity of DMs, BPs, } \sigma^{\text {eff }}\end{array}$ & $\begin{array}{l}\mathrm{A} / \mathrm{m}^{3} \\
\mathrm{C} / \mathrm{mol} \\
\mathrm{S} / \mathrm{m}\end{array}$ & $\begin{array}{l}10^{9}, 10^{3}-10^{4} \\
96487 \\
300,20000\end{array}$ \\
\hline $\begin{array}{l}\text { Species transport properties } \\
\mathrm{H}_{2} / \mathrm{H}_{2} \mathrm{O} \text { diffusivity }\left(\mathrm{H}_{2}-\mathrm{H}_{2} \mathrm{O}\right) \text { at standard condition, } D^{k} \\
\mathrm{O}_{2} / \mathrm{H}_{2} \mathrm{O}(\mathrm{v}) \text { diffusivity in the air at standard condition, } D^{k} \\
\text { Viscosity at } 80{ }^{\circ} \mathrm{C}(\mathrm{H} 2 / \text { Air }), D^{k}\end{array}$ & $\begin{array}{l}\mathrm{m}^{2} / \mathrm{s} \\
\mathrm{m}^{2} / \mathrm{s} \\
\mathrm{m}^{2} / \mathrm{s}\end{array}$ & $\begin{array}{l}8.67 / 8.67 \times 10^{-5} \\
1.53 / 1.79 \times 10^{-5} \\
9.88 \times 10^{-6} / 1.36 \times 10^{-5}\end{array}$ \\
\hline $\begin{array}{l}\text { Thermal properties } \\
\mathrm{H}_{2} / \mathrm{N}_{2} / \mathrm{O}_{2} / \mathrm{H}_{2} \mathrm{O}(\mathrm{v}) \text { thermal conductivity, } k^{\text {eff }} \\
\text { Anode/cathode GDL conductivity, } k^{\text {eff }} \\
\text { Anode/cathode CL conductivity, } k^{\text {eff }} \\
\text { Membrane thermal conductivity, } k^{\text {eff }} \\
\text { Anode/cathode bipolar plate thermal conductivity, } k^{\text {eff }} \\
\mathrm{H}_{2} / \mathrm{N}_{2} / \mathrm{O}_{2} / \mathrm{H}_{2} \mathrm{O}(\mathrm{v}) \text { specific heat at } 80^{\circ} \mathrm{C}, c_{p} \\
\text { Anode/cathode GDL heat capacity, } \rho c_{p} \\
\text { Anode/cathode CL heat capacity, } \rho c_{p} \\
\text { Membrane heat capacity, } \rho c_{p} \\
\text { Anode/cathode bipolar plate heat capacity, } \rho c_{p} \\
\text { Latent heat of liquid water-vapor/liquid-solid water phase change }\end{array}$ & $\begin{array}{l}\mathrm{W} / \mathrm{m} \mathrm{K} \\
\mathrm{W} / \mathrm{m} \mathrm{K} \\
\mathrm{W} / \mathrm{m} \mathrm{K} \\
\mathrm{W} / \mathrm{m} \mathrm{K} \\
\mathrm{W} / \mathrm{m} \mathrm{K} \\
\mathrm{J} / \mathrm{kg} \mathrm{K}^{3} \\
\mathrm{~J} / \mathrm{K} \mathrm{m}^{3} \\
\mathrm{~J} / \mathrm{K} \mathrm{m}^{3} \\
\mathrm{~J} / \mathrm{K} \mathrm{m}^{3} \\
\mathrm{~J} / \mathrm{K} \mathrm{m}^{3} \\
\mathrm{~J} / \mathrm{kg}^{2}\end{array}$ & $\begin{array}{l}0.170 / 0.024 / 0.024 / 0.024 \\
0.3-3 \\
0.3-1.5 \\
0.95 \\
>10.0 \\
14400 / 1041 / 917 / 2000 \\
5.68 \times 10^{5} \\
1.69 \times 10^{6} \\
1.65 \times 10^{6} \\
1.57 \times 10^{6} \\
2.26 \times 10^{6} / 3.34 \times 10^{5}\end{array}$ \\
\hline $\begin{array}{l}\text { Material properties } \\
\text { Permeability of anode/cathode GDL, } \mathrm{K}_{\mathrm{GDL}} \\
\text { Permeability of anode/cathode CL, } \mathrm{K}_{\mathrm{CL}} \\
\text { Anode/cathode GDL porosity, } \varepsilon \\
\text { Anode/cathode CL porosity, } \varepsilon \\
\text { Ionomer volume fraction in } \mathrm{CL}, \varepsilon_{m} \\
\text { Equivalent weight of ionomers, EW } \\
\text { Dry density of membrane, } \rho\end{array}$ & $\begin{array}{l}\mathrm{kg} / \mathrm{mol} \\
\mathrm{kg} / \mathrm{m}^{3}\end{array}$ & $\begin{array}{l}1.0 \times 10^{-12} \\
1.0 \times 10^{-13} \\
0.4-0.8 \\
0.3-0.5 \\
0.13-0.4 \\
0.9,1.1 \text { or } 1.2^{*} \\
1.98 \times 10^{3^{*}}\end{array}$ \\
\hline
\end{tabular}

${ }^{*}$ Several typical Nafion ${ }^{\circledR}$ membranes.
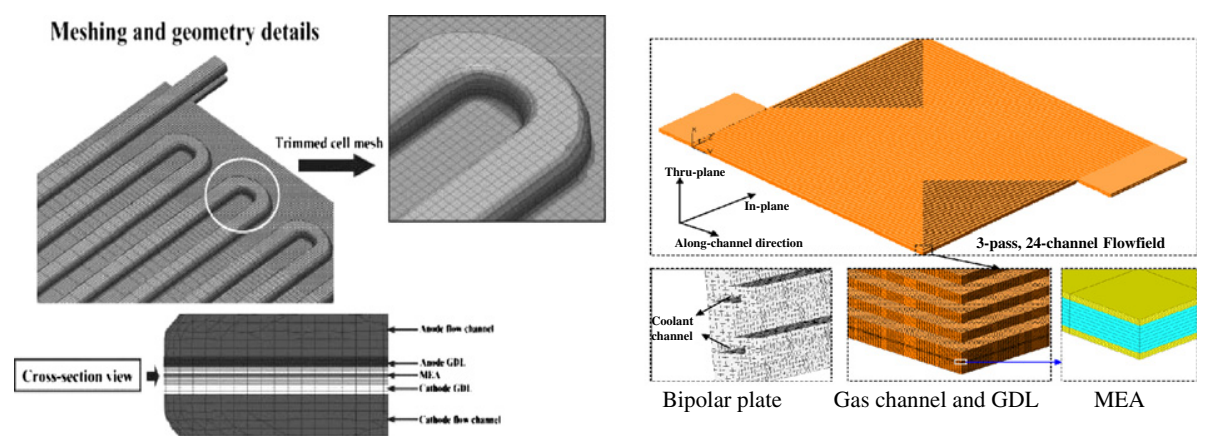

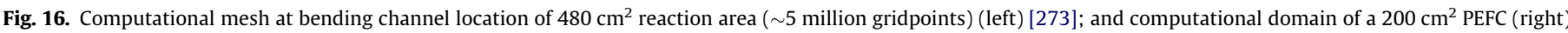
( $\sim 23$ million gridpoints) [240].

model parameters. Figs. 16 and 17 show examples of computational meshes used in large-scale simulation of a single PEM fuel cell with the major components and predicted current density distribution in the membrane, respectively. A large variation of reaction current density is indicated in the figure, and this detail information will aid the design and fundamental study of PEM fuel cell, in particular helping PEMFC developers overcome the two major barriers. The remaining of this session details what fundamentals are considered understood, what are partially understood, what are not yet understood but need further study.

\subsection{Membrane}

Membrane refers to a thin layer of electrolyte (usually $\sim 10$ $100 \mu \mathrm{m}$, e.g. $18 \mu \mathrm{m}$ for Gore 18 and $175 \mu \mathrm{m}$ for Nafion ${ }^{\circledR} 117$ ), which conducts protons from the anode to the cathode. Desirable membrane materials are those that exhibit high ionic conductivity, while preventing electron transport and the cross-over of hydrogen fuel from the anode and oxygen reactant from the cathode.
In addition, they must be chemically stable in an environment with HO- and HOO radicals, thermally stable throughout the operating temperatures, and mechanically robust. Current membranes are mostly based on the perfluorosulfonic acid, the most prominent of which, Nafion, was first developed by the DuPont Company in 1960s. Nafion ${ }^{\circledR}$ has a backbone structure of polytetrafluoroethylene (PTFE, known by the trade name Teflon), which provides membrane with physical strength. The sulfonic acid functional groups in Nafion ${ }^{\circledR}$ provide charge sites for proton transport. Additionally, other perfluorinated polymer materials such as Neosepta-FTM (Tokuyama), Gore-Select ${ }^{\mathrm{TM}}$ (W.L. Gore and Associates, Inc.), Flemion $^{\mathrm{TM}}$ (Asahi Glass Compnay), Asiplex ${ }^{\mathrm{TM}}$ (Asahi Chemical Industry) are also adopted for PEM fuel cell applications. In addition, membrane materials that can operate at high temperatures (100$200^{\circ} \mathrm{C}$ ) are preferred for high temperature PEM fuel cell which has advantages of better catalyst tolerance to $\mathrm{CO}$ and cooling strategy for fuel cell $[72,73]$.

The Nafion-based membranes are costly primarily due to their complex fabrication process [74]. Research on cost-effective 


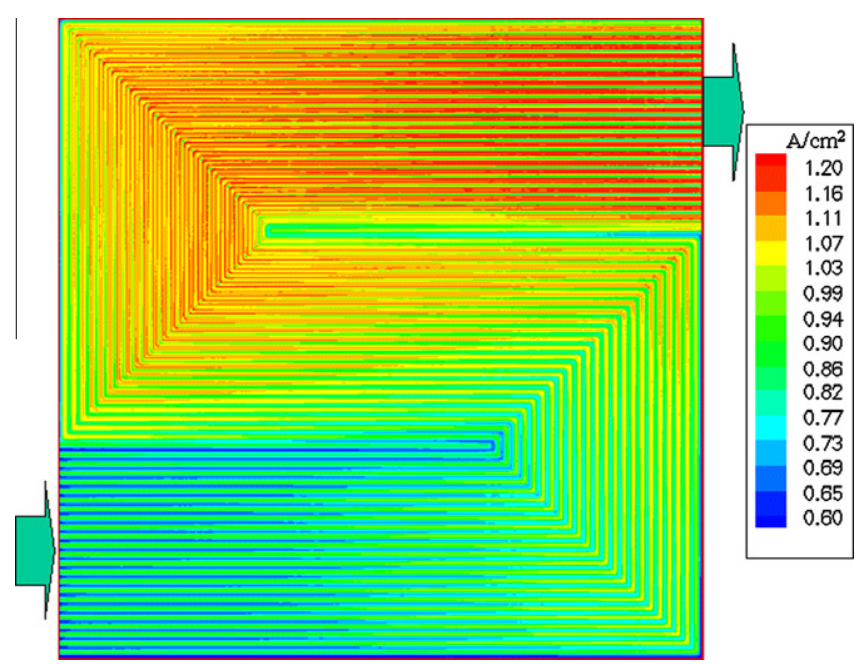

Fig. 17. Current density distribution in the membrane [240].

high-performance electrolyte materials has been active in the entire course of fuel cell development. Solvay Solexis is developing Hyflon ${ }^{\circledR}$ ion ionomers, also known as short side chain (SSC) ionomer (which was originally developed by Dow Chemicals Company and then abandoned [75]) that can exhibit a better performance and durability than Nafion ${ }^{\circledR}$ in several cases. However, severe degradation has been observed for this membrane material [76]. Phosphoric acid-doped polybenzimidazole (PBI) membrane is a promising material for high temperature membrane due to its high proton conductivity at temperatures up to $200^{\circ} \mathrm{C}$ and low methanol/ethanol permeability. However, there are concerns on low proton conductivity at low temperature (important for cold start) and low solubility of oxygen along with evaluation of stack components including bipolar plates, seals and coolant, and thermal and water management [77]. Hydrocarbon-based membranes have been attempted by PolyFuel for fuel cell [78].

Two major transports take place in membranes, i.e. proton and water transport. Gierke and Hsu described the polymeric membrane, known as a cluster model, in terms of an inverted micellar structure in which the ion-exchange sites are separated from the fluorocarbon backbone, forming spherical clusters (pores), connected by short narrow channels [79]. The cluster sizes depend on local water content. The main driving force for proton transport is the gradient of electrical potential of the electrolyte. That is, protons transport across the membrane mainly due to the existence of electrolyte potential gradient; the effect of diffusion is relatively small. Water in the membrane is essential for proton transport: one mechanism is called the "vehicular" diffusion. By forming hydronium ions $\left(\mathrm{H}_{3} \mathrm{O}^{+}\right)$, protons, can transport from high to low proton concentration regions, which is called the vehicular diffusion [80]. Therefore, this mechanism largely depends on the diffusivity of water in membranes. Another is through the "Hopping" mechanism that takes place when sufficient water content is presented so that the side chains of sulfonic groups are connected, where protons can move directly from one site to another $[81,82]$. One of the most prevalently used proton-conductivity models is the empirical correlation developed by Springer et al. [83] for the Nafion ${ }^{\circledR} 117$ membrane:

$$
\kappa=(0.005193 \lambda-0.00326) \exp \left[1268\left(\frac{1}{303}-\frac{1}{273+T_{\text {cell }}}\right)\right]
$$

At subfreezing temperature, the Nafion ${ }^{\circledR}$ membrane remains conductive to protons due to the existence of non-frozen water in the membrane, see Fig. 18 [84-87]. The water content $\lambda$, usually defined

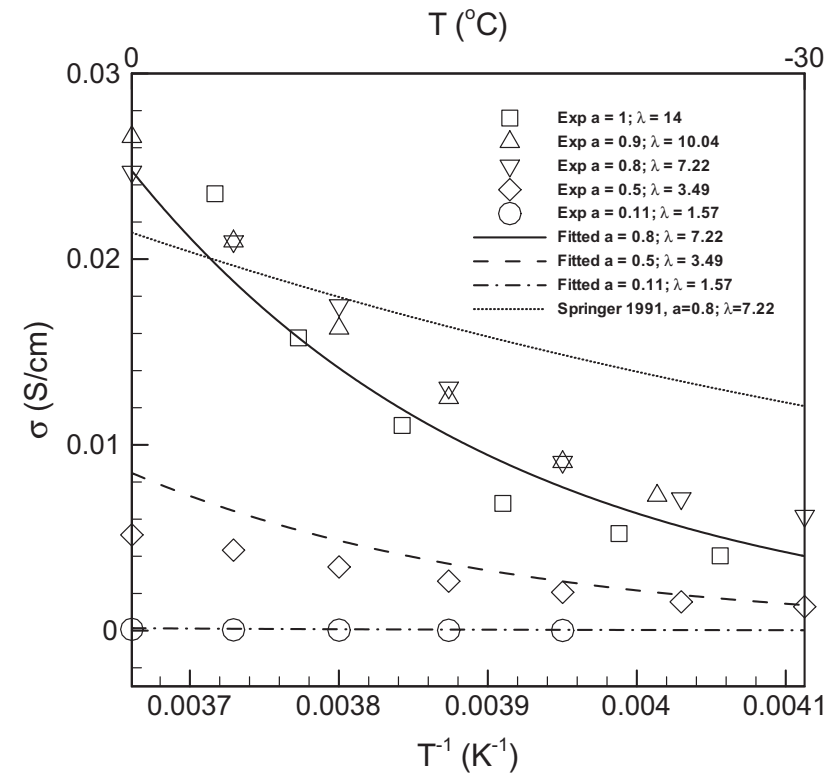

Fig. 18. Ionic conductivity of the membrane at subfreezing conditions $[83,85]$.

as the number of moles of water per mole of acid sites attached to the membrane (namely, $\mathrm{SO}_{3} \mathrm{H}$ ), is related to the water activity of the surrounding fluids, see Fig. 20 [88,89]. Based on their experimental observation, Zawodzinski et al. [88] indicated that there exists a discontinuity in the membrane water content between the membrane with liquid water and with saturated water vapor at equilibrium. Both of the surrounding waters exhibit unity water activity. This phenomenon, generally referred to as "Schröeder's paradox", is observed in a wide variety of polymer materials and solvents [90-92]. Though current correlations are mostly simple and easy to implement in a full fuel-cell computer model but only valid for the conditions under which the fitted data was collected. For each new membrane, a whole new set of data must be generated at the conditions of interest. Therefore, a better model of proton conductivity is highly needed [93]. Another important membrane property is the water diffusivity which also depends on the local membrane water content, see Fig. 19 [83,94]. In addition to diffusion, the electro-osmotic drag (EOD) can transport water from the anode to cathode and the EOD coefficient might be a function of water content (both linear and stepwise correlations have been proposed.) [95-100].

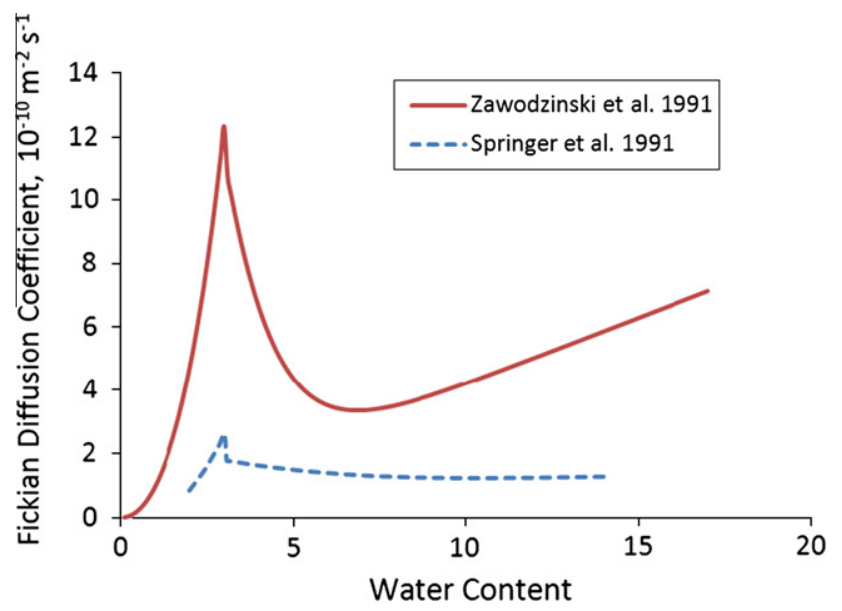

Fig. 19. Fickian diffusion coefficients of water in Nafion ${ }^{\circledR}$ membrane at different water contents and at $80^{\circ} \mathrm{C}$ by using different correlations $[94,274]$. 


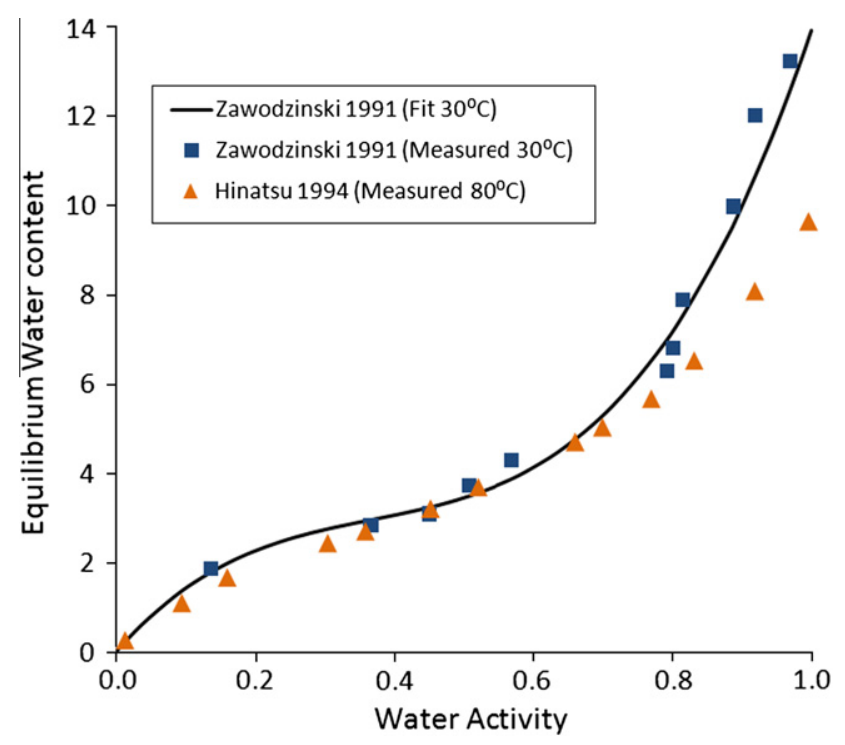

Fig. 20. Equilibrium water uptake relation for Nafion ${ }^{\circledR}$ membranes at $30^{\circ} \mathrm{C}$ $[83,275,276]$.

When liquid water is present at the membrane surfaces, hydraulic permeation can take place [101], which is driven by the pressure difference at the membrane surfaces. A correlation, proportional to the membrane water content, was proposed by Bernardi and Vergrugge [102] and Büchi and Srinivasan [103].

Ionic and water transport in membranes plays an important role in fuel cell operation. The ionic transport resistance directly determines the Ohmic loss of cell voltage and associated Joules heating. Formation of local hot spots may occur at high resistance sites, leading to membrane pin-hole formation and other degradation issues. A sufficient hydration level of membranes is critical to their ionic conductivity. It has also been observed that dryness of membranes may cause cracks and degradation issues. In addition, using experimental data obtained by Zawodzinski et al. [96,104], Springer et al. [83] developed an empirical correlation relating proton conductivity to water content in the membrane, see Eq. (7). They also correlated the electro-osmotic drag coefficient with water content. These two empirical correlations put forth by Springer et al. enjoy widespread usage in the PEMFC literature. Recently, Chen and Hickner $[105,106]$ formulated a new constitutive model for predicting proton conductivity in polymer electrolyte. Their conductivity model depends on the molar volumes of dry membrane and water but otherwise requires no adjustable parameter. Predictions computed from Chen and Hickner's conductivity model yield good agreement with experimental data from the literature and those from their own measurements for a wide range of water contents. Weber and Newman [107,108] developed a comprehensive membrane model that treats membrane swelling and seamlessly and rigorously accounts for both vapor and liquid-equilibrated transport modes using a single driving force of chemical potential. The transition between the two modes is determined based on the energy needed to swell and connect the waterfilled nano-domains. However, there are still some discrepancies to be overcome such as an underestimation of the interfacial water mass-transport resistance and a lack of consideration of membrane state or history.

\subsection{Catalyst layers}

The catalyst layer $(\mathrm{CL})$ is where the hydrogen oxidation reaction (HOR) or oxygen reduction reaction (ORR) takes place. CL is usually very thin (about $10 \mu \mathrm{m}$ ). Several phases contained in a CL are key to the electrochemical reaction: (1) carbon support with Pt catalyst particles dispersed on the carbon surface, (2) ionomer, and (3) void space. The catalyst plays the critical role of reducing the reaction activation barrier. Hydrogen fuel is oxidized in the anode whereas the ORR takes place in the cathode (see Table 9). Platinum or platinum alloy is popular catalyst for both the ORR and HOR, therefore the CL contributes a significant portion of cost for a fuel cell. Pt and several of its alloys (Pt-Co, Pt-Ni, Pt-Fe, Pt-V, Pt-Mn and Pt-Cr) exhibit good catalyst kinetics [109-118]. The Pt loading is an important factor in the CL development. The DOE target is 0.3 and $0.2 \mathrm{mg} / \mathrm{cm}^{2}$ for 2010 and 2015, respectively, and most recently the $3 \mathrm{M}$ Company achieves $0.15 \mathrm{mg} / \mathrm{cm}^{2}$ with PtCoMn alloy [119]. In addition to Pt-loading reduction, one active research area is to explore new catalyst materials. Two major approaches have gained momentum. The first of which is to replace the Pt with another less expensive precious metal, such as ruthenium or palladium $[120,121]$. The second is to use non-precious metal catalysts (NPMC). Bashyam and Zelenay examined the cobalt-polypyrrolecarbon (Co-PPY-C) composite. This catalyst exhibits good activity with a Co loading of $6.0 \times 10^{-2} \mathrm{mg} \mathrm{cm}^{-2}$ and stability in PEM fuel cells, and generates $0.2 \mathrm{~A} / \mathrm{cm}^{2}$ at $0.50 \mathrm{~V}$ and a peak power density of $0.14 \mathrm{~W} / \mathrm{cm}^{2}$ [122]. Some studies are focused on heat-treated $\mathrm{Fe}$ and $\mathrm{Co}-\mathrm{N} / \mathrm{C}$ catalysts, of which a review is given by Bezerra et al. [123]. A review on materials such as $\mathrm{Cu}, \mathrm{Pd} / \mathrm{Co}, \mathrm{Mo}_{4.2} \mathrm{Ru}_{1.8} \mathrm{Se}_{8}$, $\mathrm{WC}+\mathrm{Ta}$ and $\mathrm{LaMnO}_{3+0}$ was provided by Wang [124]. Table 11 shows that early NPMCs exhibit much lower performance than Pt as an electrocatalyst. Most recently, a comprehensive work on NPMCs was presented by Zelenay [125]. They achieved an OCV of $1.04 \mathrm{~V}$ and volumetric ORR activity of $165 \mathrm{~A} / \mathrm{cm}^{3}$ (volume based on electrode and over 100 times improvement) with CyanamideFe-C catalyst, which meets the DOE 2010 target. They also showed a rapid improvement (around 30 times improvement from 2008 to 2010) in several other NPMCs such as PANI-Fe/EDA-Co-C. In addition, $\mathrm{CO}$ adsorption at the Pt site causes severe loss in performance. To improve the CO tolerance by PEM fuel cells, the use of binary Pt-Ru catalysts and oxygen bleeding technique were proposed in 1980s and 1990s [126,127] and various materials for CO tolerant catalysts (Zeolite support, Pt-Mo, Sulfided catalysts, etc) are under research [128].

Improving the Pt utilization is another way for reducing the Pt loading and $\mathrm{CL}$ cost. The reactions take place at the triple-phase boundaries; the area of this active catalyst surface is usually large

Table 11

Metal ORR catalysts [124].

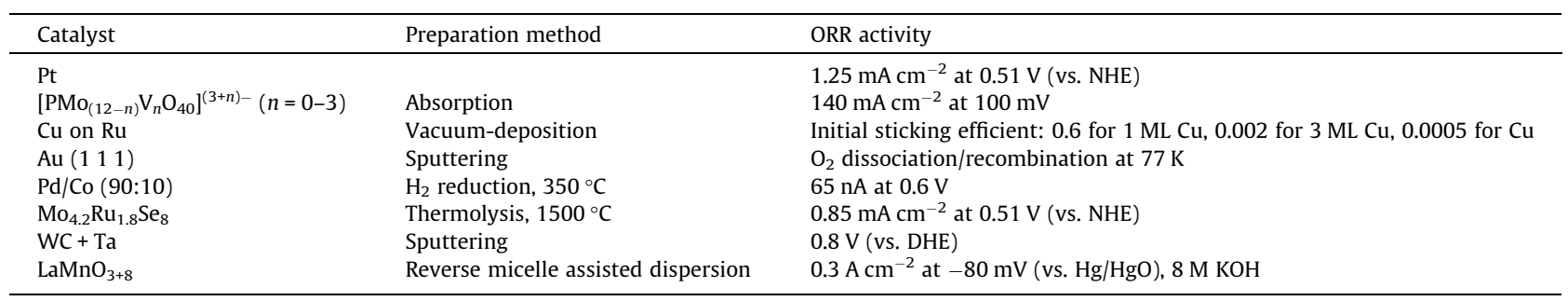


to improve the Pt utilization. This can be directly seen from the well-known Butler-Volmer equation:

$$
\begin{aligned}
\sigma \cos \left(\theta_{c, G D L}\right)\left(\frac{\varepsilon_{G D L}}{K_{G D L}}\right)^{1 / 2} J(s) & =P_{c, G D L}=P_{c, M P L} \\
& =\sigma \cos \left(\theta_{c, M P L}\right)\left(\frac{\varepsilon_{M P L}}{K_{M P L}}\right)^{1 / 2} J(s)
\end{aligned}
$$

where $j$ is the reaction current or transfer current per unit volume, $i_{0}$ the exchange current density, a the specific active area per unit volume, $F$ the faraday constant, $R$ the universal gas constant, and $\eta$ the surface overpotential. The value of $a$ is usually $100-1000$, significantly increasing the catalytic activity, which is related to the structural information of CLs. Though thin, the CL structure is complex, generally consisting of several interconnected networks for proton, electron, and reactant transport, respectively. Mukherjee and Wang [129] and Kim and Pitsch [278] proposed numerical techniques to digitally reconstruct this microstructure (see Fig. 21) [129]. Inside CLs, transport takes place in various phases. Despite the small thickness, the reaction rate may vary significantly across the layer arising from transport resistance. A dimensionless parameter $\hbar$ was identified recently by Wang and Feng to quantify degree of the reaction spatial variation, see Fig. 22 [130]. Wang et al. developed a detailed DNS (direct numerical simulation) study on the transport of oxygen and proton within the catalyst layer based on their reconstructed CL [131-133] and predicted a spatially varied profile of reaction rate. Wang et al. [131,132] indicated that the tortuosity of the ionomer in CLs might be over 3.0 and the high reaction current takes place in $15-20 \%$ of the CL. This spatial variation likely reduces local catalyst utilization; multi-layer configurations can be developed to modify the reaction distribution and optimize the electrode composite [129,134-136].
Another important issue related to CLs is their durability. The catalyst layer is susceptible to material degradation during operation. A primary degradation mechanism is Pt agglomeration or loss of activation sites. Ferreira et al. showed that platinum particles dissolved in the ionomer and reformed on larger particles, called Ostwald ripening [137]. Borup et al. showed through their XRD analysis that platinum particles may not be sufficiently anchored to the carbon support, and move into the ionomer portion, and during cycling will coalesce onto bigger particles, see Fig. 23 [138]. Some studies indicated that Pt moves from the electrode into the electrolyte membrane, reducing the active catalyst area [139-143]. Fig. 24 shows SEM micrographs of the aged MEAs, indicating a band of platinum inside the membrane on the cathode side during potential cycling. As the number of cycles is increased, the cathode becomes noticeably thinner from about $17 \mu \mathrm{m}$ at $0 \mathrm{cy}-$ cles to $14 \mu \mathrm{m}$ at 10,000 cycles. Regarding NPMCs, Zelenay [125] recently showed a high durability with PANI-based catalysts upon potential holding at OCV and potential (RDE) and voltage (fuel cell) cycling, up to 30,000 cycles. They also indicated that durability of catalysts may not be simply a function of support corrosion resistance or $\mathrm{H}_{2} \mathrm{O}_{2}$ generation, although these two factors still have impacts. In addition, impurities in the reactants, such as $\mathrm{NH}_{3}, \mathrm{H}_{2} \mathrm{~S}, \mathrm{CO}$, $\mathrm{NO}_{x}$ and $\mathrm{SO}_{2}$, can block catalyst sites, reducing the active catalyst area. Garzon et al. showed that $\mathrm{H}_{2} \mathrm{~S}$ concentrations of $10 \mathrm{ppb}$ produced negative effects on cell performance [144]. The effect of ammonia was studied by Uribe et al., who outlined possible mechanisms, and later by Zhang et al. [145]. To avoid the ammonia impact, Uribe et al. suggested passing the $\mathrm{H}_{2}$ fuel stream through the $\mathrm{H}^{+}$forming ion exchange resin before entering the anode [146]. Gottesfeld and Pafford recommended bleeding $\mathrm{O}_{2}$ or air into the fuel stream to get rid of $\mathrm{CO}$ and its poisoning [127]. Both experiment and modeling have been conducted on this study (a)

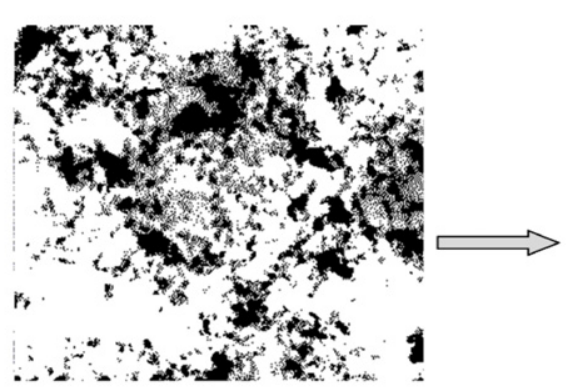

2D TEM CL Image

(pore $\rightarrow$ white, solid $\rightarrow$ black/grey)

(c)

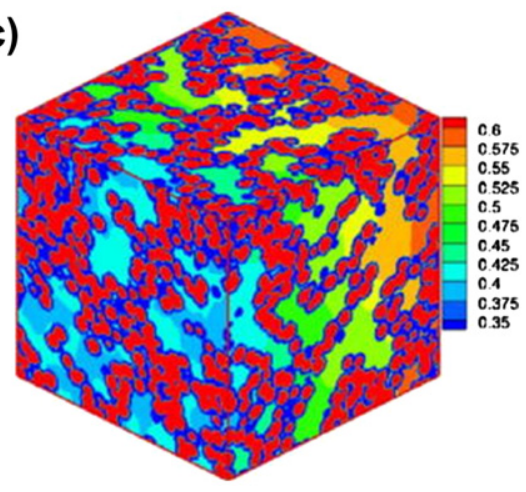

(b)

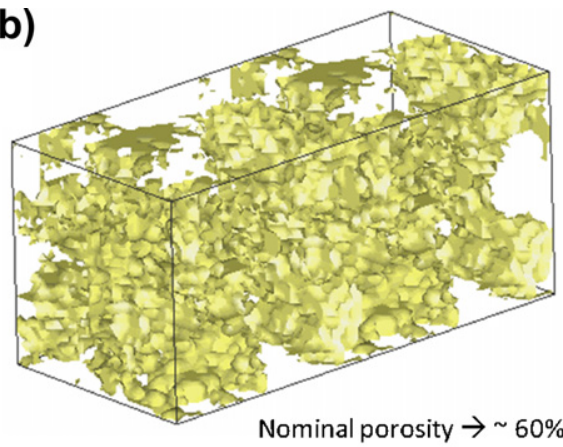

3D Reconstructed CL Microstructure

Mixed electrolyte/electronic phase $\rightarrow$ solid phase (solid $\rightarrow$ yellow (in color), pore $\rightarrow$ white)

(d)

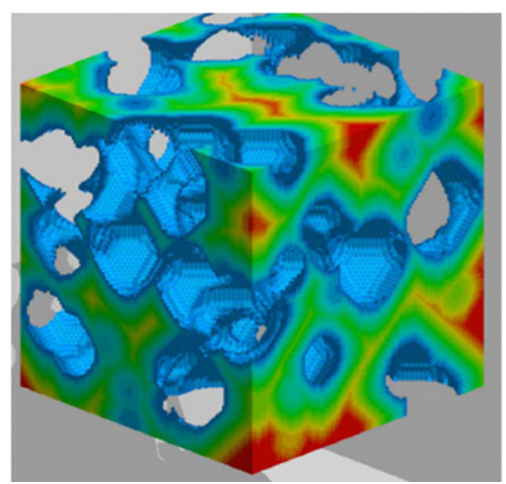

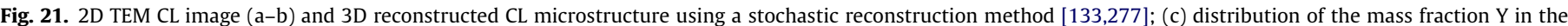

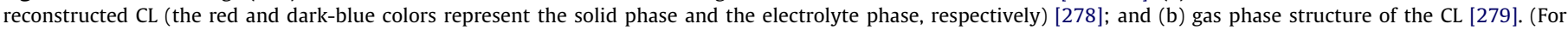
interpretation of the references to colour in this figure legend, the reader is referred to the web version of this article.) 


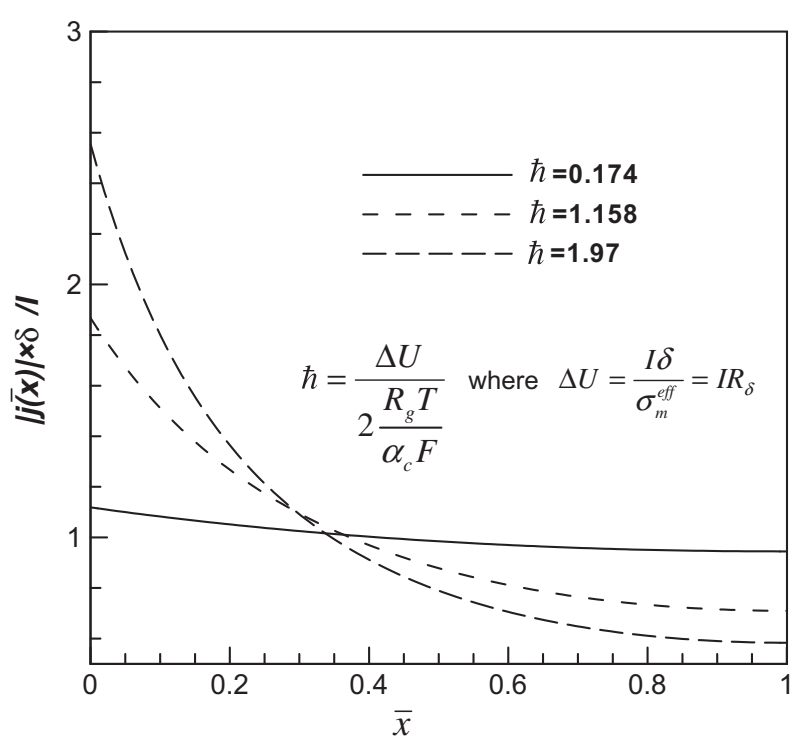

Fig. 22. The spatial variation of the reaction rate across the catalyst layer [130], where the y axis denotes the dimensionless reaction rate, $h$ the nonuniformity, $\delta$ the thickness of the catalyst layer, $I$ the current density, and $\sigma_{m}^{\text {eff }}$ the effective ionic conductivity.

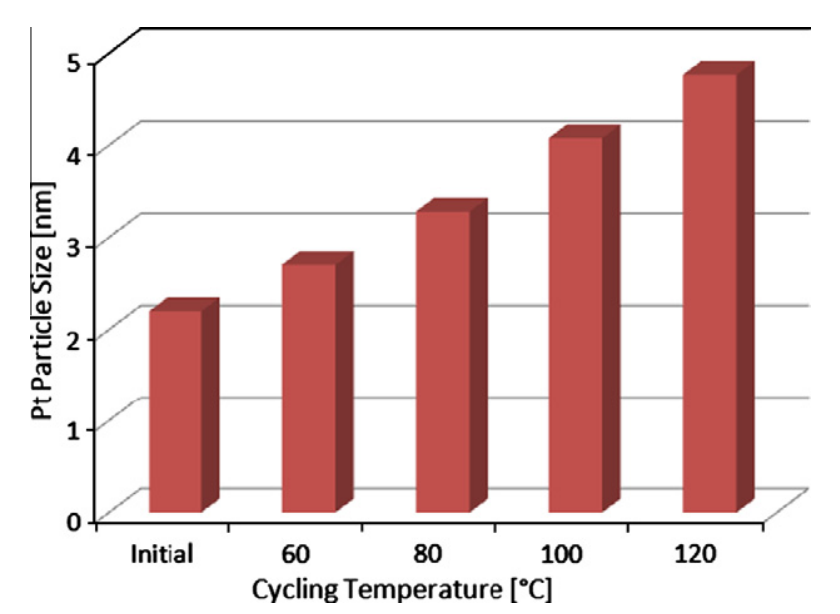

Fig. 23. Platinum particle size after cycling from 0.1 to $0.96 \mathrm{~V}$ as a function of operating cell temperature [138].

[147-149]. Franco et al. examined the long-term effect of CO poisoning under current cycled operations and Wan et al. suggested dual catalyst layers, in which the outer layer acts as a CO filter [150,151].

In addition, avoiding CL flooding is of critical importance for optimal PEMFC performance and durability; however it is not well understood. The ability to model transport and electrochemical reactions in CLs is crucial, particularly for the cathode in which the ORR is sluggish and inefficient and water is generated. The water content of the cathode CL directly affects the protonic conductivity in this domain and thus the reaction-rate distribution. There is a great need to elucidate mechanisms of liquid-water transport/evaporation in the CL and the interactions with the CL microstructure and wettability and to develop a predictive tool to enable microstructural and surface prototyping of future generations of CL. Some CL component models have been developed by Siegel [152] and Siegel at al. [153], Harvey [154], Harvey et al. [155], Marr and Li [156], Schwarz and Djilali [157], and Shah et al. [158], but they need to be improved and integrated into the full PEMFC model. Specially, Harvey et al. [155] compared three different approaches for describing the cathode catalyst layer: namely, a thin-film model, discrete-catalyst volume model, and agglomerate model. They indicated that for a given electrode overpotential, the thin-film model significantly over-predicts the current density and exaggerates the variation in current density both along and across the channel, and the agglomerate model predicts noticeable mass transport losses. In addition, the CL is usually thin, but may be subjected to mass transport limitation [131,132] or a considerable ohmic loss [130]. In this regard, further reducing the $\mathrm{CL}$ thickness is necessary to improve its performance. A CL model that properly captures the key transport phenomena and the HOR or ORR reaction at the three-phase interface can be employed to optimize the CL thickness. Specifically, such a model can elucidate the effect of catalyst-layer thinning on PEMFC performance. Furthermore, thinner CLs (in the scale of $1 \mu \mathrm{m}$ ) can reduce the catalyst loading and hence the $\mathrm{CL}$ cost. Research efforts are definitely needed in this area.

\subsection{Gas diffusion layers and micro-porous layers}

Gas diffusion layers (GDLs) and micro-porous layer (MPLs), together called DM (diffusion media), play multiple roles: (1) electronic connection between the bipolar plate with channel-land structure and the electrode, (2) passage for reactant transport and heat/water removal, (3) mechanical support to the membrane electrode assembly (MEA), and (4) protection of the catalyst layer from corrosion or erosion caused by flows or other factors $[159,160]$. Physical processes in GDLs, in addition to diffusive transport, include bypass flow induced by in-plane pressure difference between neighboring channels [161,162], through-plane flow induced by mass source/sink due to electrochemical reactions $[163,164]$, heat transfer [165,166] like the heat pipe effect [167], two-phase flow [167-170], and electron transport [102,171].

Transport inside GDLs, closely related to the GDL structural feature, plays an important role in fuel cell energy conversion. GDLs are usually $100-300 \mu \mathrm{m}$ thick. A popular GDL material is the carbon fiber based porous media: the fibers are either woven together to form a cloth, or bonded together by resins to form a paper, see Fig. 25. Ralph et al. [172] showed that the carbon cloth exhibits a better performance than the paper at high current $\left(>0.5 \mathrm{~A} \mathrm{~cm}^{-2}\right)$ with internal humidification. Wang et al. [173] characterized the structural features of the carbon cloth and paper and provided an explanation for the distinct performance observed, see Fig. 26. Several stochastic models have been developed to reconstruct the GDL micro structure. Wang et al. further presented detailed DNS to disclose the transport phenomena of mass, reactant, electron, and heat occurring inside the GDL, see Figs. 27 and 28 [174]. Wang and co-workers [175-177] applied the LBM (Lattice Boldtzman method) to study the meso-scale transport of liquid water, based on detailed GDL structure either from stochastic modeling or experimental imaging (e.g. X-ray micro-CT). The LBM is a powerful technique for simulating transport and fluid flows involving interfacial dynamics and complex geometries. It is based on first principles and considers flows to be composed of a collection of pseudo-particles residing on the nodes of an underlying lattice structure. The LBM formula is different from the conventional $\mathrm{Na}$ vier-Stokes equation, which is based on macroscopic continuum description. Comparing with VOF (volume of fluid) methods, the LBM is advantageous in simulating multi-phase flows because of its inherent ability to incorporate particle interactions to yield phase segregation and thus, eliminate explicit interface tracking. An example of prediction using the LBM is shown in Fig. 28. Using 3D tomography image, Becker et al. [178,179] applied a simplified model to determine permeability, diffusivity, and thermal conductivity as a function of liquid saturation. 


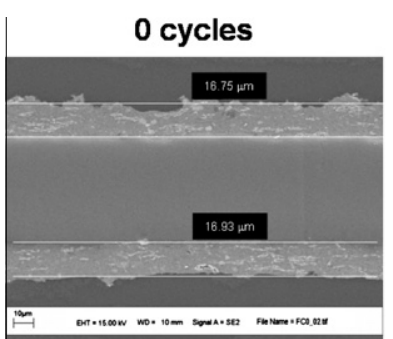

2000 cycles

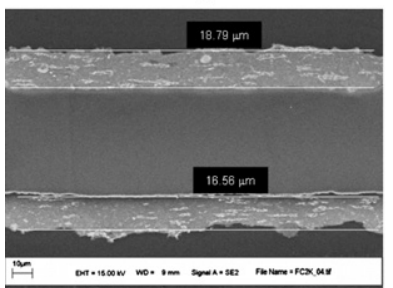

500 cycles

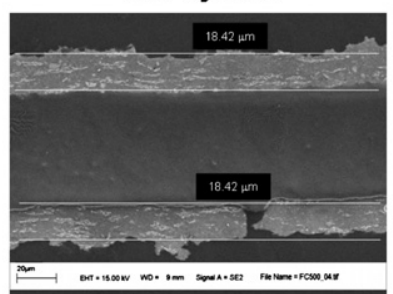

5000 cycles

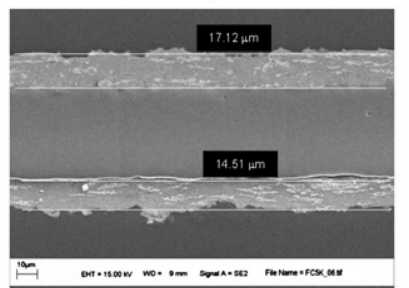

1000 cycles

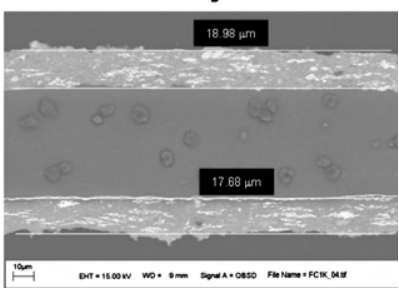

10000 cycles

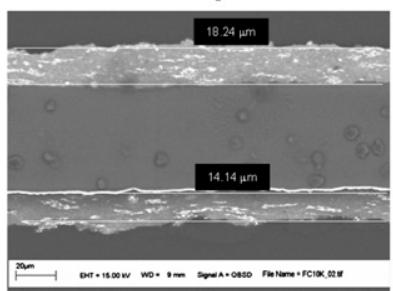

Fig. 24. SEM micrographs of aged MEAs in potential cycling from 0.1 to $1.2 \mathrm{~V}$. Cathode shown on the bottom in each image [105].

Multi-phase flow, originated from the water production by the ORR, is critical to fuel cell water management. The excessive presence of liquid water hinders the reactant delivery to the catalyst sites, increasing the concentration polarization. This is generally referred to "flooding" phenomenon, which can raise concerns of durability and performance reduction due to reactant starvation. The GDL materials are usually rendered hydrophobic to facilitate liquid water drainage. Polytetrafluoroethylene (PTFE, a.k.a. DuPont's Teflon ${ }^{\mathrm{TM}}$ ) is frequently adopted to modify the GDL wettability. Benzinger et al. [180] presented a study on the PTFE loading in various DM materials and their impacts on water transport. Sinha and Wang [181] used a pore-network model of GDLs, and found that liquid water preferentially flows through the connected hydrophilic pore network of a GDL with mixed wettability, see Fig. 28. Pore-network models have also been employed by Gostick et al. [182]. A number of macroscopic models on two-phase flow have been developed to capture the two-phase characteristics in GDLs $[68,183-185]$. They mostly treat the GDL as a uniform hydrophilic or hydrophobic medium. The capillary pressure is usually expressed as a function of saturation via the Leverett function in the literature, and the capillary-pressure gradient is expressed as a function of the saturation gradient. But it should be pointed out
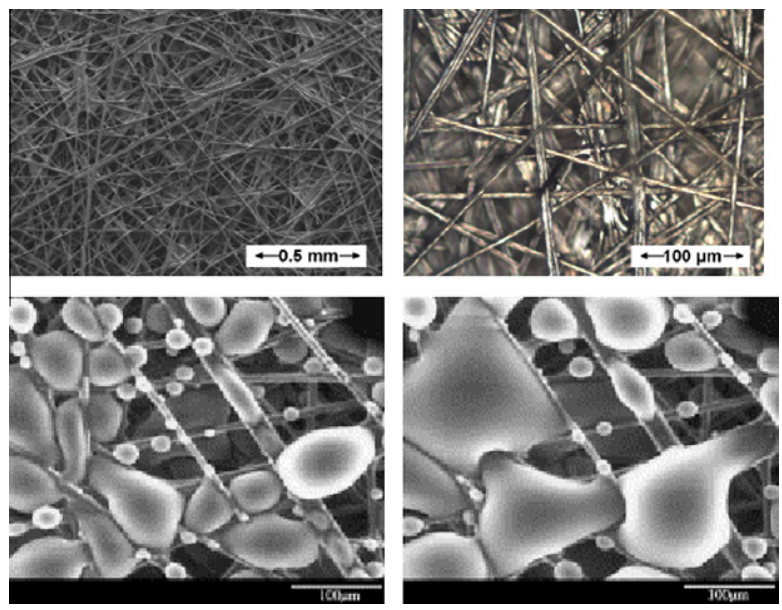

Fig. 25. The carbon paper DM (above) [174]; and two consecutive environmental scanning electron micrographs (ESEM) of a diffusion medium exposed to watervapor saturated atmosphere (below) [170]. that the Leverett function was originally developed to describe liquid-water transport in soils; as such, it is not directly applicable to liquid-water transport in the GDLs of a PEM fuel cell due to their unique pore characteristics.

To improve the multi-phase, particularly liquid, flow characteristics, the MPL can be added and placed between the GDL and CL. This layer is composed of carbon black powder with fine pore structure. Studies have showed that adding MPLs exhibit a better water drainage characteristics and fuel-cell performance. Gostick et al. indicated that the saturation in the GDL for water breakthrough is drastically reduced from ca. $25 \%$ to ca. $5 \%$ in the presence of MPL [186]. Pasaogullari et al., Weber and Newman, Wang and Chen proposed that the MPL acts as a valve that drives water away from electrodes to reduce the electrode flooding [187-189]. At the MPL-GDL interface under certain conditions, the following relation was employed by Passagullari et al. [188] and Wang et al. [189]:

$\sigma \cos \left(\theta_{c}^{G D L}\right)\left(\frac{\varepsilon^{G D L}}{K^{G D L}}\right)^{1 / 2} J(s)=P_{c}^{G D L}=P_{c}^{M P L}=\sigma \cos \left(\theta_{c}^{M P L}\right)\left(\frac{\varepsilon^{M P L}}{K^{M P L}}\right)^{1 / 2} J(s)$

The above adopts the Leverett relation. Generally, the MPL porosity and mean pore-size are much smaller than that of the GDL. In their experimental efforts, Mukundan et al. and co-workers at LANL employed the neutron radiography to investigate the impacts of PTFE loadings on the water content within both GDLs and MPLs, and indicate that lower PTFE loadings in MPLs may show better performance and lower transport resistance [190]. Hickner et al. also applied neutron imaging to quantify the liquid water content within MPLs and GDLs [191]. Neutron imaging on liquid water in PEMFCs was also performed by Kramer et al. [192] who presented detection of liquid accumulation in flow field and GDL under various operating conditions. Lehmann et al. [193] further outlined the applications of neutron imaging to fuel cell and other research fields. It should be pointed out that Eq. (8) is valid only when the properties of GDL and MPL are similar and it may need to be modified when the properties of GDL and MPL are significantly different [194]. Indeed, what conditions should be specified at the GDL/MPL interface is still under active research.

Though fundamental models have been developed to understand the liquid flow inside DMs, the newly experimental data from high-resolution neutron imaging indicate a big discrepancy with a model prediction [195]. In reality, the GDL is highly 

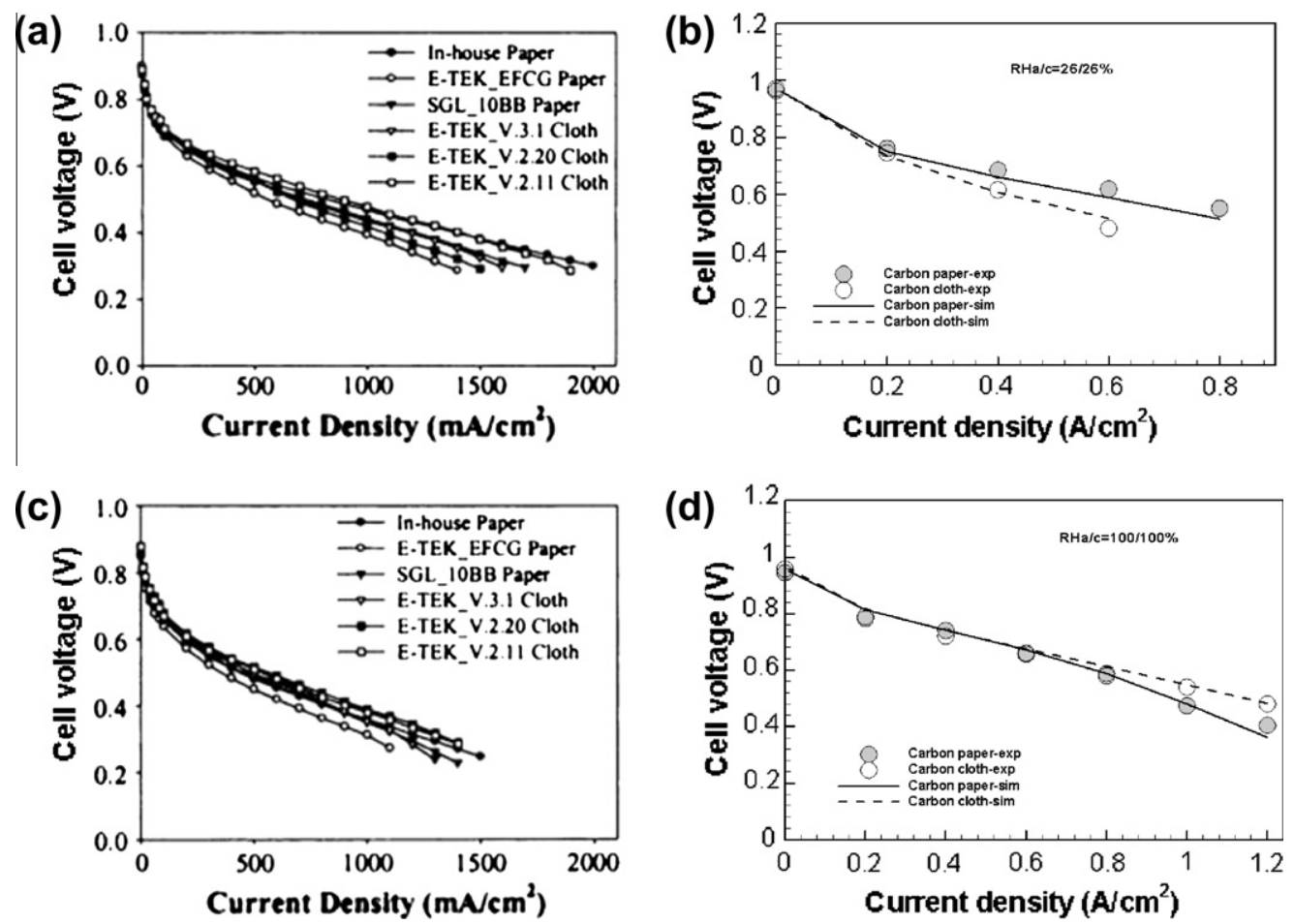

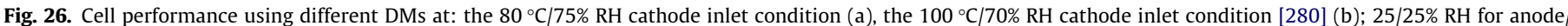
cathode and $80^{\circ} \mathrm{C}(\mathrm{c})$; and $100 / 100 \% \mathrm{RH}$ and $80^{\circ} \mathrm{C}$ [173] (d).
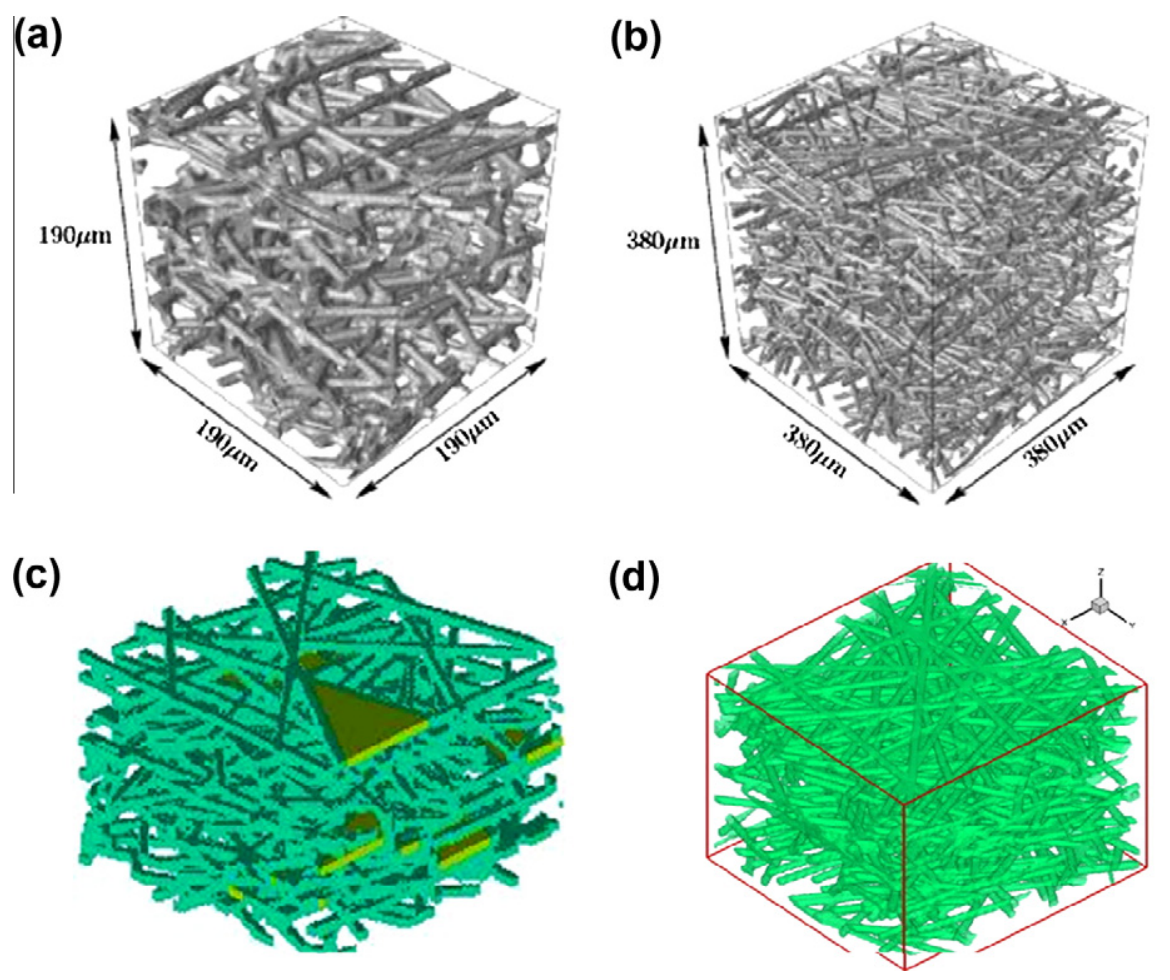

Fig. 27. Visualized cutout of the reconstructed Toray090 (a); SGL10BA from [281] (b); from [282] (c); and from [283] (d).

non-uniform in terms of its hydrophilic and hydrophobic properties; in other words, some areas in the GDL where carbon is present are highly hydrophilic whereas other areas where Teflon is present are highly hydrophobic, which is not accounted for in the current macroscopic approach. Further studies are needed in characterizing the pore-size distribution as well as hydrophilicity and hydrophobicity distributions and using this information to develop pore-level models. This type of work can aid in enabling the 


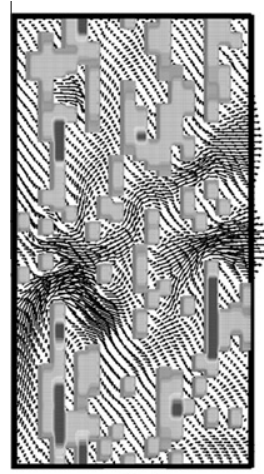

(a)

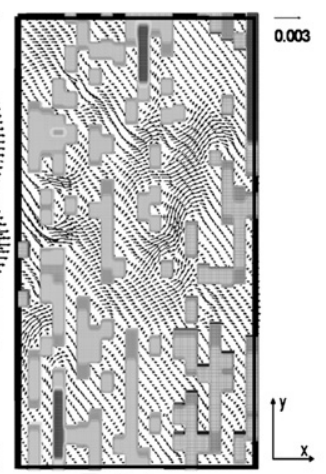

(b) (c)

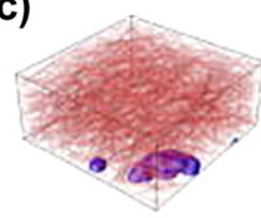

(e)

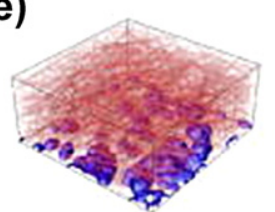

(d)

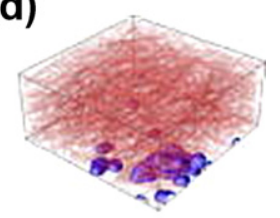

(f)

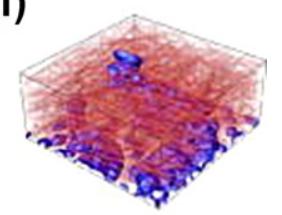

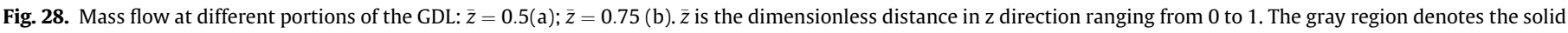
with the light gray being the carbon fibers and the dark the binders. [282]; and liquid water distribution pattern from the drainage simulation [281] (c)-(f).

realistic and accurate simulation of liquid water and gas transport through the GDLs with highly non-uniform pore-sizes and wettability and complete understanding how GDL properties influence fuel-cell performance.

In addition, the macroscopic two-phase flow approach has been widely employed (see, e.g., Wang et al. [196], Natarajan and Nguyen [197], Mazumder and Cole [198], Pasaogullari and Wang [169]) to model liquid-water transport through the GDL and MPL. In this approach, capillary pressure is usually expressed as a function of saturation via the Leverett function [199]. However, as mentioned previously, adoption of the Leverett function likely raises inaccuracy because it was formulated originally for water transport in soils, therefore a new correlation is required to build the relationship between the capillary pressure and saturation for fuel cell GDLs. Two types of the information are highly needed: One is experimentally measured capillary pressure as a function of saturation as demonstrated by Ohn et al. [200], Nguyen et al. [201], Fairweather et al. [202], and Sole and Ellis [203] (this will address the concern that the Leverett function was originally developed for describing gas and liquid transport in soils and rocks, which have vastly different pore-size distribution and shape as compared with those in carbon paper or cloth GDLs). Another is the local capillary pressure as a function of pore radius and contact angle, which can be used to account for non-uniform hydrophilic and hydrophobic properties.

In addition, GDLs may be subjected to degradation after longterm operations, such as wettability change due to PTFE loss and fiber breakage arising from freeze/thaw cycling. The surface properties were evaluated by Wood et al. [204] who presented singlefiber contact-angle and surface-energy data of a wide spectrum of GDL types to delineate the effects of hydrophobic postprocessing treatments [204]. Wood and Borup further presented the cathode $\mathrm{CL}$ and GDL mass-transport overpotentials and analyzed the changes in a durability test [205]. They found little increase in the GDL mass-transport overpotential during the first period of about $500 \mathrm{~h}$, but a substantial increase during the second period of approximately $500 \mathrm{~h}$. Though Mukherjee et al. [206] presented a numerical study on the impact of GDL durability on fuel-cell performance, modeling degradation mechanisms is still lacking and remains a challenge at present, and thus requires further studies.

\subsection{Gas flow channels, cooling channel, and bipolar plates}

Gas flow channels (GFCs) are important components of PEM fuel cell and they supply and distribute hydrogen fuel and oxygen reactant for reactions and remove byproduct water. They are located within the bipolar plates with a typical cross-section dimension of around $1 \mathrm{~mm}$. Insufficient supply of reactants will lead to hydrogen/oxygen starvation, reducing cell performance and durability. Bipolar plates (BP) provide mechanical support over DMs and conductive passages for both heat and electron transport. Fabrication of BPs, together with GFCs, may contribute an important portion of a fuel cell cost [1]. BP degradation, such as the metal plate corrosion and graphite crack, may happen and reduce fuel cell lifetime. Cooling channels can be machined within the bipolar plates, and is essential for the waste heat removal for large-scale fuel cell. Local hot spot formation can degrade the membrane and cause pin-hole or crack formation. Comprehensive reviews on flow fields and bipolar plates were provided by Wilkinson and Vanderleeden, EG\&G Technical Service, and Li and Sabir [207-209].

In GFCs, partially or fully humidified hydrogen and air are injected into anode and cathode, respectively. Several types of flow fields have been developed, they are parallel, serpentine, pin-type, interdigitated, and porous media designs [71,209]. A zigzag flow field with different aspect ratio has also been proposed and studied [210]. Jeon et al. [211] investigated single channel, double channel, cyclic-single channel, and symmetric-single channel patterns, and found that fuel-cell performance varies in different configurations. Karvonen et al. [212] numerically investigated parallel channel flows and developed a strategy for a small variation ( $2 \%)$ of flow velocity among channels. Perng et al. [213] indicated that a rectangular cylinder installed transversely in the flow channel can enhance fuel-cell performance. Perng and Wu [214] showed that baffle blockage in tapered channels provides a better convection and a higher fuel flow velocity and enhances cell performance. Several studies also investigated the cross-section dimension of GFCs. Inoue et al. [215] examined channel height and found that shallow channels may enhance oxygen transport to electrodes. Wang [216] analyzed the channel in-plane dimension by examining heat and electron transport characteristics. Wang et al. [217] investigated the channel aspect ratio for serpentine flow field.

Convection is the dominant force for species transport in a GFC, and the flow has been customarily treated using the single-phase approach: either considering the vapor phase as superly saturated or treating it as mist flow - neither of these two approaches describe reality of flow in GFCs. The streams frequently fall in the two-phase regime due to water addition from the ORR. Liquid may block channels, hampering reactant supply and unstable fuel cell operation [216,218-221]. Fig. 29 shows cell voltage variation over time (the blue ${ }^{1}$ or higher trace) for five different air stoichiometric ratios $(\xi)$ at the current density of $0.2 \mathrm{~A} / \mathrm{cm}^{2}$ in a $14 \mathrm{~cm}^{2}$ PEM fuel cell. It can be seen that the cell voltage becomes oscillatory with a magnitude of $\sim 120 \mathrm{mV}$ at the stoichiometry of 2 . Thus, cathode

\footnotetext{
${ }^{1}$ For interpretation of color in Figs. 1-17, 19-21, 23, 25, 27-31, 33 the reader is
} referred to the web version of this article. 


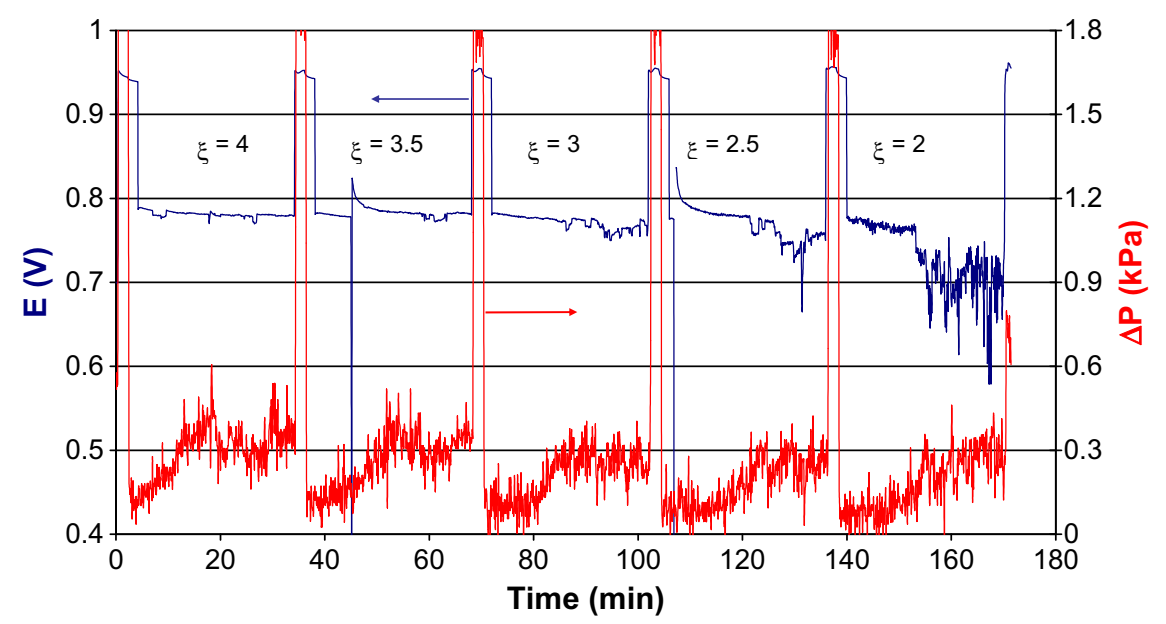

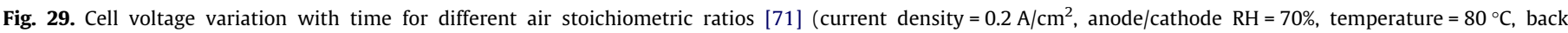
pressure $=150 \mathrm{kPa}$ ).

flooding results in a performance loss $(\sim 120 \mathrm{mV})$ that completely negates any potential improvement from catalyst development: for instance, a 4-fold increase in catalytic activity yields only $\sim 45 \mathrm{mV}$ gain in cell voltage [71]. Moreover, the voltage fluctuation induced by channel flooding may set up a voltage cycling at high potentials, which could result in serious durability issues. Due to the important role of liquid water in the channel flow, the wettability of the GFC wall, i.e. the hydrophilicity or hydrophobicity, may have great impacts on the channel two-phase flow: hydrophilic GFC walls seem to be favored by practitioners since they facilitate the formation of a thin liquid-water film and provide a steady flow of air (and thus $\mathrm{O}_{2}$ ) to reaction sites, whereas the hydrophobic GFC walls can result in unsteady PEMFC operation.

Modeling the channel two-phase flow in fuel cell is numerically very challenging. Wang et al. envisaged the mini-channels as structured and ordered porous media [71]. A two-phase channel flooding model was developed based on the two-phase mixture description. Three fundamental issues critical to the channel design are explained, they are water buildup, channel heterogeneity, and flow maldistribution. Basu et al. [222,223] also developed a two-phase model to study the flow maldistribution in fuel cell channels. Wang further proposed a concept of porous-media channels, see Fig. 30, and examined the characteristics of reactant flows, heat transfer, species transport, and two-phase transport [216]. Liquid profile along the channel was analytically obtained using a two-fluid flow model. Several studies were conducted to investigate the liquid transport using the volume of fluid (VOF) [224226] and LB (Lattice Boltzmann) methods [227]. Most of them focused on the dynamics of liquid droplets, which will be detailed in the next sub-section. However, modeling two-phase behavior in channels that can be incorporated to a full fuel cell model still remains as a challenge due to lack of efficient numerical methods to track the two-phase interface and capture multi-component transport. Further study is required to characterize the two-phase flow in the full regime of fuel cell operation such as slug and slug-annulus transition. Also models fully couples the channel two-phase flow, transport in the porous DM, and the electrochemical reaction kinetics in the MEA are highly needed.

The bipolar plates (BPs) contribute a primary portion of fuel cell weight. The DOE target on the BP weight is $<0.4 \mathrm{~kg} / \mathrm{kW}$ by 2015 and Adrianowycz showed their development status in 2009 is $0.57 \mathrm{~kg} / \mathrm{kW}$ [228]. A popular BP material is the non-porous graphite, which is chemically stable and highly conductive to electrons and heat. There are several disadvantages such as its brittleness and costly manufacturing associated with using graphite. The DOE cost targets are set at $\$ 5 / \mathrm{kW}$ for 2010 and $\$ 3 / \mathrm{kW}$ for 2015 for BPs. Other materials under development include metals such as aluminum, iron [229], stainless steel [230-232], titanium, nickel [233]), polymer composites [234,235], silicon (for DMFC micro-fuel cells, see Ref [236]), and carbon-based materials [49]. Metallic alloys can be ideal materials for BPs because they are amenable to low-cost/high-volume manufacturing, offer high thermal and electrical conductivities, and can be made readily in thin sheet or foil form ( $<1 \mathrm{~mm}$ thick) for high fuel cell power densities. Stamp/molding methods are promising to significantly reduce cost comparing with the machined graphite bipolar plates [237]. However, metals

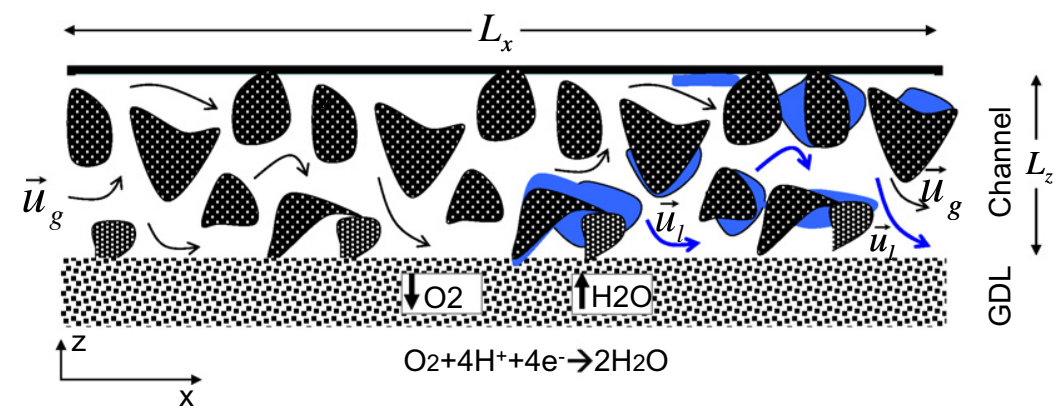

Fig. 30. Configuration of a porous media channel and schematic of the internal two-phase flow [284]. 
may be subject to corrosion in PEMFC operation environments. One method to improve the corrosion resistance of metallic BPs is through coatings. However, there might be issues such as pinhole defects, which result in local corrosion and metallic ion contamination of the membrane and must be resolved. Brady et al. [238] investigated preferential thermal nitridation to form pinhole free $\mathrm{Cr}$-nitrides protecting layer for BPs. They also considered $\mathrm{Fe}-\mathrm{Cr}$ base alloys in a later study [239].

Cooling channels must be added to keep fuel cells at their optimal temperature when a large amount of waste heat is generated. Cooling channel designs have been received relatively small attention in past comparing with other components. Wang and Wang shows the cooling channel design and control can be optimized for better water/thermal management [240]. Yu et al. and Inoue et al. also presented a study on cooling channels or units for PEM fuel cell $[241,242]$.

\subsection{GDL/GFC interface}

At the cathode GDL/GFC interface, oxygen transports towards the electrode where it reacts with protons and electrons to produce water, which eventually enters the channel. The interfacial resistance for reactant transport will be significantly increased due to the presence of liquid water. Optical visualizations, see Fig. 31, showed that liquid water exists as droplets on the GDL surface, taken away by the gas flow $[216,218,219,221,243,244]$ or attach to the channel wall [216]. The behavior of liquid water droplets at the GDL/GFC interface consists of three sub-processes: (1) transport from the catalyst layer to the GDL/GFC interface via capillary action; (2) removal at the GDL/GFC interface via detachment or evaporation; and (3) transport through the GFC in form of films, droplets and/or vapor. The growth and detachment of water droplets are influenced by two factors: the operating conditions of the fuel cell and the physical (e.g., surface roughness) and chemical (e.g., wettability) material characteristics of the GDL surface (e.g. in terms of the hydrophilic/hydrophobic properties). Chen et al. [245] pioneered the analysis of droplet instability and detachment and they indicated that the static contact angle $\left(\theta_{\mathrm{s}}\right)$ and contact angle hysteresis (the difference between advancing and receding contact angles, i.e., $\left.\theta_{A}-\theta_{R}\right)$, are both important parameters in determining the force required to move a droplet across a surface. Instability diagrams were developed to explore the operating conditions under which droplets become unstable (an example of such instability diagram is shown in Fig. 32). Unstable conditions are desirable to operate the fuel cell under such conditions that droplets can be removed instantaneously from the GDL/GFC interface so as to prevent blockage of pathways for oxygen transport to the

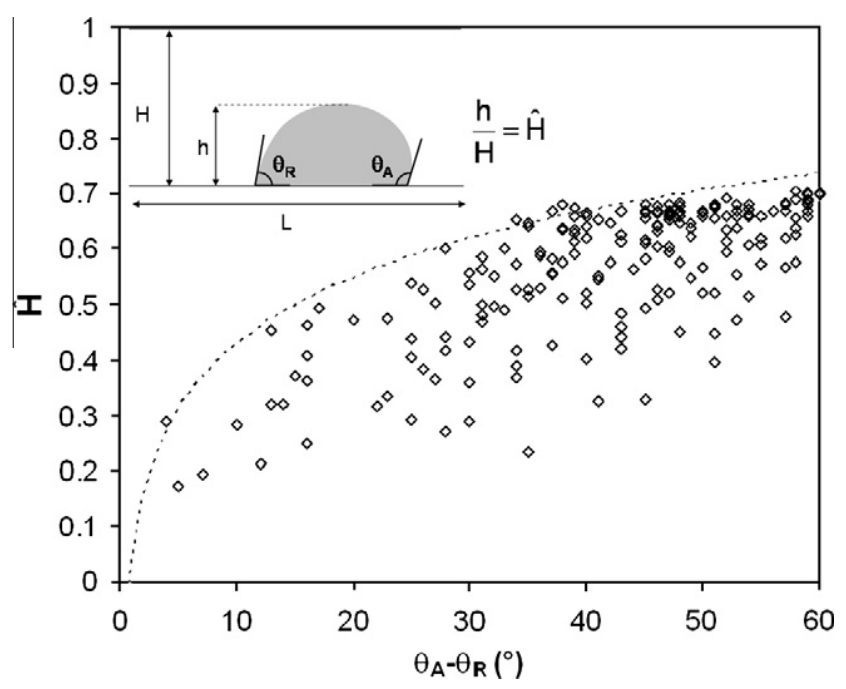

Fig. 32. Droplet instability diagram for an air flow velocity of $800 \mathrm{~cm} / \mathrm{s}, L=7 \mathrm{~cm}$ and $\theta_{\mathrm{s}}=140^{\circ} ;(\diamond)$ experimental data points, (- - ) upper bound of experimental data [105].

three-phase reaction sites. In addition, the VOF-based modeling has also been conducted to investigate the droplet dynamics at the interface [225,246-249]. The droplets on the GDL surface increases reactant transport resistance into the GDL as well as liquid flow inside. Meng and Wang and Wang et al. used liquid coverage to account for the droplet presence in their study $[173,250]$. Further work of interests includes development of 3D fundamental models to predict droplet behaviors at the interface, particularly the impact of GDL surface properties on droplet dynamics. Given the droplets appear randomly at the GDL surface, statistical methods might be adopted to evaluate the portion of area covered by liquid. Also the GFC-GDL interface bridges the transport in channels and GDL, therefore a fundamental understanding of this connection and a mathematical model that can describe the connection will be highly needed. A simplified explicit mode was developed by Chen [251] for analyzing water-droplet detachment in the inertia-dominating regime. Chen also carried out 3-D numerical simulation of droplet detachment in the inertia-dominating regime using the VOF method. A realistic water-flux boundary condition at the GDL/GFC interface was also discussed. Further detailed study on more realistic droplet emerging/detachment in a real fuel cell channel, a wide range of regimes, as well as its coupling with the transport and electrochemical reaction is highly needed.

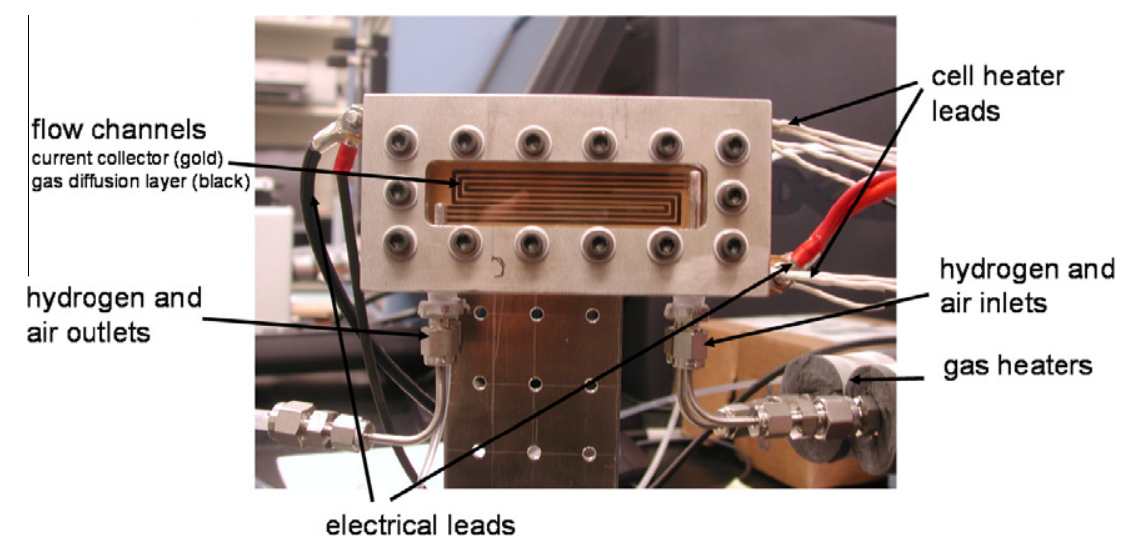

Fig. 31. Specially-designed, transparent, fuel cell direct-visualization apparatus [105]. 


\subsection{Stack}

A single fuel cell is only able to produce a certain voltage and current. In order to obtain a higher voltage and current or power, fuel cells are connected in either series or parallel, called stacks, see Fig. 33. At the stack level, water and heat management becomes more complex due to the interactions of constituent sub-cells. Individual cells communicate in many ways in a stack. One is the electrical connection, i.e. the electrical current flows through all the individual cells in a series stack, therefore a local high electronic resistance will significantly affect the stack performance. Another one is through flow field. In practice, several fuel cells share one inlet/outlet manifold in a stack. Therefore, a fuel cell with high flow resistance receives fewer amounts of the reactants, causing local reactant starvation (which further leads to cell performance decay and material degradation). A third one is heat transfer connection. A fuel cell exhibiting a larger thermal resistance or exposing to insufficient cooling will subject to a higher temperature and disposes its extra waste heat to neighboring fuel cells. Such local hot fuel cell may reduce cell performance and raise concerns of material degradation. Detailed fundamental study at the stack level becomes challenging. Most studies only considered a simplified stack model, e.g. Promislow and Wetton [252] developed a model of steady-state thermal transfer in stacks. The model is appropriate for straight coolant channel unit cell designs and considers quantities averaged over the cross-channel direction, ignoring the impact of the gas and coolant channel geometries. Kim et al. [253] developed an electrical interaction model for stacks and validated it using two types of anomalies. The unit cells are described by simple, steady-state, $1+1$-dimensional models appropriate for straight reactant gas channel designs. Berg et al. [254] also presented a similar stack approach with the unit cells described by one dimensional models appropriate for straight reactant gas channel designs. Karimi et al. used a flow network to determine the pressure and flow distributions [255]. The results were incorporated into the individual cell model developed by Baschuk and Li [256]. Chang et al. used a flow distribution model to examine the sensitivity of stack performance to operating conditions (inlet velocity and pressure) and design parameters (manifold, flow configuration and friction factor) [257]. Park and Li presented a flow model and concluded that flow uniformity can be enhanced by a large manifold [258]. Chang et al. [257] developed a stack model incorporating flow distribution effects and a reduced-dimension unit cell model. The mass and momentum conservation are applied throughout the stack. Flow splitting and recombination are considered at each tee junction, while along the unit cell channels, reactant consumption and byproduct production are accounted for. Yu et al. proposed a water and thermal management model of a Ballard fuel

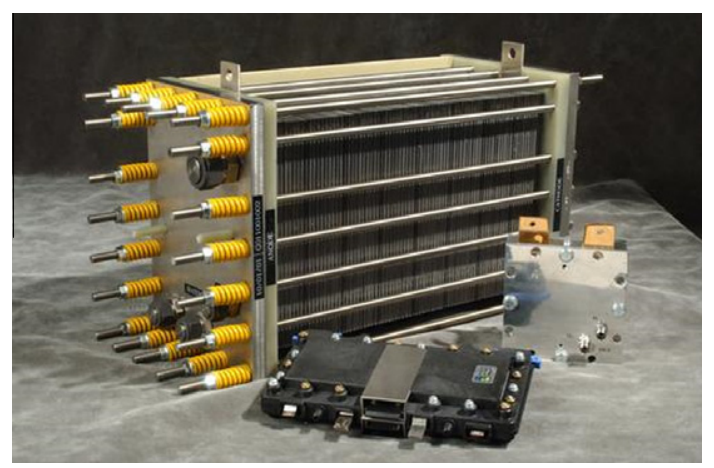

Fig. 33. A $5 \mathrm{~kW}$ fuel cell manufactured by PlugPower (large cell), $25 \mathrm{~W}$ fuel cell (three cell stack) manufactured by H2ECOnomy (smaller silver cell), $30 \mathrm{~W}$ fuel cell manufactured by Avista Labs [285]. cell stack which takes a set of gas input conditions and stack parameters such as channel geometry, heat transfer coefficients, and operating current [259]. The model can be used to optimize the stack thermal and water management. Chen et al. numerically investigated the flow distribution in a stack, and concluded that the channel resistance, manifold dimension and gas feed rate may affect flow distributions [260]. Chang et al. [261] proposed separation of the complex model into computationally manage-able pieces. The computational method is backed by some simplified analysis and a convergence study.

At the stack level, the following issues are also considered as important areas requiring further study: they are optimization of stack system (e.g. stack design and reactant manifold); fuel processing subsystem (fuel management, reformer, steam generator, shift reactor, etc); power and electric subsystem; thermal management subsystem (cooling, heat exchanger); and ancillary subsystem (air supply, water treatment, safety, monitoring, ventilation fans, misc). Modeling and simulation of PEM fuel cell stacks provide a powerful tool for stack design and optimization. Comprehensive models that fully couple the reactant flow in the GFC and manifolds and the transport within fuel cell in conjunction with electrochemical reaction are highly needed. One critical part is the two-phase flow in the complex flow field of stacks, which is essential to capture the flow maldistribution phenomena. In addition, computational studies based on a comprehensive model are still computationally too expensive at current so efficient numerical schemes are in need.

\section{Summary and concluding remarks}

The latest status of PEM fuel cell technology and its applications has been reviewed, and the needs on fundamental research have been discussed. PEM fuel cells have the potentials to reach $\sim 60 \%$ in electrical energy conversion or overall $80 \%$ in co-generation of electrical and thermal energies with $>90 \%$ reduction in major pollutants. The following three major PEMFC applications were discussed, i.e. automobile, portable, and stationary applications. To date, approximately 75,000 fuel cells have been shipped worldwide and during the last year (2009) alone about 24,000 fuel cells were shipped. In the US, currently there are over 200 fuel-cell vehicles and 20 buses that are being deployed.

Two primary barriers to the world-wide commercialization of PEM fuel cell technology were explained: durability and cost. Significant progresses have been made in the past years, and the current status of PEMFC technology in these two aspects can be summarized as follows:

(1) The DOE target of durability lifetime is greater than $5000 \mathrm{~h}$ for transportation applications by 2015 and $40,000 \mathrm{~h}$ for stationary applications by 2011 . Currently, $\sim 2500$ h of lifetime was achieved in 2009 for transportation and 20,000 h was obtained in 2005 for stationary fuel cells.

(2) The DOE target of cost is $\$ 45 / \mathrm{kW}$ in 2010 and $\$ 30 / \mathrm{kW}$ in 2015 for transportation applications and $\$ 750 / \mathrm{kW}$ by 2011 for stationary applications. The current cost is $\$ 61 / \mathrm{kW}$ in 2009 for transportation fuel cells.

To further overcome the barriers to the wide deployment of fuel cells, fundamental breakthroughs are needed. This review briefly discusses the role and summarizes the needs on fundamental research as well as the associated challenges. Aspects of materials development, acquisition of fundamental knowledge, and development of analytical models and experimental tools are required. Improvement on catalyst, MEA components, and bipolar plates 
are particularly important for overcoming the two major commercialization barriers (i.e., durability and cost).

Specially, for membrane and catalyst layer (which consist of the MEA), both require significant further research in order to identify and develop alternative cost-effective materials. Correlations of membrane properties to performance for general polymer electrolyte materials are much in need. MEAs with better degradation resistance and low Pt loading are critical to achieving the DOE cost and lifetime targets. For GDLs and MPLs, fundamental understanding of liquid-water behaviors in these components is required, in particular on the effects of the micro structure of the media and the proper combination of hydrophobicity and hydrophilicity. For bipolar plates and GFCs, advanced fabrication methods are needed to reduce the cost of the plates and improve their corrosion resistance. Lastly, fundamental knowledge of liquid droplet removal at the GDL/GFC interfaces and two-phase flow in micro-/mini-channels is challenging to obtain, but such knowledge is in great urgent need in order to develop optimized GDL materials and GFC designs that can ensure efficient water removal and reactant supply and avoid flow maldistribution and thus maintain high fuel-cell performance.

\section{References}

[1] Papageorgopoulos D. DOE fuel cell technology program overview and introduction to the 2010 fuel cell pre-solicitation workshop in DOE fuel cell pre-solicitation workshop. Department of Energy, Lakewood, Colorado; 2010.

[2] Wand G. Fuel cell history, Part One. 14

[3] Appleby AJ, Yeager EB. Solid polymer electrolyte fuel cells (SPEFCs). Energy 1986;11(1-2):137-52.

[4] Raistrick ID. Modified gas diffusion electrode for proton exchange membrane fuel cells. In: Proceedings of the symposium on diaphragms, separation, and ion-exchange membranes. Ponnington (NJ): Electrochemical Society; 1986.

[5] Gittleman C, DM, Jorgensen S, Waldecker J, Hirano S, Mehall M. Automotive fuel cell R\&D needs. In: DOE fuel cell pre-solicitation workshop. Department of Energy, Lakewood, Colorado; 2010.

[6] Garche J, Jorissen L. PEMFC fuel cell. In: Vielstich W, Gasteiger H, Lamm A editors. Handbook of fuel cells: fundamentals, technology and applications. John Wiley \& Sons, Ltd.; 2003.

[7] Geiger S, Copper MAJ. Fuel cell small stationary market survey. Fuel Cell Today 2003.

[8] EERE UD. Hydrogen, fuel cells \& infrastructure technologies program multiyear research, development and demonstration plan. In: EERE D, editor. 2007 p. 24.

[9] Pander J. Hamburg speeds up preparation for fuel-cell cars. In: Spiegel. SPIEGELnet GmbH Hamburg; 2009.

[10] DeMatio J. Kia's big fuel cell plans. In: Automobile magazine; 2009.

[11] Toyota, Toyota advanced fuel cell hybrid vehicle completes Government Field Evaluation. In: PRNewswire; 2009.

[12] Zhang $S$ et al. A review of accelerated stress tests of MEA durability in PEM fuel cells. Int J Hydrogen Energy 2009;34(1):388-404.

[13] Borup R, et al. PEM fuel cell durability. 2008 DOE hydrogen program review June $9-13,2008, \quad 5 . \quad<$ http://www.hydrogen.energy.gov/pdfs/review08/ fc_26_borup.pdf>.

[14] Schmittinger W, Vahidi A. A review of the main parameters influencing longterm performance and durability of PEM fuel cells. J Power Sources 2008;180(1):1-14.

[15] Borup R et al. Scientific aspects of polymer electrolyte fuel cell durability and degradation. Chem Rev 2007;107(10):3904-51.

[16] Wood DL, Borup RL. In: Buchi MIFN, Schmidt TJ, editors. Polymer electrolyte fuel cell durability. New York: Springer; 2009. p. 159.

[17] DOE. Hydrogen and fuel cell activities, progress, and plans: report to congress; January 2009, 4. <http://www.hydrogen.energy.gov/pdfs/ epact_report_sec811.pdf $>$.

[18] Directed technologies I. Mass production cost estimation for direct H2 PEM fuel cell systems for automotive applications: 2008 update 2009. p. 10.

[19] DOE-EERE. Fuel cell technology challenges; 2008. <http:// www1.eere.energy.gov/hydrogenandfuelcells/fuelcells/fc_challenges.html>.

[20] Lipman T, Sperling D. Market concepts, competing technologies and cost challenges for automotive and stationary applications. In: Vielstich W, Gasteiger H, Lamm A, editors. Handbook of fuel cells: fundamentals, technology and applications. John Wiley \& Sons, Ltd.; 2003. p. 1318-28.

[21] McNicol BD, Rand DAJ, Williams KR. Fuel cells for road transportation purposes - yes or no. J Power Sources 2001;100(1-2):47-59.

[22] Stumper J, Stone C. Recent advances in fuel cell technology at Ballard. J Power Sources 2008;176(2):468-76.

[23] Kazim A. Introduction of PEM fuel-cell vehicles in the transportation sector of the United Arab Emirates. Appl Energy 2003;74(1-2):125-33.
[24] Jones, R. Honda FCX a step forward for fuel-cell cars. MSNBC 2007. <http:// www.msnbc.msn.com/id/21796636/>.

[25] Vann M. Chevrolet project driveway fuel cell program passes 1 million miles this week. GM fastlane blog; 2009 <http://fastlane.gmblogs.com/archives/ 2009/09/chevrolet_project_driveway_fuel_cell_program_passes_1_million_ miles_this_week.html> [02.12.09].

[26] Jerram LC. 2009 Light duty vehicle survey. Fuel Cell Today 2009.

[27] Haraldsson K, Folkesson A, Alvfors P. Fuel cell buses in the Stockholm CUTE project - first experiences from a climate perspective. J Power Sources 2005;145(2):620-31.

[28] Jerram LC. 2008 Bus survey. Fuel Cell Today 2008.

[29] Adamson K-A, Jerram LC. 2009 Niche transport survey. Fuel Cell Today 2009:11-2.

[30] Hwang JJ, Wang DY, Shih NC. Development of a lightweight fuel cell vehicle. J Power Sources 2005;141(1):108-15.

[31] Beckhaus P et al. On-board fuel cell power supply for sailing yachts. J Power Sources 2005;145(2):639-43.

[32] Siemens. Italian navy orders two more submarines with Siemens fuel cell technology; 2009 <http://w1.siemens.com/press/en/pressrelease/?press=/en/ pressrelease/2009/industry_solutions/iis200910926.htm>

$[10.05 .09$, 02.12.10].

[33] Jerram LC, Dehamna A. 2009 Hydrogen infrastructure survey. Fuel Cell Today 2009.

[34] Wang Y et al. Three-dimensional modeling of hydrogen sorption in metal hydride hydrogen storage beds. J Power Sources 2009;194(2):997-1006.

[35] Collins DJ, Zhou H-C. Hydrogen storage in metal-organic frameworks. J Mater Chem 2007; 17(3154-3160).

[36] Züttel A, Borgschulte A, Orimo S-I. Tetrahydroborates as new hydrogen storage materials. Scripta Mater 2007;56(10):823-8.

[37] Bérubé $V$ et al. Size effects on the hydrogen storage properties of nanostructured metal hydrides: a review. Int J Energy Res 2007;31(67):637-63.

[38] Askri F et al. Optimization of hydrogen storage in metal-hydride tanks. Int J Hydrogen Energy 2009;34(2):897-905.

[39] Butler J. Portable fuel cell survey 2009. Fuel Cell Today 2009.

[40] Narayanan SR, Valdez TI, Rohatgi N. Portable direct methanol fuel cell system. In: Vielstich W, Gasteiger HA, Lamm A, editor. Handbook of fuel cells. John Wiley and Sons; 2003.

[41] Hayase M, Kawase T, Hatsuzawa T. Miniature $250 \mu \mathrm{m}$ thick fuel cell with monolithically fabricated silicon electrodes. Electrochem Solid-State Lett 2004;7(8):A231-4.

[42] Lee S-J, Chen Y-P, Huang C-H. Electroforming of metallic bipolar plates with micro-featured flow field. J Power Sources 2005;145(2):369-75.

[43] Ito T, Kaneko S, Kunimatsu M. Fabrication and characterization of a thin $\mu$ PEMFC with microfabricated grooves on electroformed current collector plate. Electrochem Solid-State Lett 2009;12(11):B154-7.

[44] Hahn R et al. Development of a planar micro fuel cell with thin film and micro patterning technologies. J Power Sources 2004;131(1-2):73-8.

[45] Hsieh SS et al. J Solid State Electrochem 2005;9:121-31.

[46] Cha SW et al. The scaling behavior of flow patterns: a model investigation. J Power Sources 2004;134(1):57-71.

[47] Park BY, Madou MJ. Design, fabrication, and initial testing of a miniature PEM fuel cell with micro-scale pyrolyzed carbon fluidic plates. J Power Sources 2006;162(1):369-79.

[48] Lin P-C, Park BY, Madou MJ. Development and characterization of a miniature PEM fuel cell stack with carbon bipolar plates. J Power Sources 2008;176(1):207-14.

[49] Wang Y et al. Fabrication and characterization of micro PEM fuel cells using pyrolyzed carbon current collector plates. J Power Sources 2010.

[50] SiewHwa C et al. Development of a polymeric micro fuel cell containing lasermicromachined flow channels. J Micromech Microeng 2005;15(1):231.

[51] Müller $\mathrm{M}$ et al. Micro-structured flow fields for small fuel cells. Microsyst Technol 2003;9(3):159-62.

[52] Yeom J et al. Microfabrication and characterization of a silicon-based millimeter scale, PEM fuel cell operating with hydrogen, methanol, or formic acid. Sens Actuat B: Chem 2005;107(2):882-91.

[53] Heinzel A et al. Fuel cells for low power applications. J Power Sources 2002;105(2):250-5.

[54] Henriques T, César B, Branco PJC. Increasing the efficiency of a portable PEM fuel cell by altering the cathode channel geometry: a numerical and experimental study. Appl Energy 2010;87(4):1400-9.

[55] Feitelberg AS et al. Reliability of plug power Gensys(TM) fuel cell systems. J Power Sources 2005;147(1-2):203-7.

[56] Plug power wins award to operate GenSys units in NY homes. Fuel Cells Bull 2009; 2009(9): 6-6.

[57] Plug power, SFO technologies sign GenSys manufacture, supply deal for India. Fuel Cells Bull 2009; 2009(12): 9-9.

[58] Ballard. PEM fuel cell product portfolio; 2009.

[59] Ballard looks to double shipments in 2009 for forklifts, backup power. Fuel Cells Bull 2009; 2009(3): 8-9.

[60] Matsumura I. Toward a low-carbon society with hydrogen energy system development of residential fuel cell system and fuel cell vehicle/hydrogen supply infrastructure. In: 6th Int. hydrogen \& fuel cell expo keynote, Tokyo; 2010.

[61] World's largest 'hydrogen town project' starts in Japan; 2009. <http:// www.japanfs.org/en/pages/028694.html>. 
[62] 6 Japan firms to launch home fuel cell sales; 2009. <http:// www.fuelcelltoday.com/online/news/articles/2009-01/ene-system>.

[63] Wang $C$ et al. Development and performance of $5 \mathrm{~kW}$ proton exchange membrane fuel cell stationary power system. Int J Hydrogen Energy 2005;30(9):1031-4.

[64] Ladewig BP, Lapicque F. Analysis of the ripple current in a $5 \mathrm{~kW}$ polymer electrolyte membrane fuel cell stack. Fuel Cells 2009;9(2):157-63.

[65] Hwang JJ, Zou ML. Development of a proton exchange membrane fuel cell cogeneration system. J Power Sources 2010;195(9):2579-85.

[66] Adamson K-A. Fuel cell today small stationary survey 2009. Fuel Cell Today 2009:11-2.

[67] Gurau V, Mann JA. A critical overview of computational fluid dynamics multiphase models for proton exchange membrane fuel cells. SIAM J Appl Math 2009;70(2):410-54.

[68] Wang C-Y. Fundamental models for fuel cell engineering. Chem Rev 2004:104(10):4727-66.

[69] Siegel C. Review of computational heat and mass transfer modeling in polymer-electrolyte-membrane (PEM) fuel cells. Energy 2008;33(9):1331-52.

[70] Djilali N. Computational modelling of polymer electrolyte membrane (PEM) fuel cells: challenges and opportunities. Energy 2007;32(4):269-80.

[71] Wang Y, Basu S, Wang CY. Modeling two-phase flow in PEM fuel cell channels. J Power Sources 2008;179(2):603-17.

[72] Ma Y-L et al. Conductivity of PBI membranes for high-temperature polymer electrolyte fuel cells. J Electrochem Soc 2004;151(1):A8-A16.

[73] Zhang J et al. High temperature PEM fuel cells. J Power Sources 2006;160(2):872-91.

[74] Smitha B, Sridhar S, Khan AA. Solid polymer electrolyte membranes for fuel cell applications - a review. J Membrane Sci 2005;259(1-2):10-26.

[75] Arcella V et al. Membrane electrode assemblies based on perfluorosulfonic ionomers for an evolving fuel cell technology. Desalination 2006;199(13):6-8.

[76] Merlo L et al. Membrane electrode assemblies based on HYFLON ion for an evolving fuel cell technology - separation science and technology. Separat Sci Technol 2007;42(13):2891-908.

[77] $\mathrm{Li} \mathrm{Q}$ et al. High temperature proton exchange membranes based on polybenzimidazoles for fuel cells. Prog Polym Sci 2009;34(5):449-77.

[78] Atkinson S. Membranes for fuel cells compared in real time. Membrane Technol 2005;2005(1):5-7.

[79] Gierke TD, Hsu WY. Perfluorinated ionomer membranes. In: Eisenberg A Yeager HL, editors. ACS symposium series No. 180. American Chemical Society: Washington, DC; 1982.

[80] Kreuer KD, Rabenau A, Weppner W. Vehicle mechanism, a new model for the interpretation of the conductivity of fast proton conductors. Angew Chem Int Ed Engl 1982;21:208-9.

[81] Kornyshev AA, Kuznetsov AM, Spohr E, Ulstrup J. Kinetics of proton transport in water. J Phys Chem B 2003;107:3351-66.

[82] Marx D et al. The nature of the hydrated excess proton in water. Nature 1999;397(6720):601-4.

[83] Springer TE, Zawodzinski TA, Gottesfeld S. Polymer electrolyte fuel cell model. J Electrochem Soc 1991;138(8):2334-42.

[84] Cappadonia M, Erning JW, Stimming U. Proton conduction of Nafion ${ }^{\circledR} 117$ membrane between $140 \mathrm{~K}$ and room temperature. J Electroanal Chem 1994;376(1-2):189-93.

[85] Wang Y, Mukherjee PP, Mishler J, Mukundan R, Borup RL. Cold start of polymer electrolyte fuel cells: three-stage startup characterization. Electrochim Acta 2010;55:2636-44.

[86] Thompson EL et al. Investigation of low-temperature proton transport in Nafion using direct current conductivity and differential scanning calorimetry. J Electrochem Soc 2006;153(12):A2351-62.

[87] Cappadonia $\mathrm{M}$ et al. Conductance of Nafion 117 membranes as a function of temperature and water content. Solid State Ionics 1995;77:65-9.

[88] Zawodzinski TA et al. A comparative study of water uptake by and transport through ionomeric fuel cell membranes. J Electrochem Soc 1993;140(7):1981-5.

[89] Ren X, Springer TE, Gottesfeld S. Water and methanol uptakes in Nafion membranes and membrane effects on direct methanol cell performance. J Electrochem Soc 2000;147(1):92-8.

[90] Vallieres C et al. On Schroeder's paradox. J Membrane Sci 2006;278(12):357-64.

[91] Freger V. Hydration of ionomers and schroederâ $€^{\mathrm{TM}} \mathrm{s}$ paradox in Nafion. J Phys Chem B 2008;113(1):24-36.

[92] Elfring GJ, Struchtrup $\mathrm{H}$. Thermodynamics of pore wetting and swelling in Nafion. J Membrane Sci 2008;315(1-2):125-32.

[93] Chen KS, Hickner MA. A new constitutive model for predicting proton conductivity in polymer electrolytes. In: ASME proceedings of IMECE'04, paper \#60848; 2004.

[94] Motupally S, Becker AJ, Weidner JW. Diffusion of water in Nafion 115 membranes. J Electrochem Soc 2000;147(9):3171-7.

[95] Ise M, Kreuer KD, Maier J. Electroosmotic drag in polymer electrolyte membranes: an electrophoretic NMR study. Solid State Ionics 1999;125(14):213-23.

[96] Zawodzinski Jr TA et al. Characterization of polymer electrolytes for fuel cell applications. Solid State Ionics 1993;60(1-3):199-211.

[97] Fuller TF, Newman J. Experimental determination of the transport number of water in Nafion 117 membrane. J Electrochem Soc 1992;139(5):1332-7.
[98] Xie G, Okada T. Water transport behavior in Nafion 117 membranes. J Electrochem Soc 1995;142(9):3057-62.

[99] Ge S, Yi B, Ming P. Experimental determination of electro-osmotic drag coefficient in Nafion membrane for fuel cells. J Electrochem Soc 2006;153(8):A1443-50.

100] Ye X, Wang C-Y. Measurement of water transport properties through membrane-electrode assemblies. J Electrochem Soc 2007;154(7):B676-82.

101] Adachi $\mathrm{M}$ et al. Correlation of in situ and ex situ measurements of wate permeation through Nafion NRE211 proton exchange membranes. J Electrochem Soc 2009;156(6):B782-90.

[102] Bernardi DM, Verbrugge MW. A mathematical model of the solid-polymerelectrolyte fuel cell. J Electrochem Soc 1992;139(9):2477-91.

[103] Büchi FN, Wakizoe M, Srinivasan S. Microelectrode investigation of oxygen permeation in perfluorinated proton exchange membranes with different equivalent weights. J Electrochem Soc 1996;143:927-32.

[104] Zawodzinski TA et al. The water content dependence of electro-osmotic drag in proton-conducting polymer electrolytes. Electrochim Acta 1995;40(3):297-302.

105] Chen KS et al. Final report on LDRD project: elucidating performance of proton-exchange-membrane fuel cells via computational modeling with experimental discovery and validation, in SAND2006-6964, Sandia Technical Report; 2006.

[106] Chen KS, Hickner MA. A new constitutive model for predicting proton conductivity in polymer electrolytes. In: Proceedings of 2004 international mechanical engineering congress and exhibits; 2004.

[107] Weber AZ, Newman J. Transport in polymer-electrolyte membranes. J Electrochem Soc 2003;150(7):A1008-15.

[108] Weber AZ, Newman J. Transport in polymer-electrolyte membranes. J Electrochem Soc 2004;151(2):A311-25.

[109] Yu P, Pemberton M, Plasse P. PtCo/C cathode catalyst for improved durability in PEMFCs. J Power Sources 2005;144(1):11-20.

[110] Reiner A et al. Co-sputtering: a novel platinum-carbon catalyst preparation method. In: 3rd European PEFC forum, Lucerne; 2005. Poster 109.

[111] Ismagilov ZR et al. Development of active catalysts for low Pt loading cathodes of PEMFC by surface tailoring of nanocarbon materials. Catal Today 2005;102-103:58-66.

[112] Fernandez JL, Walsh DA, Bard AJ. Thermodynamic guidelines for the design of bimetallic catalysts for oxygen electroreduction and rapid screening by scanning electrochemical microscopy. M-Co (M: Pd, Ag, Au). J Am Chem Soc 2004;127(1):357-65.

[113] González-Huerta RG, Chávez-Carvayar JA, Solorza-Feria O. Electrocatalysis of oxygen reduction on carbon supported Ru-based catalysts in a polyme electrolyte fuel cell. J Power Sources 2006;153(1):11-7.

[114] Rao CRK, Trivedi DC. Chemical and electrochemical depositions of platinum group metals and their applications. Coord Chem Rev 2005;249(56):613-31.

[115] Pharkya P, Alfantazi A, Farhat Z. Fabrication using high-energy ball-milling technique and characterization of Pt-Co electrocatalysts for oxygen reduction in polymer electrolyte fuel cells. J Fuel Cell Sci Techno 2005;2:171-7.

[116] Travitsky $\mathrm{N}$ et al. Nanometric platinum and platinum-alloy-supported catalysts for oxygen reduction in PEM fuel cells. In: 3rd European PEFC forum, Lucerne, Switzerland; 2005.

[117] Wells $\mathrm{P}$ et al., Preparation of $\mathrm{Cr} / \mathrm{Pt} / \mathrm{C}$ catalysts by the controlled surface modification of $\mathrm{Pt} / \mathrm{C}$ using an organometallic precursor. In: 3rd European PEFC forum, Lucerne, Switzerland; 2005.

[118] Xie J et al. J Electrochem Soc 2005;152(1):A104-13.

[119] Debe MK. Advanced cathode catalysts and supports for PEM fuel cells. In: 2010 Hydrogen program annual merit review and peer evaluation meeting. Washington, DC; 2010.

[120] Vante NA, Tributsch H. Energy conversion catalysis using semiconducting transition metal cluster compounds. Nature 1986;323:431-2.

[121] Fernandez JL et al. Pd-Ti and Pd-Co-Au electrocatalysts as a replacement for platinum for oxygen reduction in proton exchange membrane fuel cells. J Am Chem Soc 2005;127(38):13100-1.

[122] Bashyam R, Zelenay P. A class of non-precious metal composite catalysts for fuel cells. Nature 2006;443(7107):63-6.

[123] Bezerra CWB et al. A review of $\mathrm{Fe}-\mathrm{N} / \mathrm{C}$ and $\mathrm{Co}-\mathrm{N} / \mathrm{C}$ catalysts for the oxygen reduction reaction. Electrochim Acta 2008;53(15):4937-51.

[124] Wang B. Recent development of non-platinum catalysts for oxygen reduction reaction. J Power Sources 2005;152:1-15.

[125] Zelenay P. Advanced cathode catalysts. In: 2010 Hydrogen program annual merit review and peer evaluation meeting, Washington, DC; 2010.

[126] Eisman et al. Separators and ion-exchange membranes. Electrochem Soc Proc 1986;86(13):186.

[127] Gottesfeld S, Pafford J. A new approach to the problem of carbon monoxide poisoning in fuel cells operating at low temperatures. J Electrochem Soc 1988;135(10):2651-2

[128] Dhathathreyan KS, Rajalakshmi N. Polymer electrolyte membrane fue cell. Anamaya Publishers; 2006

[129] Mukherjee PP, Wang C-Y. Direct numerical simulation modeling of bilayer cathode catalyst layers in polymer electrolyte fuel cells. J Electrochem Soc 2007;154(11):B1121-31.

[130] Wang Y, Feng X. Analysis of reaction rates in the cathode electrode of polymer electrolyte fuel cell I. Single-layer electrodes. J Electrochem Soc 2008;155(12):B1289-95. 
[131] Wang G, Mukherjee PP, Wang C-Y. Direct numerical simulation (DNS) modeling of PEFC electrodes: Part I. Regular microstructure. Electrochim Acta 2006;51(15):3139-50

[132] Wang G, Mukherjee PP, Wang C-Y. Direct numerical simulation (DNS) modeling of PEFC electrodes: Part II. Random microstructure. Electrochim Acta 2006;51(15):3151-60.

[133] Mukherjee PP, Wang C-Y. Stochastic microstructure reconstruction and direct numerical simulation of the PEFC catalyst layer. J Electrochem Soc 2006;153(5):A840-9.

[134] Song D et al. Numerical study of PEM fuel cell cathode with non-uniform catalyst layer. Electrochim Acta 2004;50(2-3):731-7.

[135] Wang Y, Feng X. Analysis of the reaction rates in the cathode electrode of polymer electrolyte fuel cells. J Electrochem Soc 2009;156(3):B403-9.

[136] Yoon YG et al. A multi-layer structured cathode for the PEMFC. J Power Sources 2003;118(1-2):189-92.

[137] Ferreira $\mathrm{PJ}$ et al. Instability of $\mathrm{Pt} / \mathrm{C}$ electrocatalysts in proton exchange membrane fuel cells. J Electrochem Soc 2005;152(11):A2256-71.

[138] Borup RL et al. PEM fuel cell electrocatalyst durability measurements. J Power Sources 2006;163(1):76-81.

[139] Yasuda $\mathrm{K}$ et al. Platinum dissolution and deposition in the polymer electrolyte membrane of a PEM fuel cell as studied by potential cycling Phys Chem Chem Phys 2006;8:746-52.

[140] Kim L et al. Dissolution and migration of platinum after long-term operation of a polymer electrolyte fuel cell under various conditions. J Power Sources 2008;183(2):524-32.

[141] Yasuda K et al. Characteristics of a platinum black catalyst layer with regard to platinum dissolution phenomena in a membrane electrode assembly. J Electrochem Soc 2006;153(8):A1599-603.

[142] Wang X, Kumar R, Myers DJ. Effect of voltage on platinum dissolution. Electrochem Solid-State Lett 2006;9(5):A225-7.

[143] Akita T et al. Analytical TEM study of Pt particle deposition in the protonexchange membrane of a membrane-electrode-assembly. J Power Sources 2006;159(1):461-7.

[144] Garzon F et al. The impact of hydrogen fuel contaminates on long-term PMFC performance. ECS Trans 2006;3(1):695-703.

[145] Zhang S et al. A review of platinum-based catalyst layer degradation in proton exchange membrane fuel cells. J Power Sources 2009;194(2):588-600.

[146] Uribe FA, Gottesfeld S, Zawodzinski JTA. Effect of ammonia as potential fuel impurity on proton exchange membrane fuel cell performance. J Electrochem Soc 2002;149(3):A293-6.

[147] Zamel N, Li X. Transient analysis of carbon monoxide poisoning and oxygen bleeding in a PEM fuel cell anode catalyst layer. Int J Hydrogen Energy 2008;33(4):1335-44.

[148] Chen C-H et al. Improvement of CO tolerance of proton exchange membrane fuel cell by an air-bleeding technique. J Fuel Cell Sci Technol 2008;5(1):014501.

[149] Shah AA et al. A transient PEMFC model with CO poisoning and mitigation by $\mathrm{O}_{2}$ bleeding and Ru-containing catalyst. J Power Sources 2007;166(1):1-21.

[150] Franco AA et al. Impact of carbon monoxide on PEFC catalyst carbon support degradation under current-cycled operating conditions. Electrochim Acta 2009;54(22):5267-79.

[151] Wan C-H et al. Novel composite anode with CO "Filter" layers for PEFC. J Power Sources 2006;162(1):41-50.

[152] Siegel NP. Development and validation of a computational model for a proton exchange membrane fuel cell. In: Ph.D. dissertation. Virginia Polytechnic Institute and State University: Blacksburg, VA; 2003.

[153] Siegel NP et al. Single domain PEMFC model based on agglomerate catalyst geometry. J Power Sources 2003;115(1):81-9.

[154] Harvey D. Three-dimensional CFD model for PEFC cathodes: application to serpentine flow fields, in fuel cell research centre. Kingston (Ontario): Queen's University; 2006.

[155] Harvey D, Pharoah JG, Karan K. A comparison of different approaches to modelling the PEMFC catalyst layer. J Power Sources 2008;179(1):209-19.

[156] Marr C, Li X. Composition and performance modelling of catalyst layer in a proton exchange membrane fuel cell. J Power Sources 1999;77(1):17-27.

[157] Schwarz DH, Djilali N. 3D modeling of catalyst layers in PEM fuel cells. J Electrochem Soc 2007;154(11):B1167-78.

[158] Shah AA et al. Transient non-isothermal model of a polymer electrolyte fuel cell. J Power Sources 2007;163(2):793-806.

[159] Mathias $M$ et al. Handbook of fuel cells: fundamentals. In: Vielstich W, Gasteiger H, Lamm A, editors. Technology and applications. John Wiley \& Sons, Ltd.; 2003.

[160] Larminie J, Dicks A. Fuel cell systems explained. John Wiley \& Sons; 2000

[161] Yi JS, Nguyen TV. Multicomponent transport in porous electrodes of proton exchange membrane fuel cells using the interdigitated gas distributors. J Electrochem Soc 1999;146(1):38-45.

[162] Wang Y, Wang C-Y. Simulation of flow and transport phenomena in a polymer electrolyte fuel cell under low-humidity operation. J Power Sources 2005;147(1-2):148-61.

[163] Dutta S, Shimpalee S, Van Zee JW. Three-dimensional numerical simulation of straight channel PEM fuel cells. J Appl Electrochem 2000;30(2):135-46.

[164] Wang Y, Wang C-Y. Modeling polymer electrolyte fuel cells with large density and velocity changes. J Electrochem Soc 2005;152(2):A445-53.

[165] Mazumder S, Cole JV. Rigorous 3-D mathematical modeling of PEM fuel cells. J Electrochem Soc 2003;150(11):A1503-9.
[166] Hwang JJ. Thermal-electrochemical modeling of a proton exchange membrane fuel cell. J Electrochem Soc 2006;153(2):A216-24.

[167] Wang Y, Wang C-Y, Nonisothermal A. Two-phase model for polymer electrolyte fuel cells. J Electrochem Soc 2006;153(6):A1193-200.

[168] Birgersson E, Noponen M, Vynnycky M. Analysis of a two-phase nonisothermal model for a PEFC. J Electrochem Soc 2005;152(5):A1021-34.

[169] Pasaogullari U, Wang CY. Liquid water transport in gas diffusion layer of polymer electrolyte fuel cells. J Electrochem Soc 2004;151(3):A399-406.

[170] Nam JH, Kaviany M. Effective diffusivity and water-saturation distribution in single- and two-layer PEMFC diffusion medium. Int J Heat Mass Transfer 2003;46(24):4595-611.

[171] Meng H, Wang C-Y. Electron transport in PEFCs. J Electrochem Soc 2004;151(3):A358-67.

[172] Ralph TR et al. Low cost electrodes for proton exchange membrane fuel cells. J Electrochem Soc 1997;144(11):3845-57.

[173] Wang Y, Wang CY, Chen KS. Elucidating differences between carbon paper and carbon cloth in polymer electrolyte fuel cells. Electrochim Acta 2007;52(12):3965-75.

[174] Wang Y et al. Stochastic modeling and direct simulation of the diffusion media for polymer electrolyte fuel cells. Int J Heat Mass Transfer 2010;53(56):1128-38.

[175] Schulz VP et al. Numerical evaluation of effective gas diffusivity - saturation dependence of uncompressed and compressed gas diffusion media in PEFCs. ECS Trans 2006;3(1):1069-75.

[176] Sinha PK, Mukherjee PP, Wang C-Y. Impact of GDL structure and wettability on water management in polymer electrolyte fuel cells. J Mater Chem 2007; 17(30):3089-103.

[177] Mukherjee PP, Wang C-Y, Kang Q. Mesoscopic modeling of two-phase behavior and flooding phenomena in polymer electrolyte fuel cells. Electrochim Acta 2009;54(27):6861-75.

[178] Becker J, Schulz V, Wiegmann A. Numerical determination of two-phase material parameters of a gas diffusion layer using tomography images. J Fuel Cell Sci Technol 2008;5(2):021006.

[179] Becker J et al. Determination of material properties of gas diffusion layers: experiments and simulations using phase contrast tomographic microscopy. J Electrochem Soc 2009;156(10):B1175-81.

[180] Benziger J et al. Water flow in the gas diffusion layer of PEM fuel cells. J Membrane Sci 2005;261(1-2):98-106.

[181] Sinha PK, Wang CY. Liquid water transport in a mixed-wet gas diffusion layer of a polymer electrolyte fuel cell. Chem Eng Sci 2008;63(4):1081-91.

[182] Gostick JT et al. Pore network modeling of fibrous gas diffusion layers for polymer electrolyte membrane fuel cells. J Power Sources 2007;173(1):277-90.

[183] Lin G, Nguyen TV. A two-dimensional two-phase model of a PEM fuel cell. J Electrochem Soc 2006;153(2):A372-82.

[184] Pasaogullari U, Wang C-Y. Two-phase modeling and flooding prediction of polymer electrolyte fuel cells. J Electrochem Soc 2005;152(2):A380-90.

[185] Wang Y. Modeling of two-phase transport in the diffusion media of polymer electrolyte fuel cells. J Power Sources 2008;185(1):261-71.

[186] Gostick JT et al. On the role of the microporous layer in PEMFC operation. Electrochem Commun 2009;11(3):576-9.

[187] Weber AZ, Newman J. Effects of microporous layers in polymer electrolyte fuel cells. J Electrochem Soc 2005;152(4):A677-88.

[188] Pasaogullari U, Wang C-Y, Chen KS. Two-phase transport in polymer electrolyte fuel cells with bilayer cathode gas diffusion media. J Electrochem Soc 2005;152(8):A1574-82.

[189] Wang Y, Chen KS. In: Proceedings of the 8th International fuel cell science, engineering \& technology conference, Brooklyn, NY; 2010.

[190] Mukundan R et al. Imaging of water profiles in PEM fuel cells using neutron radiography: effect of operating conditions and GDL composition. ECS Meet Abstracts 2007;702(9):406.

[191] Hickner MA et al. In situ high-resolution neutron radiography of crosssectional liquid water profiles in proton exchange membrane fuel cells. J Electrochem Soc 2008;155(4):B427-34

[192] Kramer D et al. In situ diagnostic of two-phase flow phenomena in polymer electrolyte fuel cells by neutron imaging: Part A. Experimental, data treatment, and quantification. Electrochim Acta 2005;50(13):2603-14.

[193] Lehmann EH, Oberholzer P, Boillat P. Neutron imaging methods for the investigation of energy related materials: fuel cells, batteries, hydrogen storage, and nuclear fuel. In: Mater res soc symp proc; 2010. p. W05-01.

[194] Ji Y, Luo G, Wang C-Y. Computer simulation of liquid water transport at pore level in MPL and GDL and their interface. In: ASME eighth international fuel cell science, engineering \& technology conference, Brooklyn, NY; 2010.

[195] Borup R. FC-35: water transport exploratory studies. In: Energy Do, editor, Hydrogen program review; 2009.

[196] Wang ZH, Wang CY, Chen KS. Two-phase flow and transport in the air cathode of proton exchange membrane fuel cells. J Power Sources 2001;94(1):40-50.

[197] Natarajan D, Nguyen TV. A two-dimensional, two-phase, multicomponent, transient model for the cathode of a proton exchange membrane fuel cell using conventional gas distributors. J Electrochem Soc 2001;148(12):A1324-35.

[198] Mazumder S, Cole JV. Rigorous 3-D mathematical modeling of PEM fuel cells. J Electrochem Soc 2003;150(11):A1510-7.

[199] Leverett MC. Capillary behavior in porous solids. Trans AIME 1941;142:151-69. 
[200] Ohn $\mathrm{H}$ et al. Capillary pressure properties of gas diffusion materials used in PEM fuel cells. ECS Trans 2006;1(6):481-9.

[201] Nguyen TV et al. Measurements of two-phase flow properties of the porous media used in PEM fuel cells. ECS Trans 2006;3(1):415-23.

[202] Fairweather JD et al. A microfluidic approach for measuring capillary pressure in PEMFC gas diffusion layers. Electrochem Commun 2007;9(9):2340-5.

[203] Sole JD, Ellis MW. Determination of the relationship between capillary pressure and saturation in PEMFC gas diffusion media. In: Fuel cell; 2008.

[204] Wood DL, Rulison C, Borup RL. Surface properties of PEMFC gas diffusion layers. J Electrochem Soc 2010;157(2):B195-206.

[205] Wood DL, Borup IRL. Estimation of mass-transport overpotentials during long-term PEMFC operation. J Electrochem Soc 2010;157(8):B1251-62.

[206] Mukherjee PP, Mukundan R, Borup RL. Modeling of durability effect on the flooding behavior in the PEFC gas diffusion layer. In: Proceedings of ASME fuel cell 2010, 8th ASME international fuel cell science, engineering, and technology conference; 2010.

[207] Wilkinson DP, Vanderleeden O. Handbook of fuel cells: fundamentals. In: Vielstich W, Gasteiger H, Lamm A, editors. Technology and applications. John Wiley \& Sons, Ltd.; 2003 [chapter 27].

[208] EG\&G Technical Services I. Fuel cell handbook, vol. 7. 2004: US Department of Energy, Office of Fossil Energy, National Energy Technology Laboratory.

[209] Li X, Sabir I. Review of bipolar plates in PEM fuel cells: flow-field designs. Int J Hydrogen Energy 2005;30(4):359-71.

[210] Jiang F et al. Simulation of a PEMFC with zigzag flow field. In: ASME eighth international fuel cell science, engineering \& technology conference, Brooklyn, NY; 2010

[211] Jeon DH et al. The effect of serpentine flow-field designs on PEM fuel cell performance. Int J Hydrogen Energy 2008;33(3):1052-66.

[212] Karvonen $S$ et al. Modeling of flow field in polymer electrolyte membrane fuel cell. J Power Sources 2006;161(2):876-84.

[213] Perng S-W et al. Numerical predictions of a PEM fuel cell performance enhancement by a rectangular cylinder installed transversely in the flow channel. Appl Energy 2009;86(9):1541-54.

[214] Perng S-W, Wu H-W. Non-isothermal transport phenomenon and cell performance of a cathodic PEM fuel cell with a baffle plate in a tapered channel. Appl Energy 2010;88(1):52-67.

[215] Inoue G, Matsukuma Y, Minemoto M. Effect of gas channel depth on current density distribution of polymer electrolyte fuel cell by numerical analysis including gas flow through gas diffusion layer. J Power Sources 2006;157(1):136-52.

[216] Wang Y. Porous-media flow fields for polymer electrolyte fuel cells. J Electrochem Soc 2009;156(10):B1134-41.

[217] Wang X-D et al. Channel aspect ratio effect for serpentine proton exchange membrane fuel cell: role of sub-rib convection. J Power Sources 2009;193(2):684-90.

[218] Yang XG et al. Visualization of liquid water transport in a PEFC. Electrochem Solid-State Lett 2004;7(11):A408-11.

[219] Zhang FY, Yang XG, Wang CY. Liquid water removal from a polymer electrolyte fuel cell. J Electrochem Soc 2006;153(2):A225-32.

[220] Bazylak A. Liquid water visualization in PEM fuel cells: a review. Int J Hydrogen Energy 2009;34(9):3845-57.

[221] Tüber K, Pócza D, Hebling C. Visualization of water buildup in the cathode of a transparent PEM fuel cell. J Power Sources 2003;124(2):403-14.

[222] Basu S, Li J, Wang C-Y. Two-phase flow and maldistribution in gas channels of a polymer electrolyte fuel cell. J Power Sources 2009;187(2):431-43.

[223] Basu S, Wang C-Y, Chen KS. Two-phase flow maldistribution and mitigation in polymer electrolyte fuel cells. J Fuel Cell Sci Technol 2009;6(3):031007.

[224] Jiao K, Zhou B, Quan P. Liquid water transport in straight micro-parallelchannels with manifolds for PEM fuel cell cathode. J Power Sources 2006;157(1):226-43.

[225] Zhu X, Sui PC, Djilali N. Three-dimensional numerical simulations of water droplet dynamics in a PEMFC gas channel. J Power Sources 2008;181(1):101-15.

[226] Quan P et al. Water behavior in serpentine micro-channel for proton exchange membrane fuel cell cathode. J Power Sources 2005;152:31-145.

[227] Hao L, Cheng P. Lattice Boltzmann simulations of anisotropic permeabilities in carbon paper gas diffusion layers. J Power Sources 2009;186(1):104-14.

[228] Adrianowycz OL. Next generation bipolar plates for automotive PEM fuel cells. In: DOE 2009 annual progress report V. Fuel cells, GrafTech International Ltd.; 2009

[229] Fleury E et al. Fe-based amorphous alloys as bipolar plates for PEM fuel cell. J Power Sources 2006;159(1):34-7.

[230] Wang Y, Northwood DO. An investigation into TiN-coated 316L stainless steel as a bipolar plate material for PEM fuel cells. J Power Sources 2007;165(1):293-8.

[231] Wang Y, Northwood DO. An investigation into polypyrrole-coated 316L stainless steel as a bipolar plate material for PEM fuel cells. J Power Sources 2006;163(1):500-8.

[232] Wang Y, Northwood DO. An investigation of the electrochemical properties of PVD TiN-coated SS410 in simulated PEM fuel cell environments. Int J Hydrogen Energy 2007;32(7):895-902.

[233] Silva RF et al. Surface conductivity and stability of metallic bipolar plate materials for polymer electrolyte fuel cells. Electrochim Acta 2006;51(17):3592-8.
[234] Huang JH, Baird DG, McGrath JE. Development of fuel cell bipolar plates from graphite filled wet-lay thermoplastic composite materials. J Power Sources 2005;150:110-9.

[235] Wolf H, Willert-Porada M. Electrically conductive LCP-carbon composite with low carbon content for bipolar plate application in polymer electrolyte membrane fuel cell. J Power Sources 2006;153(1):41-6.

[236] Yen TJ et al. A micro methanol fuel cell operating at near room temperature. Appl Phys Lett 2003;83(19):4056-8.

[237] Brady M. Nitrided metallic bipolar plates. In: DOE 2009 annual progress report V. Fuel cells, Oak Ridge National Laboratory; 2009.

[238] Brady MP et al. Preferential thermal nitridation to form pin-hole free $\mathrm{Cr}$ nitrides to protect proton exchange membrane fuel cell metallic bipolar plates. Scripta Mater 2004;50(7):1017-22.

[239] Brady MP et al. Growth of Cr-Nitrides on commercial $\mathrm{Ni}-\mathrm{Cr}$ and $\mathrm{Fe}-\mathrm{Cr}$ base alloys to protect PEMFC bipolar plates. Int J Hydrogen Energy 2007;32(16):3778-88.

[240] Wang Y, Wang C-Y. Ultra large-scale simulation of polymer electrolyte fuel cells. J Power Sources 2006;153(1):130-5.

[241] Yu SH et al. Numerical study to examine the performance of multi-pass serpentine flow-fields for cooling plates in polymer electrolyte membrane fuel cells. J Power Sources 2009;194(2):697-703.

242] Inoue $G$ et al. Numerical analysis of relative humidity distribution in polyme electrolyte fuel cell stack including cooling water. J Power Sources 2006;162(1):81-93.

[243] Spernjak D, Prasad AK, Advani SG. Experimental investigation of liquid water formation and transport in a transparent single-serpentine PEM fuel cell. J Power Sources 2007;170(2):334-44.

[244] Jiao K, Park J, Li X. Experimental investigations on liquid water removal from the gas diffusion layer by reactant flow in a PEM fuel cell. Appl Energy 2010;87(9):2770-7.

[245] Chen KS, Hickner MA, Noble DR. Simplified models for predicting the onset of liquid water droplet instability at the gas diffusion layer/gas flow channel interface. Int J Energy Res 2005;29(12):1113-32.

[246] He G et al. A two-fluid model for two-phase flow in PEMFCs. J Power Sources 2007;163(2):864-73.

[247] Zhan Z et al. Characteristics of droplet and film water motion in the flow channels of polymer electrolyte membrane fuel cells. J Power Sources 2006;160(1):1-9.

[248] Cai YH et al. Effects of hydrophilic/hydrophobic properties on the water behavior in the micro-channels of a proton exchange membrane fuel cell. J Power Sources 2006;161(2):843-8.

[249] Park JW, Jiao K, Li X. Numerical investigations on liquid water removal from the porous gas diffusion layer by reactant flow. Appl Energy 2010;87(7):2180-6.

[250] Meng H, Wang C-Y. Model of two-phase flow and flooding dynamics in polymer electrolyte fuel cells. J Electrochem Soc 2005;152(9):A1733-41.

[251] Chen KS. Modeling water-droplet detachment from GDL/channel interface in PEM fuel cells. In: Fuel cell 2008 sixth international conference on fuel cell science, engineering and technology, Denver, Colorado; 2008.

[252] Promislow K, Wetton B. A simple, mathematical model of thermal coupling in fuel cell stacks. J Power Sources 2005;150:129-35.

[253] Kim GS et al. Electrical coupling in proton exchange membrane fuel cel stacks. J Power Sources 2005;152:210-7.

[254] Berg P et al. Electrical coupling in proton exchange membrane fuel cell stacks: mathematical and computational modelling. IMA J Appl Math 2006;71(2):241-61.

255] Karimi G, Baschuk JJ, Li X. Performance analysis and optimization of PEM fue cell stacks using flow network approach. J Power Sources 2005;147(12):162-77.

[256] Baschuk JJ, Li X. Mathematical model of a PEM fuel cell incorporating CO poisoning and $\mathrm{O}_{2}$ (air) bleeding. Int $\mathrm{J}$ Global Energy Issues 2003:20(3):245-76.

[257] Chang PAC et al. Flow distribution in proton exchange membrane fuel cel stacks. J Power Sources 2006;162(1):340-55.

[258] Park J, Li X. Effect of flow and temperature distribution on the performance of a PEM fuel cell stack. J Power Sources 2006;162(1):444-59.

[259] Yu X, Zhou B, Sobiesiak A. Water and thermal management for Ballard PEM fuel cell stack. J Power Sources 2005;147(1-2):184-95.

[260] Chen C-H, Jung S-P, Yen S-C. Flow distribution in the manifold of PEM fuel cell stack. J Power Sources 2007;173(1):249-63.

[261] Chang $P$ et al. Reduced dimensional computational models of polyme electrolyte membrane fuel cell stacks. J Computat Phys 2007;223(2):797-821.

[262] DOE-EERE. FCT fuel cells: types of fuel cells; $2009<$ https:// www1.eere.energy.gov/hydrogenandfuelcells/fuelcells/fc types.html> [05.28.10].

[263] Adamson K-A. In: Today FC, editor. 2008 Large stationary survey; 2008.

[264] Google. Google image search: fuel cell vehicles. $2010<$ http://www.google com/images?hl=en\&q=Fuel \pm cell \pm vehicles\&um=1\&ie=UTF-8\&source=univ\&ei $=$ cMBVTPfIK5GWsgOt5LTaAg\&sa=X\&oi=image_result_group\&ct=title\&resnum= 11 \&ved=0CFwQsAQwCg\&biw $=1400 \&$ bih=855>.

[265] Honda. Honda fuel cell power FCX; December 2004. <http://world.honda. com/FuelCell/FCX/FCXPK.pdf> [02.12.10].

[266] Global-hydrogen-bus-platform.com. HyFLEET: about: history: CUTE. <http:/ www.global-hydrogen-bus-platform.com/About/History/CUTE> [02.12.10]. 
[267] DaimlerChrysler. More fuel cell citaros, this time in China and Australia; 2005. <http://www.oxford-chiltern-bus-page.co.uk/130205.htm>.

[268] Hsieh S-S et al. SU-8 flow field plates for a micro PEMFC. J Solid State Electrochem 2005;9(3):121-31.

[269] H-CELL 2.0 Hybrid hydrogen fuel cell power kit: Q\&A FACT SHEET, Horizon fuel cell technologies; 2009.

[270] Wang Y, Tran T. Private Commun 2010

[271] Plug-Power. Image of GenSys system. <http://www.plugpower.com/ products/remoteprimegensys/remoteprimegensys.aspx>.

[272] NIST. PEM Fuel Cells. 2006. <http://www.physics.nist.gov/MajResFac/NIF/ pemFuelCells.html>.

[273] Shimpalee $S$ et al. Predicting water and current distributions in a commercial-size PEMFC. J Power Sources 2004;135(1-2):79-87.

[274] Springer TE, Wilson MS, Gottesfeld S. Modeling and experimental diagnostics in polymer electrolyte fuel cells. J Electrochem Soc 1993:140(12):3513-26.

[275] Zawodzinski TA et al. Determination of water diffusion coefficients in perfluorosulfonate ionomeric membranes. J Phys Chem 1991;95:6040-4.

[276] Hinatsu JT, Mizuhata M, Takenaka H. Water uptake of perfluorosulfonic acid membranes from liquid water and water vapor. J Electrochem Soc 1994;141(6):1493-8.

[277] Chen J, Wang Y, Mukherjee PP. One dimensional analysis of subzero start-up for polymer electrolyte fuel cells. ECS Trans 2008;16(2):273-84.

[278] Kim SH, Pitsch H. Reconstruction and effective transport properties of the catalyst layer in PEM fuel cells. J Electrochem Soc 2009;156(6):B673-81.

[279] Djilali N, Sui PC. Transport phenomena in fuel cells: from microscale to macroscale. Int J Comput Fluid Dyn 2008;22(1-2):115-33.

[280] Williams MV et al. Characterization of gas diffusion layers for PEMFC. J Electrochem Soc 2004;151(8):A1173-80.

[281] Schulz VP et al. Modeling of two-phase behavior in the gas diffusion medium of PEFCs via full morphology approach. J Electrochem Soc 2007;154(4):B419-26.

[282] Wang Y et al. Stochastic modeling and direct simulation of the diffusion media for polymer electrolyte fuel cells. Int J Heat Mass Transfer 2010;53(56):1128-38

[283] Hao L, Cheng P. Lattice Boltzmann simulations of water transport in gas diffusion layer of a polymer electrolyte membrane fuel cell. J Power Sources 2010;195(12):3870-81.
[284] Wang Y. Porous-media flow fields for polymer electrolyte fuel cells. J Electrochem Soc 2009;156(10):B1124-33.

[285] NREL, Photographic information exchange \#12508, 12508.jpg, Editor, National Renewable Energy Laboratory.

[286] Honda. Honda FCX clarity official web site; $2007 . \quad<$ http:// www.automobiles.honda.com/fcx-clarity>.

[287] GM. GM: technology: fuel cell fact sheets; 2010. <http://www.gm.com/ experience/technology/fuel_cells/fact_sheets/> [02.02.10].

[288] Toyota. Toyota sustainable mobility - FCHV-adv; 2010 . <http:// www.sustainablemobility.com/?section=vehicles\&sub=fchv> [02.12.10]

[289] Toyota, Toyota 2007 North American Environmental Report, Toyota, 2007. Energy and Climate Section, p. 9.

[290] Toyota. Toyota FCHV acquires vehicle type certification; 2005. <http:// www.worldcarfans.com/10506178923/toyota-fchv-acquires-vehicle-typecertification> [02.12.10]

[291] McCausland, E. Autoshows: 2009Kia Borrego FCEV Fuel Cell Vehicle; 2008. $<$ http://www.automobilemag.com/auto_shows/2008_los_angeles/ 0811_kia_borrego_fcev_fuel_cell_vehicle/index.html>.

[292] Daimler. Mercedes-Benz B-Class F-CELL: First electric car fully suited for everyday driving and with the driving dynamics of a two-litre petrol car; 2009. <http://media.daimler.com/dcmedia/0-921-1258086-1-1258427-1-00-0-0-1-11702-854934-0-1-0-0-0-0-0.html?TS=1270254293953>.

[293] Fung D, Cunnigham W. Volkswagen Passat Ling Yu Fuel Cell; $2009<$ <ttp:// www.cnet.com.au/volkswagen-passat-ling-yu-fuel-cell-339296693.htm>.

[294] Fuel cell vehicles (from Auto Manufacturers). Fuel cells; 2000. <http:// www.fuelcells.org/info/charts/carchart.pdf>.

[295] Global-hydrogen-bus-platform.com. HyFLEET: CUTE: technology: buses. <http://www.global-hydrogen-bus-platform.com/Technology/Buses> [02.12.10].

[296] Plug-Power. GenSys Specifications Sheet. <http://www.plugpower.com/ userfiles/file/GenSys\%20spec\%20sheet\%20customer\%20\%20email\%282\%29.pdf> [02.12.10].

[297] Baschuk JJ, Li X. A comprehensive, consistent and systematic mathematical model of PEM fuel cells. Appl Energy 2009;86(2):181-93. 